\title{
Improving Financial Statement Footnotes: Evidence from Derivative and Hedging Disclosures
}

by

\author{
Thomas D. Steffen \\ Business Administration \\ Duke University
}

Date:

Approved:

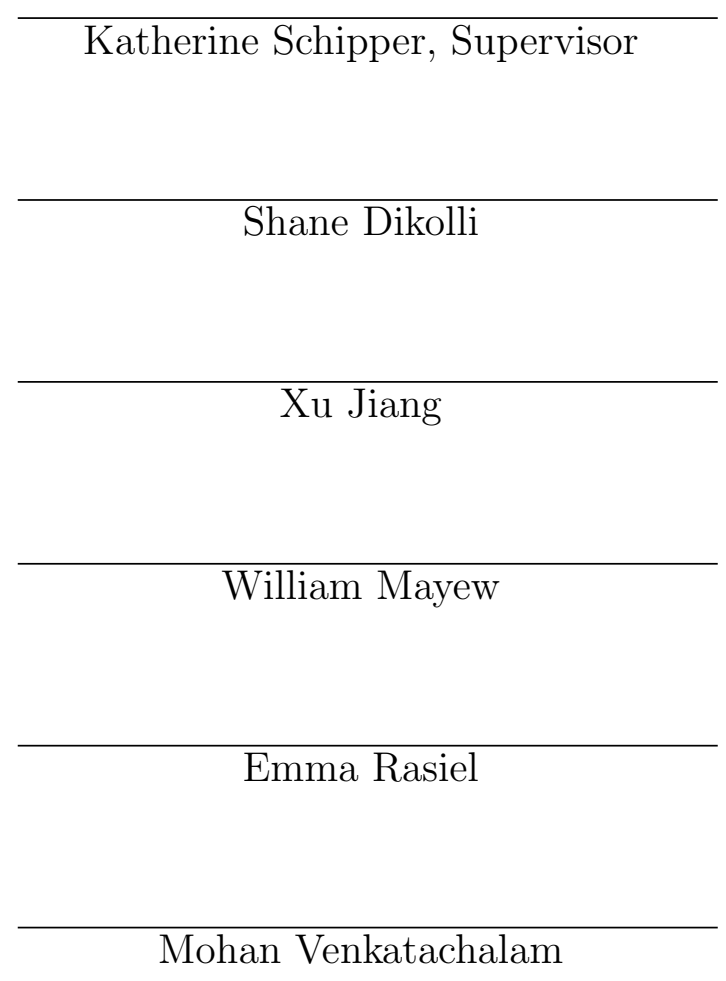

Mohan Venkatachalam

Dissertation submitted in partial fulfillment of the requirements for the degree of Doctor of Philosophy in Business Administration in the Graduate School of Duke University 2015 


\section{ABSTRACT \\ Improving Financial Statement Footnotes: \\ Evidence from Derivative and Hedging Disclosures \\ by}

Thomas D. Steffen

Business Administration

Duke University

Date:

Approved:

\begin{tabular}{c}
\hline Katherine Schipper, Supervisor \\
\hline Shane Dikolli \\
\hline Xu Jiang \\
\hline William Mayew \\
\hline Emma Rasiel
\end{tabular}

Mohan Venkatachalam

An abstract of a dissertation submitted in partial fulfillment of the requirements for the degree of Doctor of Philosophy in Business Administration in the Graduate School of Duke University 2015 
Copyright (C) 2015 by Thomas D. Steffen All rights reserved except the rights granted by the Creative Commons Attribution-Noncommercial Licence 


\section{Abstract}

I investigate whether changes in derivative and hedging footnote disclosures required by SFAS 161 affect investor and analyst uncertainty. My study is motivated by accounting standard setters' and researchers' interest in disclosure effectiveness, and by prior research linking investors' interpretations of public information to measures of uncertainty. For a broad sample of firms, I use textual analysis to measure changes in the amount and salience of derivative and hedging information caused by SFAS 161. Using a difference-in-differences design to study the effects of these changes, I find that investor uncertainty is reduced for firms adopting SFAS 161. In addition, I find that for some uncertainty proxies this reduction is greater for firms whose disclosures were more affected by SFAS 161, consistent with the new disclosures improving investor understanding. I also find evidence of a decreased association between bid-ask spread and movements in risk factors, indicating that SFAS 161 reduced uncertainty stemming from these movements. 
I dedicate this work to my wife, Emily, and to my parents, John and Stephanie Steffen. Their support and encouragement have been invaluable. 


\section{Contents}

Abstract iv

List of Tables viii

List of Figures $\quad$ ix

Acknowledgements $\quad x$

1 Introduction 1

$\begin{array}{lll}2 & \text { Prior research and hypotheses } & 7\end{array}$

2.1 SFAS 161 disclosures $\ldots \ldots \ldots \ldots \ldots \ldots$

$2.1 .1 \quad$ New disclosures . . . . . . . . . . . . . . . . . 8

2.1.2 Disaggregated disclosures . . . . . . . . . . . . . 8

2.1.3 Disclosure frequency, display, grouping, and flexibility . . . . 9

2.2 Prior research . . . . . . . . . . . . . . . . . . . 9

2.2.1 Determinants and effects of derivative use and hedging activities 10

2.2.2 Financial reporting and disclosure for derivatives and hedging 11

2.2 .3 Disclosure characteristics . . . . . . . . . . . . . . . . . . 14

2.3 Hypotheses . . . . . . . . . . . . . . . . . . . 15

3 Research design and sample 20

3.1 Main variables . . . . . . . . . . . . . . . . 20

3.2 Research design . . . . . . . . . . . . . . . . . . . 22

3.2.1 Analyses of disclosure characteristics . . . . . . . . . . 24 
3.3 Sample . . . . . . . . . . . . . . . . . . . . . . . 27

4 Main results $\quad 29$

4.1 Disclosure characteristic measures . . . . . . . . . . . . . . . . . . . . 29

4.2 Tests of hypothesis $1 \ldots \ldots$. . . . . . . . . . . . . . . . 33

4.3 Tests of hypothesis $2 \ldots \ldots \ldots$. . . . . . . . . . . . . . . 35

$\begin{array}{lll}5 & \text { Additional analyses } & 38\end{array}$

5.1 Association of bid-ask spreads and risk-factor fluctuations . . . . . . 38

5.2 MD\&A disclosure characteristics . . . . . . . . . . . . . . . . . . . . . 42

5.3 Regulatory event study . . . . . . . . . . . . . . . . . . . . . . . 43

5.4 Potential changes in risk exposure . . . . . . . . . . . . . . 45

5.5 Effects of risk exposure on main results . . . . . . . . . . . . . 46

5.6 Shifting the period of analysis . . . . . . . . . . . . . 47

5.7 Including only $10-\mathrm{Q}$ filings . . . . . . . . . . . . . . 48

6 Conclusion $\quad 49$

A Summary of SFAS 133 and SFAS 161 disclosure requirements 51

B Variable definitions and dictionary $\quad 55$

$\begin{array}{ll}\mathrm{C} \text { Figures and tables } & 61\end{array}$

$\begin{array}{ll}\text { Bibliography } & 75\end{array}$

$\begin{array}{lr}\text { Biography } & 80\end{array}$ 


\section{List of Tables}

A.1 Summary of SFAS 133 and SFAS 161 disclosure requirements . . . . . 52

B.1 Variable definitions . . . . . . . . . . . . . . . . . . . 55

B.2 Derivative and hedging dictionary . . . . . . . . . . . . . . 59

C.1 Sample description . . . . . . . . . . . . . . . . . . . . . 63

C.2 SFAS 161 textual disclosure measures . . . . . . . . . . . . . 64

C.3 Descriptive statistics for regression variables . . . . . . . . . . 66

C.4 Effect of SFAS 161 on SPREAD and STDRET . . . . . . . . . . 67

C.5 Effect of SFAS 161 on ACCURACY, DISPERSION, UNCTOTAL,

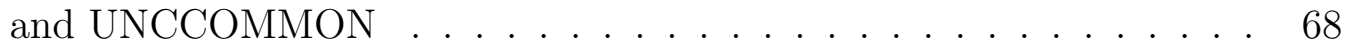

C.6 Effects of SFAS 161 disclosure characteristics on SPREAD and STDRET 69

C.7 Effects of SFAS 161 disclosure characteristics on ACCURACY, DISPERSION, UNCTOTAL, and UNCCOMMON . . . . . . . . . . 71

C.8 Effect of SFAS 161 on the association between SPREAD and risk movements . . . . . . . . . . . . . . . . . 73

C.9 Replication of tables C.6, C.7, and C.8 including MD\&A disclosure characteristics . . . . . . . . . . . . . . . . 74 


\section{List of Figures}

A.1 Pre-SFAS 161 derivative footnote for ConAgra Foods, Inc. . . . . . . 53

A.2 Post-SFAS 161 derivative footnote for ConAgra Foods, Inc. . . . . . . 54

C.1 Research design . . . . . . . . . . . . . . . . . . 62 


\section{Acknowledgements}

I am grateful to my dissertation chair, Katherine Schipper, for her guidance throughout this project. I also appreciate insight from my committee members: Shane Dikolli, Xu Jiang, Bill Mayew, Emma Rasiel, and Mohan Venkatachalam. I am thankful for helpful discussions with William Allen, Alexander Arapoglou, Dirk Black, Nick Cappiello, Qi Chen, Scott Dyreng, Tracy Farr, and my fellow Ph.D. students at Duke University, especially Mani Sethuraman, Zeqiong Huang and Alex Young. I am also grateful for comments received during seminar presentations at Brigham Young University, Emory University, Indiana University, Pennsylvania State University, the University of California Irvine, the University of Oregon, Yale University, and the 2014 AAA/Deloitte/J. Michael Cook Doctoral Consortium. I am also very appreciative of funding provided by Duke University and the Deloitte Foundation. 


\section{Introduction}

In response to financial statement user assertions that the disclosures required by SFAS 133 were not adequate for understanding the effects of firms' derivative use and hedging activities, the Financial Accounting Standards Board (FASB) issued SFAS 161 with the objective of providing "users of financial statements with an enhanced understanding" of the purpose and effects of firms' derivative use and hedging activities (FASB, 2008, paragraph 1, emphasis added). ${ }^{1}$ To evaluate whether SFAS 161 achieved its intended purpose of providing an "enhanced understanding," I examine whether the disclosures required by SFAS 161 affect investor and analyst uncertainty about the value of derivative and hedging firms. I focus on these outcomes because prior theoretical and empirical research suggests that both are affected by the quality of information disclosed in financial reports (e.g., Holthausen and Verrecchia, 1990; Barron et al., 1998; Linsmeier et al., 2002; Lehavy et al., 2011; Bens et al., 2015).

1 FASB Statement No. 133, Accounting for Derivative Instruments and Hedging Activities, was issued in June 1998 and was effective for all fiscal quarters beginning after June 15, 2000. Statement No. 161, Disclosures about Derivative Instruments and Hedging Activities, was issued in March 2008 and was effective for fiscal years and interim periods beginning after November 15, 2008. The accounting and disclosure requirements for derivatives and hedging are now part of Accounting Standards Codification Topic 815. 
Relying on these findings from prior literature and positing that SFAS 161 improved public information related to the objectives and effects of derivatives and hedging, I predict that SFAS 161 reduced investor and analyst uncertainty.

To test these predictions, I use a broad sample of over 2,500 firms and differencein-differences models to document the effect of SFAS 161 on six uncertainty measures calculated after 10-Q and 10-K filing dates during the years immediately before and after the new standard became effective: bid-ask spreads, return volatility, analyst forecast accuracy, analyst forecast dispersion, and measures of total and common analyst uncertainty. I find that firms adopting SFAS 161 experience significant decreases in bid-ask spread, return volatility, and analyst uncertainty; analyst forecast accuracy is also improved as a result of SFAS 161. While these initial analyses test for the existence of an overall SFAS 161 treatment effect, they do not speak to crosssectional variation in the extent to which SFAS 161 changed firms' disclosures and, therefore, investor and analyst uncertainty. Since the reduction in uncertainty from SFAS 161 disclosures should be larger for firms whose disclosures were more affected by the standard, I repeat my analyses after quantifying the effect of SFAS 161 on each sample firm's derivative and hedging disclosures. Specifically, I use custom Perl scripts to measure changes in five characteristics of firms' derivative and hedging 10-K disclosures following the adoption of SFAS 161.

First, since SFAS 161 required new information and changed the structure of derivative and hedging disclosures, I measure the amount of qualitative information by calculating the percentage of all footnote words related to derivatives or hedging. This percentage is based on a custom dictionary of 188 words and phrases derived from a detailed analysis of the derivative and hedging footnotes of 94 firms. Second, because SFAS 161 required more disaggregated fair values, gains, and losses, I measure the amount of quantitative information by counting numbers in sentences and tables related to derivatives or hedging. Third, because SFAS 161 required that 
derivative and hedging disclosures be presented in one footnote or a series of crossreferenced footnotes, I quantify the extent to which qualitative derivative and hedging information is grouped together in the financial statement footnotes. Fourth, I measure the percent of total quantitative derivative and hedging information appearing in tables because SFAS 161 imposed tabular presentation requirements. Fifth, while not addressed by SFAS 161, I calculate the ratio of derivative and hedging words per derivative and hedging number to measure the mix of qualitative and quantitative disclosure. I also combine these variables through factor analysis to capture the overall change in disclosure caused by SFAS $161 .^{2}$

Using these measures, I find that the effects on bid-ask spread, forecast accuracy, and overall analyst uncertainty are more pronounced for firms whose disclosures were more affected by SFAS 161. The disclosure changes that are most consistently associated with reduced uncertainty across these uncertainty proxies are increased qualitative information, more disaggregated quantitative information, and closer grouping of derivative and hedging information. These findings are consistent with improved investor and analyst understanding of the effects of firms' derivative and hedging activity brought about by SFAS 161 disclosures.

I also investigate whether the new disclosures affect the association between bidask spreads and movements in firms' underlying risk factors. Based on reasoning that the new disclosures are meant to improve understanding about how firms use derivatives and hedging to address their risk exposures, I hypothesize and find that the association between bid-ask spreads and risk-factor movements decreases after the adoption of SFAS 161. Using the Perl-derived measures described above, I also find that the decrease is larger for firms whose disclosures were more affected by the new disclosure requirements.

My study is motivated by accounting standard setters' emphasis on the effective-

\footnotetext{
${ }^{2}$ I describe the requirements of SFAS 161 in Section 2.
} 
ness of financial reporting disclosures. The FASB's Disclosure Framework project aims to provide a unifying purpose for financial statement footnotes and to improve the effectiveness of footnote disclosures by communicating and coordinating the information that is most important to financial statement users (FASB, 2012). Similarly, the International Accounting Standards Board believes disclosures should be developed with the goal of effectively communicating the most relevant information in financial reports (IASB, 2013). ${ }^{3}$ In addition, on November 5, 2014, the FASB added a hedge accounting project to its active agenda, and hedging disclosures are among the topics to be considered (Burkholder, 2014).

The adoption of SFAS 161 is a potentially powerful research setting for studying the effects of disclosures for three reasons. First, financial statement users should be concerned with firms' use of derivatives and hedging because they are material to firm values and risk exposures (e.g., Pérez-González and Yun, 2013; Guay, 1999; Schrand, 1997). Second, SFAS 161 was issued as a result of complaints about the inadequacy of existing derivative and hedging disclosures, indicating that financial statement users pay attention to these disclosures. While other complex financial statement components like defined-benefit pensions and income taxes might also meet these first two criteria (e.g., SFAS 132 and 132R address user concerns about pension disclosures), derivatives are noteworthy because they have become more widespread and more complex over time (FASB, 2008; Hull, 2012). ${ }^{4}$ As a result, financial statement users have greater need for, and possibly greater difficulty, understanding derivative instruments and related activities. ${ }^{5}$ In addition, recent legislation has focused on

${ }^{3}$ Paragraphs 7.32-7.52 of the IASB's 2013 Conceptual Framework discussion paper address the content and presentation of footnote disclosures (IASB, 2013).

4 The size of the world's derivative markets illustrates the prominence of these instruments. At the end of 2014 , the total notional value of over-the-counter derivatives was $\$ 630$ trillion, and their gross market value was $\$ 20.9$ trillion (BIS, 2015).

${ }^{5}$ Indeed, Hull (2012) states, "We have now reached the stage where those who work in finance, and many who work outside finance, need to understand how derivatives work, how they are used, 
derivatives (e.g., the Dodd-Frank Act), and these arrangements continue to appear in the business press.

My findings may prove useful to standard setters as they deliberate the characteristics of effective financial statement disclosures in general, and particularly those related to derivatives and hedging. For example, my results suggest that increased amounts of qualitative information, disaggregated quantitative information, and the grouping of similar disclosures have more consistent effects on investor and analyst understanding than improvements to the tabular formatting of information. I also make several contributions to the accounting literature. Because derivative and hedging disclosures are complex and difficult to analyze, most prior research in this area uses hand-collected data to study relatively small samples or focuses on certain industries. This approach provides insight in specific circumstances, but SFAS 161 "applies to all entities" (FASB, 2008, paragraph 2). By creating a large dictionary of derivative and hedging words and phrases and using automated textual analysis, I am able to study a sample of over 2,500 firms representing many industries. The large dictionary allows me to measure with greater precision the amount of derivative and hedging disclosure in financial reports, and I also develop methods to identify the context and presentation format of derivative and hedging information. This approach enables me to measure changes in disclosure features that correspond to particular disclosure changes required by the FASB, and this same approach could be used in future research to examine financial statement disclosures in other contexts. Using these methods, I document the effects of changes in disclosure characteristics on investor and analyst uncertainty, and on the association between bid-ask spread and movements in risk factors.

Section 2 describes the requirements of SFAS 161, summarizes prior research, and presents my hypothesis development. Section 3 describes the research design and and how they are priced" (p. 1, emphasis added). 
sample, and Section 4 presents the main results. Additional analyses are described in Section 5, and Section 6 concludes. 


\section{Prior research and hypotheses}

\subsection{SFAS 161 disclosures}

Before SFAS 161, derivative and hedging footnote disclosures were governed by SFAS 133 and its amendments and interpretations. ${ }^{1}$ Based on feedback from investors and other financial statement users, the FASB determined that the required disclosures were insufficient for comprehending the effects of firms' derivative use and hedging activities (FASB, 2008). As a result, the Board issued SFAS 161 to amend SFAS 133 with the purpose of providing financial statement users with an "enhanced understanding" of firms' derivative use and hedging activities (FASB, 2008, paragraph 1). SFAS 161 required both new disclosures and the disaggregation of previously required quantitative information, and also changed several characteristics of the required disclosures; I describe these changes in the following sections. Appendix A provides a tabular comparison of the SFAS 133 and SFAS 161 disclosure requirements (Table A.1) and an example of derivative disclosures under both standards

${ }^{1}$ As a result of the SEC's Financial Reporting Release No. 48, firms' market risk disclosures also provide information about derivatives and risk exposures (Linsmeier et al., 2002). These disclosures are not part of the financial statement footnotes. I discuss Financial Reporting Release No. 48 in Section 4 . 
(Figures A.1 and A.2). ${ }^{2}$

\subsubsection{New disclosures}

SFAS 161 changed the structure of firms' narrative disclosures about objectives of derivative and hedging activities, from organization by accounting hedge designation (SFAS 133) to organization by underlying risk exposure. ${ }^{3}$ SFAS 161 also requires new disclosures about credit-risk-related contingent features; the events that would trigger the contingencies; and the fair values of any net-liability derivatives containing credit-risk features. The disclosure must also include the fair values of assets that would be used as collateral or to settle the derivative instruments if credit-risk contingencies are triggered. SFAS 161 also requires firms to provide information about the volume of their derivative activity and to indicate which line items on the balance sheet (income statement) contain derivative and hedging fair values (gains and losses).

\subsubsection{Disaggregated disclosures}

Instead of requiring separate fair values only for assets and liabilities (SFAS 133), SFAS 161 mandates that derivative and hedging fair values be presented separately for assets, liabilities, hedging instruments, non-hedging instruments, and each risk exposure category. ${ }^{4}$ Similarly, SFAS 161 increased the level of disaggregation for gains and losses by requiring the disclosure of more than twice the number of separate gains and losses, presented separately for each underlying risk exposure category.

\footnotetext{
2 The remainder of this section discusses the changes caused by SFAS 161; the tabular comparison in Appendix A is structured to facilitate a direct comparison of SFAS 133 and SFAS 161.

3 The Board believed the new structure would "better convey how and why an entity uses derivatives in terms of the risks intended to be managed" (FASB, 2008, paragraph A22).

${ }^{4}$ Hedging instruments are those that (1) qualify for hedge accounting treatment under SFAS 133, and (2) are designated as hedging instruments by management. If an instrument qualifies for hedge accounting treatment, management chooses whether to designate it as a hedging instrument.
} 


\subsubsection{Disclosure frequency, display, grouping, and flexibility}

SFAS 161 increased the frequency of derivative and hedging disclosures, from annual periods only to both interim and annual reporting periods. After considering the cost of preparing these disclosures each quarter, the Board concluded that financial statement users would benefit from interim-period disclosure due to "frequent and often significant changes in derivative fair values" (FASB, 2008, paragraph A50). Firms are also required to use tabular presentation for most quantitative derivative and hedging information, and they must cross-reference their footnotes if derivative and hedging information is presented in more than one footnote. Finally, SFAS 161 provides flexibility to preparers in how to disclose the volume of derivative activity. For example, preparers might disclose derivative notional amounts or the quantity of commodities purchased forward.

As mentioned in Section 1, my study is partly motivated by the FASB's Disclosure Framework project (DFP). Several disclosure changes caused by SFAS 161 are linked to ideas being considered in the DFP. For example, the Board's DFP discussion paper (FASB, 2012) considers the appropriate amount of disclosure (chapter 2); formatting guidelines to improve disclosure effectiveness (paragraphs 5.10 and 5.14); disclosures for interim reporting periods (chapter 6); and flexibility in complying with disclosure requirements (chapter 3).

\subsection{Prior research}

My study of SFAS 161 disclosures builds on and contributes to three areas of prior research that investigate (1) determinants and effects of derivative and hedging activities; (2) financial reporting and disclosure for derivative instruments and related hedging activities; and (3) effects of disclosure characteristics such as presentation format and information grouping. 


\subsubsection{Determinants and effects of derivative use and hedging activities}

Theoretical research on risk management and hedging has identified factors that influence the decision to hedge. Examples include private information, career concerns, risk aversion, and/or price uncertainty (e.g., Holthausen, 1979; Stulz, 1984; DeMarzo and Duffie, 1991, 1995). Similarly, empirical studies find that both managerial characteristics (e.g., experience, stock versus option holdings) and firm characteristics (e.g., block holdings, cash balances, growth opportunities, financial constraints, risk exposure, financial contracting costs) are associated with derivative use and hedging activities (Tufano, 1996; Géczy et al., 1997; Manchiraju et al., 2014). These findings show that many factors affect the decision to hedge and/or use derivatives, which is consistent with the FASB's point of view that improved derivative and hedging disclosures should provide financial statement users with more information about "how and why an entity uses derivatives" (FASB, 2008, paragraph 1).

Other research on the outcomes of derivative use and hedging activities finds that derivative use affects risk exposures (Schrand, 1997; Guay, 1999; Manchiraju et al., 2014) and increases firms' values, investments, and leverage (Allayannis and Weston, 2001; Pérez-González and Yun, 2013). These findings indicate that derivative use and hedging activities affect firms materially, underscoring the need for financial statement users to understand them. Koonce et al. (2008) use an experiment to study how derivative use affects investor perception of managers. They find that the use of non-speculative derivatives to manage risks is perceived favorably by investors, supporting the idea that investors are concerned about "how and why an entity uses derivatives." In a separate experiment, Koonce et al. (2005) show that different descriptions of economically equivalent derivatives and other financial instruments cause investors to make different risk assessments of those derivatives and instruments. In light of the evidence (discussed above) that derivative and hedging 
decisions are influenced by multiple diverse factors, have material effects on firms, and matter to investors, Koonce et al.'s (2005) finding emphasizes the importance of studying how financial statement users are influenced by derivative and hedging disclosures. My study extends this literature by studying how investor and analyst uncertainty are affected by changes to various characteristics of required footnote disclosures for derivatives and hedging activities.

\subsubsection{Financial reporting and disclosure for derivatives and hedging}

Accounting standard setters have periodically reconsidered financial reporting and disclosure for derivatives and hedging activities for more than two decades, and researchers have studied the usefulness of these standards from several perspectives. ${ }^{5}$ McAnally (1996) studies SFAS 105 disclosures and finds that information about banks' derivatives and off-balance-sheet financial instruments are related to measures of market risk and industry-level risk. Similarly, Ahmed et al. (2011) investigate the effects of SFAS 133 and find that the standard reduced banks' cost of capital and resulted in more risk-relevant derivative information for banks' bond investors. Venkatachalam (1996) provides evidence about derivatives' value-relevance by documenting an association between SFAS 119 derivative fair value disclosures and banks' share prices. ${ }^{6}$ Ahmed et al. (2006) also study the value-relevance of banks' derivative disclosures. Using the adoption of SFAS 133 to distinguish between recognized

${ }^{5}$ In 1990, the FASB issued SFAS 105, which required disclosure of notional amounts and other information about certain financial instruments, including derivatives. SFAS 107 (issued in 1991) required disclosure of fair values of financial instruments. SFAS 119 was issued in 1994 to provide more detailed information about derivatives, hedging, and trading activities. SFAS 133, issued in 1998, required all derivative instruments to be recognized at fair value on the balance sheet and specified different accounting treatments, depending on management's intent for the derivative. In addition to the SFAS 161 amendments discussed in Section 2.1, SFAS 133 was amended by SFAS 138, 149, and 155 to clarify definitions and reporting requirements. The FASB is currently re-examining certain aspects of hedge accounting, including disclosures (Burkholder, 2014).

${ }^{6}$ Barth et al. (1996), Eccher et al. (1996), and Nelson (1996) study SFAS 107 financial instrument disclosures, but because of ambiguities in those disclosures, they do not provide direct evidence about derivatives. 
and disclosed derivatives, they find that banks' market values are associated with recognized derivative fair values, but not with disclosed derivative fair values.

Prior research also examines whether derivative and hedging disclosures are useful for evaluating firms' risk exposures. ${ }^{7}$ Linsmeier et al. (2002) argue that investor uncertainty and opinion diversity decreased after the SEC's Financial Reporting Release No. 48 required firms to disclose information about market risks, derivatives, and hedging in the MD\&A section of their filings. Consistent with expectations, they find that trading volume becomes less sensitive to underlying market risk movements after firms begin disclosing this information. On the other hand, Wong (2000) finds weak and mixed evidence of SFAS 119 derivative disclosures' usefulness for assessing firms' risk exposures. Explaining his findings, Wong (2000) states, "Improving disclosures about firms' inherent business risks will increase the usefulness of derivatives disclosures by providing information about the risks being managed with derivatives" (p. 389). He also argues that more disaggregated derivative disclosures would increase their usefulness. More recently, Zou (2012) studies SFAS 133 disclosures and finds that competition increases for airlines with more transparent fuel hedging disclosures because competitors can discern whether the firm will have higher production costs in the future. She also finds that this pattern is stronger after the adoption of SFAS 161. ${ }^{8}$ While these findings support the view that improved derivative and hedging disclosures allow financial statement users to make better assessments of firms' risk exposures, it is unclear whether this only holds for experienced users from the same industry.

In addition to studying derivative and hedging disclosure, prior research also

${ }^{7}$ Another stream of research studies the effects of risk-related disclosures not specific to derivatives and hedging. These papers find that risk disclosures are useful sources of information and are associated with investor perceptions of firm risk (Kravet and Muslu, 2013; Campbell et al., 2014; Bao and Datta, 2014; Hope et al., 2015; Filzen, 2015).

${ }^{8}$ Zou (2012) does not study the specific changes in disclosure brought about by SFAS 161. 
investigates the effects of hedge accounting rules that require derivatives to be recognized at fair value on the balance sheet and permit different accounting treatments depending on whether derivatives are used for hedging purposes. Zhang (2009) studies firms starting to use derivatives and classifies firms as either effective hedgers or speculators. Based on her findings that the adoption of SFAS 133 resulted in decreased risk exposure and cash flow volatility for speculator firms, but not for effective hedger firms, she concludes that "SFAS 133 has discouraged firms from engaging in speculative activities" (p. 246). ${ }^{9}$ For a sample of FTSE 350 firms, Panaretou et al. (2013) find that hedge accounting under IFRS reduces information asymmetry, resulting in lower analyst forecast errors, forecast dispersion, and bid-ask spreads. Pierce (2015) hand-collects data from SFAS 161 disclosures to study the effects of hedge accounting choices and finds that hedge accounting decreases earnings volatility and is positively associated with firm value. Cowins (2014) also manually examines SFAS 161 disclosures and concludes that existing hedge accounting requirements are useful for distinguishing hedging firms from speculating firms.

The weight of the evidence from these studies suggests that derivative and hedging disclosures are useful to market participants, and I extend this literature in two ways. First, due to the complex nature of these disclosures and the reliance on handcollected data, the extant literature uses relatively small samples and/or focuses on specific industries. ${ }^{10}$ Using textual analysis methods allows me to examine derivative and hedging disclosures for a large sample of 2,631 firms spanning many industries. Second, my study expands the SFAS 161 literature that so far has focused primarily

${ }^{9}$ Because SFAS 133 introduced new standards for both recognition and disclosure, it is difficult to conclude whether one or both are driving Zhang's (2009) findings.

10 For example, McAnally (1996) averages 166 banks per year; Ahmed et al. (2011) use 141 banks; Venkatachalam (1996) studies 99 banks; Ahmed et al. (2006) analyze 146 banks; Linsmeier et al. (2002) study 222 large, non-financial firms; Wong (2000) uses 145 manufacturing firms; Zou (2012) only analyzes airlines; Zhang (2009) studies 225 non-financial firms; Panaretou et al. (2013) averages 169 firms per year; Pierce (2015) analyzes 223 non-financial firms; and Cowins (2014) studies 270 non-financial firms. 
on competitors' use of disclosure (Zou, 2012), the effects of hedge accounting, and whether firms use derivatives to hedge or speculate (Pierce, 2015; Cowins, 2014; Manchiraju et al., 2014). By investigating the effects of particular characteristics of derivative and hedging disclosures on investor and analyst uncertainty, I shed light on how financial statement users are affected by the FASB's efforts to improve these disclosures.

\subsubsection{Disclosure characteristics}

My study of SFAS 161 also relates to research on the effects of presentation format, information grouping, and the interplay between qualitative and quantitative information. Mentioned in Section 2.2.1, Koonce et al. (2005) show that investors' risk assessments of derivative and financial instruments are affected by the way the instruments are described. Prior experimental research also finds that presentation format influences financial statement users. Hirst and Hopkins (1998) study the ability of professional analysts to acquire information about comprehensive income. They find that, relative to disclosing comprehensive income in the statement of changes in equity, information acquisition improves when the information is disclosed in a separate statement of comprehensive income. Similarly, Maines and McDaniel (2000) show that non-professional investors' processing of comprehensive income information is improved when the disclosure occurs in a statement of comprehensive income instead of the statement of changes in equity. Rennekamp (2012) also finds that small investors' information processing fluency is affected by presentation format. ${ }^{11}$ Using an archival sample, Linsmeier et al. (2002) find that the effectiveness of market risk disclosure formats depends on the type of risk being evaluated. For market risk dis-

${ }^{11}$ Rennekamp's (2012) study is part of the literature on the SEC's plain English initiative and focuses primarily on disclosure readability (e.g., Li, 2008; Miller, 2010; Lawrence, 2013; Loughran and McDonald, 2014), which is not a specific focus of SFAS 161. However, her experimental manipulation of "readability" includes tabular presentation, which relates directly to SFAS 161. 
closures in the MD\&A, they conclude that tabular display is more useful for assessing interest rate exposure, but sensitivity analyses and value-at-risk disclosures are more effective for evaluating foreign exchange rate exposures.

Bloomfield et al. (2015) use an experiment to show that credit analysts' ability to identify relevant information in financial reports is improved when similar information is grouped in the same section of a financial disclosure. The authors argue that coordinated presentation reduces "the cognitive load necessary for integrating the related information and forming a meaningful mental model of the firm" (p. 525). Relatedly, Allee and DeAngelis' (2015) archival study of conference calls finds that the dispersion of tone words in conference calls is informative about performance. They conclude that "tone dispersion both reflects and affects the information that managers convey through their narratives" (p. 243).

The findings from these papers emphasize the importance of considering the effects of changes to different characteristics of derivative and hedging disclosures brought about by SFAS 161. I extend and complement archival studies of MD\&As and conference calls and related experimental studies, in which the researchers control the disclosures and their characteristics, by applying textual analysis to a broad archival sample, and by simultaneously studying the amount of qualitative and quantitative information, tabular formatting, and grouping of derivative and hedging disclosure within financial statement footnotes.

\subsection{Hypotheses}

I investigate whether SFAS 161 disclosures affect information uncertainty. I focus on this outcome because prior research (discussed below) suggests investor and analyst uncertainty is influenced by the quality of information disclosed in financial reports. In other words, studying uncertainty should provide insight into how well financial statement users understand disclosures. For example, a firm might engage 
in some level of derivative and hedging activity, with the objective of mitigating risk exposures, speculating, or some combination of both. When investors attempt to understand the firm's business model and its future prospects, it is reasonable to assume that their uncertainty about the firm's intrinsic value would be influenced by their ability to understand the purpose of the firm's derivative and hedging activities. Similarly, the uncertainty of analysts forecasting the firm's earnings will be affected by analysts' ability to understand how financial reporting outcomes are impacted by derivatives and hedging. Thus, a shift in disclosure requirements that improves understanding of how the firm's value is affected by derivative and hedging arrangements should correspond to changes in information uncertainty for users of the financial statements. ${ }^{12,13}$

In their examination of the usefulness of the SEC's disclosure monitoring processes, Bens et al. (2015) take a similar point of view. They study the information uncertainty effects for firms receiving SEC comment letters about fair value disclosures. Arguing that the SEC comment letter process "identif[ies] substantial accounting and/or disclosure deficiencies," Bens et al. expect fair value comment letters to reduce information uncertainty because firms are likely to improve fair value disclosures and monitoring of fair value processes after receiving a letter. In other words, fair value information is improved as as result of an external influence on the firm (the SEC comment letter). Bens et al. (2015) study a sample of 1,432 firms receiving a fair value comment letter between 2007 and 2012, and consistent

${ }^{12}$ By focusing on information uncertainty, I assume that a shift in disclosure requirements does not itself change the derivative and hedging behavior of the firm. In other words, I assume that on average, there are no "real effects" on derivative and hedging activity as a result of SFAS 161. I provide support for this assumption in Section 4.

${ }^{13}$ In addition, I focus on uncertainty and not firm value because "an identical asset held or a liability owed by two different entities can have very different implications" for those entities' intrinsic values (FASB, 2014, paragraph D14). Thus, it is not possible to predict how firms' derivative and hedging behavior affects firm value, even if firms are exposed to similar risks. However, uncertainty does not depend on whether firm value is positively or negatively impacted by derivatives and hedging. 
with their predictions, find a decrease in the post-10-K average bid-ask spread and return volatility for firms receiving comment letters. ${ }^{14}$ In the context of analysts, Lehavy et al. (2011) also study the effects of disclosure content on uncertainty. Using a sample of more than 30,000 10-K filings between 1995 and 2006, they show that less readable 10-K filings are associated with reduced forecast accuracy, increased forecast dispersion, and greater analyst uncertainty. ${ }^{15}$

While Bens et al. (2015) and Lehavy et al. (2011) are motivated by questions about the effectiveness of SEC monitoring and the role of information intermediaries, respectively, they offer useful perspectives for approaching the question of whether FASB-mandated disclosure changes are useful to financial statement users. Conceptually, both studies focus on distinguishing disclosure content from firm characteristics in order to shed light on how disclosure itself affects uncertainty of investors and analysts. I take a similar point of view in examining whether disclosure changes required by SFAS 161 reduce uncertainty of financial statement users. In much the same way that an SEC comment letter induces disclosure improvement in the Bens et al. (2015) setting, the mandated adoption of SFAS 161 also marks a shift in disclosure quality. Investigating whether information uncertainty is affected by the new disclosures is an obvious approach because of the FASB's stated purpose of improving understanding of derivative and hedging behavior. In other words, information uncertainty should decrease if the FASB met its objective in issuing SFAS 161. Comment letters from the SFAS 161 exposure draft provide anecdotal support for this point of view. Consider the experience of William Allen, a CPA and CFA with more than 30 years of derivatives experience: "I support the new effort launched last

14 They focus on the post-10-K period because the 10-K contains the fair value disclosures that are likely affected by the comment letter process.

${ }^{15}$ Lehavy et al. (2011) also show associations of 10-K readability with analyst following, analyst effort, and analyst report informativeness. However, I focus on their uncertainty-related outcome measures because SFAS 161 is focused on improving understanding. 
week for additional disclosure to describe better why and how companies are using derivatives for hedging purposes...This weekend I had been asked by a client to try to help them understand just exactly how Liberty Media has used equity derivatives to hedge its positions in or to facilitate its acquisitions of certain equity investments. I spent about 12 hours [poring] through their financial statements and various SEC filings...and...I had to give up. The disclosure was too opaque and imprecise." 16

However, it is not clear that such efforts by the FASB will result in new disclosures that improve investor understanding. Another comment letter addressed to the Board states, "Our feeling [is] that this disclosure is pretty confusing and its value is at issue by most of us in that it makes the financial statements misleading, and therefore without any true benefit to the investor. Creating another layer of confusing and burdensome disclosure is not the answer. Keep in mind you are creating a new disclosure that makes the analysis clearer for you, not the general public." ${ }^{17}$ Chang et al. (2015) study how analyst forecasts are affected when firms begin using derivatives. They find evidence that analysts "routinely misjudge the earnings implications of firms' derivatives activity" due to the financial reporting complexities associated with derivative use (p. 4), and while they conclude that over-time improvements to derivative standards have helped analysts, they do not find that SFAS 161 remedies the effects of derivatives on forecast accuracy and dispersion. Thus, it is possible that the subject matter of derivatives and hedging is simply too complex for any disclosure enhancement to cause an observable decrease in information uncertainty. In addition, the FASB is currently reconsidering derivative and hedging disclosures (Burkholder, 2014). While this could be due to over-time increases in the complexity of derivatives and hedging arrangements, it could also indicate that the disclosure re-

16 See the first comment letter at http://www.fasb.org/jsp/FASB/CommentLetter_C/ CommentLetterPage\&cid $=1218220137090 \&$ project_id $=1510-100$

17 See the second comment letter at http://www.fasb.org/jsp/FASB/CommentLetter_C/ CommentLetterPage\&cid=1218220137090\&project_id=1510-100 
quirements of SFAS 161 did not fully accomplish the objective of enhancing investor understanding.

Notwithstanding the arguments against SFAS 161 causing an observable decrease in information uncertainty, I take the point of view of the FASB and predict that information uncertainty is reduced for firms adopting SFAS 161. In addition, I expect this decrease to be greater for firms whose disclosures improve more as a result of adopting SFAS 161. Stated formally, my hypotheses are:

H1: Information uncertainty decreases after firms adopt SFAS 161.

H2: Information uncertainty decreases more after adoption for firms whose disclosures were more affected by SFAS 161 . 


\section{3}

\section{Research design and sample}

\subsection{Main variables}

To proxy for information uncertainty, I use market-based proxies from Bens et al. (2015) and analyst-based proxies from Lehavy et al. (2011). Bens et al. (2015) use the bid-ask spread and return volatility to proxy for information uncertainty. The bid-ask spread is commonly used to to proxy for information asymmetry and trading frictions (e.g., Leuz and Verrecchia, 2000; Heflin et al., 2015). These factors matter for investors' trading decisions, and they also pertain to the FASB's objective of facilitating investors' resource allocation decisions by providing useful information (FASB, 2010). Return volatility has also been used in prior research to proxy for information uncertainty (e.g., Pastor and Veronesi, 2003; Zhang, 2006; Rajgopal and Venkatachalam, 2011). To construct my market-based proxies, I follow Bens et al. (2015) and define SPREAD as the natural log of the average daily bid-ask spread during the calendar month following a firm's $10-\mathrm{Q}$ or 10-K filing date. Similarly, I define STDRET as the standard deviation of daily returns during the calendar month following a firm's 10-Q or 10-K filing date. This approach is advantageous 
in my setting because the measurement window begins when firms' derivative and hedging disclosures become publicly available. Bens et al. (2015) only include 10-K filing dates in their analyses because they are focused on fair value estimates, and they argue that the 10-K contains "the most comprehensive set of information about fair value estimates and disclosure" (p. 15). However, because SFAS 161 requires the same derivative and hedging disclosures for annual and interim periods, I include 10-Q filing dates in addition to 10-K filing dates.

In examining the analyst information environment, Lehavy et al. (2011) use forecast accuracy, forecast dispersion, and two measures of analyst uncertainty based on results from Barron et al. (1998). Consistent with SPREAD and STDRET, I construct these analyst-based measures immediately after firms' derivative and hedging disclosures become available (i.e., after 10-Q and 10-K filing dates). Following Lehavy et al. (2011), I define $A C C U R A C Y$ as the squared difference between the analyst consensus EPS forecast and the IBES actual EPS, scaled by stock price 90 days prior to the consensus forecast date. ACCURACY is based on forecasts and actual earnings for quarter $t+1$ and is measured on the first consensus forecast date after the $10-\mathrm{Q}$ or $10-\mathrm{K}$ filing date for quarter $t$. In other words, $A C C U R A C Y$ is meant to capture how the information in the $10-\mathrm{Q}$ or $10-\mathrm{K}$ filing influences the accuracy of forecasts for the next fiscal quarter. Similarly, DISPERSION is the standard deviation of the individual forecasts that are used to form the consensus forecast used to calculate $A C C U R A C Y$; the standard deviation is also scaled by stock price 90 days prior to the consensus forecast date. In addition, I follow Lehavy et al. (2011) and use ACCURACY and DISPERSION to construct measures of total and common analyst uncertainty based on the findings of Barron et al. (1998). Specifically, UNCTOTAL $=\left(1-\frac{1}{N}\right) \times D I S P E R S I O N+A C C U R A C Y$, and UNCCOMMON $=\frac{A C C U R A C Y-\frac{D I S P E R S I O N}{N}}{U N C T O T A L}$, where $N$ is the number of individual analysts contributing 
to the consensus. Lehavy et al. (2011) explain that UNCTOTAL captures the sum of analysts' idiosyncratic and common uncertainty, while UNCCOMMON measures the common proportion of analysts' uncertainty. ${ }^{1}$

\subsection{Research design}

To test H1's prediction that the adoption of SFAS 161 results in disclosures that decrease information uncertainty, I examine the six uncertainty proxies (described above) in a difference-in-differences framework. Because SFAS 161 became effective near the end of the 2008 financial crisis, the difference-in-differences approach is important for identifying the effects of the new disclosures separately from timeperiod effects. My tests of $\mathrm{H} 1$ are based on the following baseline model with firm index $i$ and quarter index $t$ :

$$
\begin{aligned}
U N C P R O X Y_{i t} & =\alpha_{0}+\alpha_{1} \text { POST }_{i t}+\alpha_{2} \text { TREAT }_{i}+\alpha_{3} \text { POST }_{i t} \times T R E A T_{i} \\
& +\sum_{k=1}^{k=n} \beta_{1, k} \text { CONTROL }_{k, i t}+\varepsilon_{i t}
\end{aligned}
$$

In this model, UNCPROXY is one of the six uncertainty proxies described in Section 3.1: SPREAD, STDRET, ACCURACY, DISPERSION, UNCTOTAL, or UNCCOMMON. POST is an indicator variable equal to one (zero) for all fiscal quarters with 10-Q or 10-K filing dates on or after (before) the firm's initial SFAS 161 filing. TREAT is an indicator equal to one (zero) for firms (not) affected by SFAS $161 .^{2}$

${ }^{1}$ Lehavy et al. (2011) use only annual earnings forecasts after 10-K filings because they study annual report readability. As mentioned previously, I also include 10-Q filing dates because SFAS 161 disclosures are required for quarterly and annual filings.

${ }^{2}$ As described in more detail in Appendix B, treatment firms are identified as those mentioning SFAS 161 in 10-Q or 10-K filings filed between March 1, 2008 and December 31, 2009 and having at least 10 derivative or hedging words or phrases in their pre-SFAS 161 10-K filing. Manual inspection of this categorization procedure indicates that firms not mentioning SFAS 161 do not use derivatives and are thus not affected by SFAS 161. However, some non-derivative users mention SFAS 161; anecdotally, this occurs when a firm describes all new accounting standards in its SEC filings, even if certain standards do not affect the firm. Under my classification procedure, these firms would be misclassified as treatment firms. The requirement for at least 10 derivative or hedging words is meant to mitigate this risk of misclassification. 
The CONTROL variables included in equation (1) vary depending on which uncertainty proxy is the dependent variable, and they are based on controls included in Bens et al. (2015) and Lehavy et al. (2011). For SPREAD, the control variables are return on assets $(R O A)$, leverage $(L E V)$, book-to-market ratio $(B T M)$, size $(S I Z E)$, average stock price (PRICE), average trading volume (TURNOVER), analyst following (FOLLOW), previous return volatility (PASTSTDRET), and average trade size (TRADESIZE). In addition to these control variables from Bens et al. (2015), I include two-digit SIC fixed effects and PREDERIV, the percentage of words in the pre-SFAS 161 10-K filing related to derivatives and hedging; this proxies for the importance of derivative and hedging activity to the firm. The control variables for the STDRET specification are identical to those for SPREAD except that PASTSTDRET and TRADESIZE are not included.

The control variables for the ACCURACY, DISPERSION, UNCTOTAL, and UNCCOMMON specifications are based on Lehavy et al. (2011) and include market capitalization $(L O G M C A P)$, sales growth $(G R O W T H)$, the number of business segments (LOGSEGMENTS), the percent of institutional shareholders (PINST), the count of management forecasts $(M F C O U N T)$, the two-day cumulative abnormal return starting on the $10-\mathrm{Q}$ or $10-\mathrm{K}$ filing date $(N E W S)$, SG\&A expenses as a percent of operating expenses $(S G A)$, previous return volatility (PASTSTDRET), and two-digit SIC fixed effects. I also include PREDERIV in these four specifications to control for the extent of firms' derivative and hedging activity. ${ }^{3}$

In each specification, $P O S T_{i t} \times T R E A T_{i}$ is the difference-in-differences estimator and captures the effect of SFAS 161 on each uncertainty proxy. Because each of the six uncertainty proxies is defined such that higher values indicate more uncertainty, H1 predicts $\hat{\alpha}_{3}<0$ for each specification.

\footnotetext{
${ }^{3}$ All control variables are described in Appendix B.
} 


\subsubsection{Analyses of disclosure characteristics}

Equation (1) provides a framework for estimating the impact of SFAS 161 on measures of information uncertainty. However, this approach does not allow for crosssectional variation in the extent to which firms' derivative and hedging disclosures were affected by the new requirements. H2 predicts that the decrease in information uncertainty brought about by SFAS 161 should be greater for firms whose disclosures improved more. My tests of $\mathrm{H} 2$ are based on the following modification of equation (1):

$$
\begin{aligned}
U N C P R O X Y_{i t} & =\alpha_{0}+\alpha_{1} \text { POST }_{i t}+\alpha_{2} T R E A T_{i}+\alpha_{3} P O S T_{i t} \times T R E A T_{i} \\
& +\alpha_{4} \operatorname{POST}_{i t} \times T R E A T_{i} \times D I S C V A R_{i} \\
& +\sum_{k=1}^{k=n} \beta_{1, k} C O N T R O L_{k, i t}+\varepsilon_{i t}
\end{aligned}
$$

The only difference between equation (2) and equation (1) is the addition of the $P O S T_{i t} \times T R E A T_{i} \times D I S C V A R_{i}$ interaction term. This variable allows the differencein-differences effect captured by $\alpha_{3}$ to vary cross-sectionally with changes in firms' disclosures (DISCVAR). As described in Section 2.1, SFAS 161 changed various characteristics of firms' derivative and hedging footnote disclosures, and I use custom Perl scripts to create five measures of these disclosure changes. Specifically, I measure the change in each firm's disclosure characteristic (DISCVAR) as the difference between (1) the characteristic from the firm's first 10-K filing footnotes under SFAS 161, and

(2) the characteristic from its last 10-K filing footnotes under SFAS 133 (see Figure C.1).

First, since SFAS 161 required a new structure (disclosure by risk exposure) and new information, I measure the amount of qualitative information as the percentage of all words in the financial statement footnotes related to derivatives and hedging $(W O R D S$ ). This percentage is based on a new dictionary of 188 words and phrases 
derived from a detailed analysis of all words, two-word phrases, and three-word phrases appearing in the derivative and hedging footnote from 94 firms (Appendix B provides the dictionary). This approach greatly expands the set of words and phrases used in prior research to identify derivative and hedging information, thereby increasing the precision of the textual measures. ${ }^{4}$ Second, because SFAS 161 required more disaggregated numerical information, I measure the amount of quantitative information as the count of numbers related to derivatives or hedging (NUMS). Creating this measure requires two steps. The Perl script first parses the footnotes into individual sentences. If a sentence contains any of the 188 dictionary words or phrases, I count the numbers in the sentence. Next, the Perl script utilizes HTML tags in 10-K filings to examine every individual table cell in the footnotes. For table cells containing only numbers, the script then searches all the cells directly above (i.e., column headings) and directly to the left (i.e., row headings) for any derivative or hedging words or phrases. I count all cells containing numbers whose column and/or row headings contain derivative or hedging words or phrases. $N U M S$ is defined as the sum of the counts from these two procedures, multiplied by 100 and scaled by the total number of words in the financial statement footnotes.

Third, because SFAS 161 required derivative and hedging disclosures to be presented in either one footnote or a series of cross-referenced footnotes, I measure the extent to which qualitative derivative and hedging information is grouped together in the footnotes. GROUP is defined as the standard deviation of the scaled locations of the dictionary words and phrases in the footnotes. For example, if a filing's total length is 10 words and the first, second, and fifth words match the dictionary, GROUP is the standard deviation of $\left(\frac{100 \times 1}{10}, \frac{100 \times 2}{10}, \frac{100 \times 5}{10}\right)$. Fourth, since SFAS 161 requires tabular display for quantitative information, I use Perl scripts to measure

${ }^{4}$ For example, Guay (1999) searches for forward contract(s), currency exchange contract(s), foreign exchange contract(s), futures contract(s), option(s) contract(s), rate swap(s), swap agreement(s), hedging instrument(s), and derivative(s) instrument(s). 
the percent of total quantitative derivative and hedging information appearing in tables. TABNUMS is defined as the count of derivative and hedging numbers presented in tables (the second component of NUMS described above) multiplied by 100 and divided by the total count of derivative and hedging numbers. Lastly, I calculate the ratio of qualitative to quantitative derivative and hedging information. WPER$N U M$ is defined as the number of derivative and hedging words or phrases divided by the total count of derivative and hedging numbers. While this ratio is not part of the FASB's disclosure requirements, I include it to examine whether, for example, more quantitative information is being provided without additional qualitative explanations.

Changes in these five measures capture separate disclosure effects of SFAS 161. The FASB's basis for conclusions indicates that the Board viewed each one, except the ratio of words to numbers which is not explicitly mentioned, as an improvement to derivative and hedging disclosures (see paragraphs A1-A77 of FASB, 2008). As a result, I expect each characteristic partially drives the effect of SFAS 161 on information uncertainty, but I do not predict which characteristic(s) might matter most. In addition, as the effect of SFAS 161 may also be driven by a combination of these characteristics, I combine them through factor analysis to measure the overall effect on derivative and hedging disclosures caused by SFAS 161 (DFACTOR). ${ }^{5}$

Thus, DISCVAR in equation (2) can take the value of $\triangle W O R D S, \triangle N U M S$, $\triangle$ GROUP, $\triangle T A B N U M S, \triangle W P E R N U M$, and DFACTOR. ${ }^{6}$ Consistent with H2, I

${ }^{5}$ Appendix B provides details for each disclosure characteristic variable. Because WPERNUM is not a specific disclosure requirement of SFAS 161, I do not include it in the factor analysis (if WPERNUM is included in the factor analysis, the correlation between the resulting retained factor and DFACTOR is 0.9919). The factor analysis yields two factors with eigenvalues greater than one. For the first factor (eigenvalue of 1.90905), NUMS and WORDS load strongest (loadings of 0.8636 and 0.8579 , respectively), followed by TABNUMS (loading of 0.6362) and GROUP (loading of 0.1499). The second factor has an eigenvalue of 1.00071 and loads almost entirely on GROUP (loading of 0.9725). Because the correlation between the second factor and GROUP is 0.9827, I only retain the first factor as DFACTOR.

${ }^{6}$ DFACTOR is not a change variable like the other characteristics because the inputs to the factor 
predict $\hat{\alpha}_{4}<0$ for each of the DISCVAR measures. ${ }^{7}$

\subsection{Sample}

Panel A of Table C.1 describes my initial sample, which is generated by the intersection of the WRDS SEC Analytics Suite, Compustat, and CRSP databases. The WRDS SEC Analytics Suite is used to identify the filing dates of firms' initial SFAS 161 filings. As SFAS 161 is effective for all fiscal years and interim reporting periods beginning after November 15, 2008, I identify adoption periods as either (1) a first, second or third fiscal quarter ending between February 15, 2009 and May 15, 2009; or (2) a first fiscal quarter ending between May 16, 2009 and August 15, 2009. ${ }^{8}$ Sample firms are required to have Compustat and CRSP data, and they must have valid disclosure characteristic variables calculated from their pre- and post-adoption 10-Ks (see Figure C.1).

These sample selection procedures do not exclude firms for any reason other than data availability, resulting in the maximum number of treatment and non-treatment firms in all industries. The final sample available for analysis with my Perl scripts consists of 2,631 firms. Untabulated analyses show that 2,246 (85\%) of the sample firms' initial adoptions occur in the first quarter of fiscal $2009 .{ }^{9}$

analysis are the change variables.

7 For each disclosure variable except $\triangle G R O U P$, more positive values indicate a greater effect of SFAS 161. However, more positive values of $\triangle G R O U P$ indicate less treatment effect (more dispersed information). To maintain the predicted sign of $\hat{\alpha}_{4}$ across the six DISCVAR estimations of equation (2), $\triangle$ GROUP is multiplied by -1 .

8 This procedure ignores early adoption; however, SFAS 161 was issued in March 2008, leaving little time for early adoption before the November 15, 2008 effective date. In addition, an anecdotal examination of filings from this period indicated that very few firms appeared to adopt SFAS 161 before they were required to do so.

9 SFAS 161 disclosure requirements are not different for annual and interim periods. However, I do not use initial 10-Q filings to calculate the disclosure characteristic variables because only $10-\mathrm{K}$ filings contain derivative and hedging footnote disclosures in the pre-period. To keep the basis for disclosure comparison constant from the pre- and post-periods, I use the $10-\mathrm{K}$ from each period to calculate the changes in disclosure characteristics (see Figure C.1). 
Panel B of Table C.1 presents the Fama/French-12 industry distribution of the sample firms separated by SFAS 161 treatment. ${ }^{10}$ The sample contains 1,910 (73\%) treatment firms (defined as firms mentioning SFAS 161 in 10-Q or 10-K filings and having at least 10 derivative and hedging words or phrases in their pre-SFAS 161 $10-\mathrm{K})$ and 721 (27\%) non-treatment firms. Untabulated analyses indicate that treatment firms have more assets (average of $\$ 9.7$ billion) and sales (average of $\$ 761$ million) compared to non-treatment firms (average assets of $\$ 2.4$ billion and average sales of $\$ 339$ million). ${ }^{11}$ All 12 industries are represented in the treatment and non-treatment groups, but the industry composition differs across the groups (Pearson's $\chi^{2}=93.91, p=0.000$, untabulated). However, three of the four most frequent industries for treatment firms are also three of the four most frequent industries for non-treatment firms, and these three industries account for $55 \%$ of all sample firms. This indicates that despite overall differences in industry composition (nontreatment firms appear more concentrated in a few industries), both treatment and non-treatment firms are represented in the most common industries, decreasing the likelihood that my results are driven by factors in certain industries unrelated to SFAS 161. ${ }^{12}$ These three industries are finance (FF-11) with $25.3 \%$ of the sample (e.g., Bank of America and Citigroup); business equipment (FF-6) with 17.8\% (e.g., IBM and Microsoft); and other (FF-12) with 11.6\% (e.g., General Electric and Delta Airlines).

\footnotetext{
10 To classify firms into the Fama-French 12 industries based on SIC code, I use Ed deHaan's code available at http://faculty-gsb.stanford.edu/deHaan/documents/industries_ff12.txt.

11 These differences in means are significant at the $p<0.02$ level for assets and the $p<0.0001$ level for sales. For each firm, the assets and sales are measured for the quarter in which the firm adopted SFAS 161 (see Figure C.1).

${ }^{12} \mathrm{I}$ also include industry fixed effects in all the regression models.
} 


\section{4}

\section{Main results}

\subsection{Disclosure characteristic measures}

Table C.2 presents summary statistics and correlations for the Perl-derived disclosure characteristic measures used to estimate equation (2). ${ }^{1}$ Panel A provides descriptive statistics for $\triangle W O R D S, \triangle N U M S, \triangle G R O U P, \triangle T A B N U M S, \triangle W P E R N U M$, and DFACTOR separately for MD\&A disclosures and footnote disclosures. ${ }^{2}$ Statistics are also presented separately for treatment and non-treatment firms, along with tests for differences in means and medians between the two groups. If my classification of treatment and non-treatment firms is valid, and if my Perl-derived measures capture disclosure changes induced by SFAS 161, treatment firms should exhibit higher values of the footnote-based measures (compared to non-treatment firms). As expected, treatment firms' post-SFAS 161 footnotes contain significantly more quantitative and qualitative derivative information and also present significantly more quantitative derivative information in tabular format. In addition, the average value

\footnotetext{
${ }^{1}$ All variables except for DFACTOR are winsorized at $1 \%$ and $99 \%$.

${ }^{2}$ SeekEdgar provided the service of separating the MD\&A from the footnotes for all sample firms' pre- and post-SFAS 161 10-K filings.
} 
of $D F A C T O R$ is significantly higher for treatment firms when compared to nontreatment firms. The difference for $\triangle G R O U P$ is also positive, but is not statistically significant. ${ }^{3}$

These findings also shed light on the possibility of real effects (i.e., changes in derivative and hedging behavior) confounding my analyses. If real effects are driving the documented changes in derivative and hedging disclosures shown in Table C.2, it would mean that, on average, treatment firms significantly increased their derivative and hedging activities as a result of SFAS 161. However, firms changing their derivative and hedging behavior after the FASB mandated more disclosure would likely be firms whose pre-SFAS 161 derivative and hedging behavior might have been viewed negatively by investors or analysts. In other words, it seems more likely that any real effects of SFAS 161 would lead firms to decrease their derivative and hedging activities, which is inconsistent with the findings in Table C.2. ${ }^{4}$

While SFAS 161 applies only to the financial statement footnotes (the DISCVAR measures in equation (2) are derived from analysis of the footnotes only), the MD\&A also contains related information. Since the 1997 release of the SEC's Financial Re-

${ }^{3}$ Interestingly, the difference for $\triangle W P E R N U M$ is significantly negative. As mentioned previously, I include $\triangle W P E R N U M$ to shed additional light on disclosure characteristics after SFAS 161, but this measure does not capture a disclosure requirement of the new standard. In other words, the significant decrease in $\triangle W P E R N U M$ for treatment firms cannot be used to assess validity of the treatment classification because its value will depend on the relative changes in qualitative versus quantitative disclosure required by SFAS 161.

${ }^{4}$ An issue of The Analyst's Accounting Observer from 2008 describes the potential effects of SFAS 161 on firms using credit derivatives (e.g., credit default swaps). While acknowledging that firms could "enter into more credit derivative transactions that offset existing positions," the article's main theme is that "if the incremental disclosures will cast an unflattering light on the exposures tied to these instruments, then the significant players might do whatever it takes to rid themselves of them before they have to explain them to the world," and "there could be be a lot of panicky dispatching of credit derivatives in the second half of 2008 by players afraid of showing too much exposure" (Ciesielski, 2008, p. 1,4). Consistent with this prediction, the Bank for International Settlements reported that outstanding notional amounts of credit default swap contracts shrank by $27 \%$ in the second half of 2008 and shrank an additional 14\% in the first half of 2009 (BIS, 2009). Also, as mentioned in Section 2.2.2, Zhang (2009) finds that as a result of changes in recognition and disclosure for derivatives and hedging, "SFAS 133 has discouraged firms from engaging in speculative activities" (p. 246). 
porting Release No. 48 (FRR 48), the MD\&A contains information about derivatives and hedging as part of firms' market risk disclosures. As explained by Linsmeier et al. (2002), FRR 48 "requires firms to disclose quantitative market risk information in their 10-K filings for each material category of market risk (e.g., interest rate risk, foreign currency exchange rate risk, commodity price risk)" (p. 345). Firms may disclose this information using tabular display, sensitivity analyses, or value-at-risk disclosures. FRR 48 also "requires 10-K disclosure of market risks inherent in derivatives and in all other, nonderivative financial instruments included within the scope of SFAS No. 107...e.g., investments, loans, structured notes, and debt obligations" (Linsmeier et al., 2002, p. 345).

To further validate my treatment classification, Perl measures, and assumption that my measures are not capturing real effects, I calculate changes in the same disclosure characteristics using the MD\&A from firms' pre- and post-SFAS 161 10-K filings. If the disclosure changes observed in the audited footnote measures (described above) indeed result from SFAS 161 and not from a shift in firms' derivative and hedging behavior, there should be no significant differences in the MD\&A-based measures when comparing treatment and control firms. Stated differently, if a firm changes its derivative and hedging activity because of SFAS 161, disclosure changes should occur in both the footnotes and the MD\&A. Thus, observing changes in footnote disclosures without similar changes in the MD\&A disclosures provides further evidence that my Perl measures are not driven by real effects.

Panel A shows that the MD\&A disclosure characteristics do not have the same pattern as the footnote characteristics discussed previously. ${ }^{5}$ Most of the MD\&A disclosure measures show no significant changes when comparing treatment and nontreatment firms. The notable exceptions are the significant decrease in $\triangle W O R D S$

${ }^{5}$ The only similar finding is the significant difference in the median for $\triangle W P E R N U M$. However, as mentioned previously, this measure cannot be interpreted in the same way as the others because it is not an explicit requirement of SFAS 161. 
$(p<0.01)$ and DFACTOR $(p<0.01)$. While the DFACTOR result is likely driven by the decrease in $\triangle W O R D S$, this decrease in derivative and hedging words and phrases indicates that treatment firms' MD\&As contain significantly less derivative and hedging disclosure after adopting SFAS 161. ${ }^{6}$ A plausible explanation is that firms shift some of their qualitative derivative and hedging discussion to the footnotes when complying with SFAS 161. In untabulated analyses, I investigate whether the overall amount of qualitative derivative and hedging disclosure changed after SFAS 161 by measuring $\triangle W O R D S$ after combining the MD\&A and footnotes. Based on the difference in means, treatment firms have significantly more derivative and hedging words and phrases in the combined disclosure $(p<0.02)$, and the difference in medians indicates an insignificant decrease $(p=0.6305)$. These findings indicate that while some qualitative derivative and hedging discussion may shift from the MD\&A to the footnotes, SFAS 161 still results in an average net increase of derivative and hedging words and phrases in the 10-K. In addition, the other measured characteristics of MD\&A derivative and hedging disclosure (quantitative disclosure, grouping, and tabular display) do not change significantly after SFAS 161.

Overall, the Table C.2 Panel A statistics support my treatment classification and the validity of my footnote disclosure characteristic variables. However, both the treatment and non-treatment samples have very low and very high values of the disclosure change variables, possibly due to some treatment misclassifications, noise in the Perl-derived measures, or both. Table C.2 Panel B presents correlations among the disclosure variables, and Panel C presents Fama/French-12 industry averages for treatment firms' disclosure measures. The industries are sorted in descending order of the footnote DFACTOR to indicate which industries' disclosures were affected most by SFAS 161. I find that the disclosure changes are greatest for firms in the utilities,

${ }^{6}$ Untabulated analyses indicate that there is no significant difference in the MD\&A DFACTOR if $\triangle W O R D S$ is excluded from the factor analysis $(p=0.9546)$. 
energy, consumer non-durables, and manufacturing industries. The industries with the least disclosure changes are consumer durables, business equipment, finance, and healthcare. These findings may indicate industries in which there existed more demand for derivative and hedging disclosure prior to SFAS 161. For example, the finance industry has one of the lowest footnote DFACTOR scores, but financial firms likely engage in significant derivative and hedging activities and may have already been disclosing more derivative and hedging information than firms in other industries.

\subsection{Tests of hypothesis 1}

Table C.3 presents descriptive statistics for the variables used to estimate equations (1) and (2). Panel A contains the variables used for the SPREAD and STDRET models following Bens et al. (2015). The average values of the variables in Panel A are similar to those in Table 1 of Bens et al. (2015), although some differences are expected given that I use quarterly data focused around the issuance of SFAS 161 and Bens et al. (2015) use annual data over a longer sample period (2007 to 2012). Panel B presents statistics for the variables used for the ACCURACY,DISPERSION, UNCTOTAL, and UNCCOMMON models following Lehavy et al. (2011). Average values in my sample are different from those in Lehavy et al.'s Table 2, and my uncertainty proxies also have larger standard deviations, but direct comparisons are difficult because Lehavy et al. (2011) use annual data from 1995 to 2006. The number of observations differs in Panels $\mathrm{A}$ and $\mathrm{B}$ due to missing values of necessary variables in the various specifications. ${ }^{7}$ As expected, approximately half the observations are from the post-SFAS 161 period, and consistent with Table C.1, approximately $73 \%$ (74\% in Panel B) of the observations are from TREAT $=1$ firms. In addition,

7 Panel A's 20,623 observations correspond to 2,606 firms, and Panel B's 16,767 observations correspond to 2,346 firms, indicating some attrition from the 2,631 firms analyzed in Tables C.1 and C.2. 
approximately $0.35 \%$ (0.37\% in Panel B) of words in sample firms' pre-period 10-K filings are related to derivatives and hedging ( $P R E D E R I V$ variable).

Tables C.4 and C.5 present results for testing H1. Each column in these tables represents a different specification of equation (1). Table C.4 presents results with SPREAD and STDRET as the dependent variables (following Bens et al., 2015), and Table C.5 presents results for models with ACCURACY, DISPERSION, UNCTOTAL, and UNCCOMMON as the dependent variables (following Lehavy et al., 2011). All equations are estimated via ordinary least squares with heteroskedasticityrobust standard errors clustered by firm. In these equations, the coefficient of interest is the difference-in-differences estimate, POST $\times T R E A T$, which captures the effect of SFAS 161 on the dependent variable. The predicted signs for the control variables in Table C.4 follow Table 2 Panel B of Bens et al. (2015), and my results are consistent with their findings. In Table C.4, the SPREAD model's coefficient on POST $\times$ TREAT is negative $(-0.069)$ as predicted by $\mathrm{H} 1(t=-4.040, p<0.01)$. Similarly, the STDRET model's coefficient on POST $\times$ TREAT is also negative $(-0.002, t=-3.678, p<0.01)$. These results support H1 and indicate significant reductions in average bid-ask spreads and return volatility during the month following 10-Q and 10-K filings for firms adopting SFAS $161 .^{8}$

Table C.5 presents further tests of H1. The predicted signs on the control variables are based on the findings of Lehavy et al. (2011) (for control variables that are associated in the same direction with all four dependent variables in their Table 7). I also predict (and find) positive coefficient estimates for TREAT because Chang et al. (2015) find that analysts are less accurate and more dispersed when forecasting earnings for new derivative-user firms. In the $A C C U R A C Y$ model of Table C.5, the coefficient on POST $\times$ TREAT is $-0.038(t=-2.415, p<0.01)$.

\footnotetext{
${ }^{8}$ As mentioned in the table notes, $p$-values are based on one-tailed tests for variables with predicted signs, and two-tailed tests otherwise.
} 
Similar results are observed in the UNCTOTAL and UNCCOMMON models. For UNCTOTAL, POST $\times$ TREAT $=-0.040(t=-2.344, p<0.01)$, and for $U N C$ COMMON, POST $\times$ TREAT $=-0.032(t=-1.817, p<0.05)$. The same coefficient in the DISPERSION model is negative but is not significantly different from zero $(t=-0.371) .{ }^{9}$ Like Table C.4, the Table C.5 results support H1 and point to more accuracy and less uncertainty for analysts forecasting earnings of firms adopting SFAS 161.

\subsection{Tests of hypothesis 2}

Tables C.6 and C.7 present results for the various specifications of equation (2). These analyses are identical to those presented in Tables C.4 and C.5 with one exception: the addition of the POST $\times$ TREAT $\times$ DISCVAR interaction term to the models. This triple interaction term captures variation in the extent to which treatment firms' disclosures changed after adopting SFAS 161. H2 predicts a negative coefficient on POST $\times$ TREAT $\times$ DISCVAR, indicating that the findings from Tables C.4 and C.5 should be stronger (i.e., more negative) for firms whose disclosures improved most.

Panel A of Table C.6 presents the various specifications of equation (2) with $S P R E A D$ as the dependent variable. Each column contains results for a different disclosure characteristic (noted in the column headings). ${ }^{10}$ Consistent with H2, the coefficient on POST $\times$ TREAT $\times D I S C V A R$ is negative and significantly different from zero for all specifications, indicating that increased qualitative and quantitative disclosure (captured by $\triangle W O R D S$ and $\triangle N U M S$, respectively), more grouping of similar disclosures $(\triangle G R O U P)$, more tabular display $(\triangle T A B N U M S)$, and more

\footnotetext{
${ }^{9}$ Some prior research (e.g., Holthausen and Verrecchia, 1990; Kondor, 2012; Gallo, 2013) finds that increasing the precision of public information can result in disagreement. This is one possible explanation for the lack of a significant decrease in DISPERSION.

${ }^{10}$ As mentioned previously, the disclosure characteristic variables used in these analyses are based on analysis of the footnotes only.
} 
derivative and hedging words per derivative and hedging number ( $\triangle W P E R N U M)$ are associated with lower average bid-ask spreads following adopting firms' 10-Q and 10-K filings. In addition, the coefficient on POST $\times$ TREAT $\times$ DFACTOR (the last column of Panel A) is the most statistically significant $(t=-7.831, p<0.01)$; this supports that overall disclosure improvements are also associated with lower bid-ask spreads.

Panel B of Table C.6 presents models similar to Panel A except that the dependent variable is STDRET. In contrast to Panel A, H2 is generally not supported in these models. The POST $\times$ TREAT coefficient is still significantly negative in all specifications, but $P O S T \times T R E A T \times D I S C V A R$ is only marginally significant in the $\triangle W P E R N U M$ specification $(t=-1.382, p<0.10) .{ }^{11}$ Given the strong support for H2 in Panel A, the results in Panel B are surprising. They are more puzzling because the sample correlation coefficient between the SPREAD and STDRET uncertainty proxies is 0.5086 (untabulated, $p=0.0000$ ). These findings indicate that improved footnote disclosures may be more associated with reductions in certain types of uncertainty. The stated objective of SFAS 161 to "enhance understanding" does not distinguish between different types of uncertainty, but the results in Table C.6 suggest that the disclosure improvements are more linked to information asymmetry and trading frictions (constructs related to the bid-ask spread).

Table C.7 provides results for estimating the several DISCVAR specifications of equation (2) using the same analyst-based dependent variables as Table C.5. ${ }^{12}$ Panel A presents the $A C C U R A C Y$ models and shows that $P O S T \times T R E A T \times D I S C V A R$ is significantly negative when DISCVAR equals $\triangle W O R D S, \triangle N U M S, \triangle G R O U P$, and

11 Untabulated analyses show that $P O S T \times T R E A T \times D I S C V A R$ is statistically significant in all specifications except for $\triangle G R O U P$ if PRICE and TURNOVER are excluded from the model, perhaps indicating that reduced return volatility is indeed associated with disclosure improvements, but not as strongly as with share price and/or volume.

12 For brevity, the control variables are not displayed. 
DFACTOR. Panel B displays the DISPERSION models, and H2 is weakly supported in the $\triangle$ GROUP specification $(t=-1.557, p<0.10)$, but the POST $\times$ TREAT is never significantly different from zero (consistent with Table C.5). ${ }^{13}$ Panels C and $\mathrm{D}$ show results for the UNCTOTAL and UNCCOMMON models. Interestingly, $P O S T \times T R E A T \times D I S C V A R$ is never statistically different from zero in the UNCCOMMON models, but several disclosure characteristics load negatively in the UNCTOTAL models ( $\triangle W O R D S, \triangle N U M S, \triangle G R O U P$, and DFACTOR). Because UNCCOMMON is defined as the proportion of UNCTOTAL due to shared uncertainty among analysts, the lack of results in Panel D combined with the Panel C results indicates that the disclosure improvements help resolve analysts' individual uncertainty about the firm. It is also notable that $P O S T \times T R E A T \times \triangle T A B N U M S$ is never significant, perhaps implying that with their expertise, analysts do not benefit from increased tabular display. On balance, the results from Tables C.6 and C.7 support H2, although the effect of improvements to particular disclosure characteristics depends on the uncertainty proxy.

13 The $\triangle W P E R N U M$ specification shows that forecast dispersion increases with greater changes in WPERNUM, which contradicts $\mathrm{H} 2$. 


\section{5}

\section{Additional analyses}

\subsection{Association of bid-ask spreads and risk-factor fluctuations}

Because enhanced derivative and hedging disclosure should reduce uncertainty related to firms' risk exposures, I perform an additional analysis to examine the association between the daily bid-ask spread and daily fluctuations in firms' risk factors. This analysis assumes that a portion of the uncertainty captured by the bid-ask spread can be explained by movements in risk factors. For example, if oil is an important input for a firm, I assume that some of the uncertainty associated with the firm is caused by fluctuations in oil prices. If uncertainty stemming from these fluctuations is reduced by SFAS 161 disclosures, I predict that the empirical association between bid-ask spreads and risk-factor movements should decrease for firms adopting the standard. ${ }^{1}$ To test this prediction, I start with the SPREAD models from Table C.4 and Table C.6 Panel A and expand the scope of the analysis to include all days in the year before and the year after the adoption of SFAS $161 .^{2} \mathrm{I}$

\footnotetext{
${ }^{1}$ I focus on bid-ask spreads given the lack of results on the disclosure characteristic variables in the STDRET models from Table C.6.

${ }^{2}$ For example, if a firm adopts SFAS 161 in the first quarter of fiscal year 2009, the pre-period includes all trading days between the Q1 2008 filing date and the Q1 2009 filing date. The post-
} 
include all days to reflect the idea that derivative and hedging disclosures in 10-Q and 10-K filings are useful for understanding the firm-specific implications of risk-factor movements at any time throughout the fiscal period.

In this specification, $S P R E A D$ is the daily bid-ask spread (instead of the average during the month after the 10-Q or 10-K filing as in Tables C.4 and C.6). The PRICE, TURNOVER, and TRADESIZE control variables are also measured daily. All other control variables for a particular firm-day are measured as of the previous fiscal quarter end (except for PREDERIV which is constant for each firm). To measure the daily fluctuations in firms' risk factors, I expand upon the approach used by Linsmeier et al. (2002). They examine 10-K disclosures to identify whether firms are exposed to interest rates, foreign exchange rates, energy prices, and/or non-energy commodity prices. Linsmeier et al. then focus on one risk factor in each category to capture fluctuations for each exposure category. ${ }^{3}$ I do not identify risk exposures from direct examination of 10-K disclosures. Instead, I follow the approach of Guay (1999) and Zhang (2009) and regress firms' monthly returns on the monthly percentage change in underlying risk factors; the absolute value of the coefficient on the monthly percentage change in a risk factor is my estimate of the firm's exposure to that factor.

I focus on the same four risk exposure categories as Linsmeier et al. (2002), but I use more risk factors in order to estimate more specific exposures. Requiring sample firms to have at least 15 monthly returns between December 1, 2004, and December 31, 2007, I run 17 regressions for each firm in order to estimate its exposure to each of 17 different risk factors related to interest rates, foreign exchange rates, energy period includes all trading days between the Q1 2009 filing date and the Q1 2010 filing date.

${ }^{3}$ Their interest rate factor is the 10-year Treasury bond rate, and their foreign exchange rate factor is the U.S. Federal Reserve U.S. dollar-weighted index of foreign exchange rates. Their energy price factor is the Goldman Sachs Commodity Energy Sector Index, and their non-energy commodity price factor is the Goldman Sachs Commodity Non-Energy Sector Index. 
prices, and non-energy commodity prices. $^{4}$ I use the absolute coefficient estimates to divide the firms into separate terciles for each of the 17 risk factors; this means a firm could be in the bottom tercile for one factor and the top or middle tercile for another. ${ }^{5}$ Firms in the bottom tercile for a particular factor are assigned a weight of 0 for that factor, representing little-to-no exposure. Similarly, firms in the middle (top) tercile for a particular factor are assigned a weight of 1 (2) for that factor, capturing medium (high) exposure. I then calculate the daily absolute percentage change for each of the 17 risk factors and calculate a daily weighted average for each firm, using each firm's specific weights. This procedure transforms 17 daily market-wide movements into one summary measure of movement in risk factors that is specific to each firm-day in the sample. ${ }^{6}$

$$
D R I S K_{i t}=\frac{\sum_{r=1}^{r=17} W_{i r} \times|\Delta F A C T O R|_{r t}}{\sum_{r=1}^{r=17} W_{i r}}
$$

In this equation, firms are indexed by $i$, days are indexed by $t$, and the 17 risk factors are indexed by $r$. $W_{i r}$ is firm $i$ 's weight for risk factor $r$ (either 0,1 , or 2 ). $|\triangle F A C T O R|_{r t}$ is the absolute percent change in risk factor $r$ from day $t-1$ to $t$. I then estimate the following regression equations to test for changes in the association between $S P R E A D$ and DRISK after the adoption of SFAS 161:

\footnotetext{
4 The interest rate factors are interest rates on 1-year, 3-year, 5-year, and 10-year interest rate swaps. The foreign exchange factors are U.S. dollar exchange rates for the euro, Japanese yen, pound sterling, Australian dollar, Canadian dollar, Swiss franc, Mexican peso, and Chinese yuan. The energy price factor is the S\&P GSCI Energy Index. The non-energy commodity price factors are the following S\&P GSCI Indices: Agricultural, Industrial Metals, Livestock, and Precious Metals.

${ }^{5}$ Inferences are unchanged if I use quintiles or deciles instead of terciles.

6 The average value of DRISK is 1.2434 for treatment firms and 1.2426 for non-treatment firms. The difference is not significant $(p=0.6083)$. The average value of the sum of the weights (the denominator in equation (3)) is 16.68 for treatment firms and 18.00 for non-treatment firms (the difference is significant with $p=0.0001$ ), indicating that derivative and hedging firms have lower overall risk exposure. This finding is consistent with derivatives being used to reduce risk and not to speculate.
} 


$$
\begin{aligned}
& S P R E A D_{i t}=\alpha_{0}+\sum_{k=-1}^{k=+1} \alpha_{1, k} D R I S K_{i, t+k}+\sum_{k=-1}^{k=+1} \alpha_{2, k} P O S T_{i t} \times D R I S K_{i, t+k} \\
& +\sum_{k=-1}^{k=+1} \alpha_{3, k} T R E A T_{i} \times D R I S K_{i, t+k} \\
& +\sum_{k=-1}^{k=+1} \alpha_{4, k} P O S T_{i t} \times T R E A T_{i} \times D R I S K_{i, t+k} \\
& +\sum_{k=1}^{k=n} \beta_{1, k} C O N T R O L_{k, i t}+\varepsilon_{i t} \\
& S P R E A D_{i t}=\alpha_{0}+\sum_{k=-1}^{k=+1} \alpha_{1, k} D R I S K_{i, t+k}+\sum_{k=-1}^{k=+1} \alpha_{2, k} P O S T_{i t} \times D R I S K_{i, t+k} \\
& +\sum_{k=-1}^{k=+1} \alpha_{3, k} T R E A T_{i} \times D R I S K_{i, t+k} \\
& +\sum_{k=-1}^{k=+1} \alpha_{4, k} P O S T_{i t} \times T R E A T_{i} \times D R I S K_{i, t+k} \\
& +\sum_{k=-1}^{k=+1} \alpha_{5, k} P O S T_{i t} \times T R E A T_{i} \times D I S C V A R_{i} \times D R I S K_{i, t+k} \\
& +\sum_{k=1}^{k=n} \beta_{1, k} C O N T R O L_{k, i t}+\varepsilon_{i t}
\end{aligned}
$$

In equations (4) and (5), $i$ indexes firms, and $t$ captures days. I follow Linsmeier et al. (2002) and include DRISK for days $t-1, t$, and $t+1$ to allow for the possibility that uncertainty on day $t$ reflects past, contemporaneous, or anticipated risk-factor movements. $^{7}$ Also, as in prior specifications, equation (5) is estimated for each of the six disclosure characteristic variables.

\footnotetext{
7 Inferences are similar if risk-factor movements from day $t-1$ are excluded.
} 
Table C.8 presents results of these estimations, and following Linsmeier et al. (2002), coefficients on the DRISK variables are aggregated across days $t-1, t$, and $t+1$. The first column displays results for equation (4). Consistent with predictions, $D R I S K$ is significantly positively associated with $S P R E A D(0.293, t=25.125, p<$ $0.01)$, and $P O S T \times T R E A T \times D R I S K$ is significantly negative $(-0.043, t=-4.142, p<$ 0.01). This indicates that not only is the average post-filing bid-ask spread reduced (Table C.4), but the association of bid-ask spread with risk-factor movements is also reduced. This finding is consistent with SFAS 161 disclosures reducing investor uncertainty stemming from movements in firms' underlying risk factors by providing improved information about how firms use derivatives and hedging to address their exposures. The remaining columns of Table C.8 present the various specifications of equation (5) and show that improvements in all disclosure characteristics result in a greater decrease of this association $(P O S T \times T R E A T \times D I S C V A R \times D R I S K$ is significantly negative in all specifications). These findings provide further support for the view that SFAS 161 improved investor understanding about the purposes and effects of firms' derivative and hedging activities.

\subsection{MD\&A disclosure characteristics}

To provide further support that the results in Tables C.6 through C.8 are due to specific changes in footnote disclosures required by SFAS 161, I repeat all the analyses after including the MD\&A disclosure characteristic measures (described in Table C.2) in the regressions. Table C.9 presents the results; for brevity, only the $P O S T \times T R E A T \times D I S C V A R$ and $P O S T \times T R E A T \times D I S C V A R M D A$ (the interaction term for the MD\&A measures) are presented. In addition, the $p$-value from a test of equality between these two coefficients is also presented for each model. ${ }^{8}$ In the

\footnotetext{
8 The $p$-values are one-tailed under the assumption that the footnote variables have greater effect (i.e., are more negative) than the MD\&A variables.
} 
SPREAD specifications based on Table C.6 and Table C.8, the results show that the footnote disclosure measures matter much more than the MD\&A measures: The $P O S T \times T R E A T \times D I S C V A R$ variable is negative and statistically different from zero in 10 of the 12 specifications while the POST $\times T R E A T \times D I S C V A R M D A$ variable is only significantly negative in the $\triangle W P E R N U M$ specifications. In addition, the estimated coefficients for $P O S T \times T R E A T \times D I S C V A R$ are significantly more negative that the $P O S T \times T R E A T \times D I S C V A R M D A$ coefficients in nine of those 10 specifications.

While most of the tests of differences are not significant for the analyst uncertainty proxies (based on Table C.7), this seems to be due more to imprecision in the estimation of the footnote measure coefficients than to the importance of the MD\&A variables because only one of the MD\&A variables is significantly different from zero at the $p<0.10$ level for the ACCURACY, DISPERSION, and UNCTOTAL specifications. The notable exceptions are the strong results on the MD\&A variables in the UNCCOMMON specifications. Coupled with the lack of results for the footnote measures in Table C.7 Panel D, these results suggest that the common uncertainty in analysts' forecasts is more related to MD\&A disclosure while individual uncertainty depends more on analysts' ability to understand footnote disclosures.

\subsection{Regulatory event study}

To provide additional evidence about the effects of SFAS 161 on investors, I follow Khan et al. (2015) and analyze abnormal returns for treatment and non-treatment firms during the three-day windows centered on the date the FASB's exposure draft was released (December 8, 2006) and the release date of the final standard (March 19, 2008). To calculate abnormal returns, I first estimate the following firm-specific 
daily asset pricing regressions (firms indicated by $i$ and days indexed by $t$ ):

$$
R_{i t}-R_{f t}=\alpha_{i t}+\beta_{1 i}\left(R_{m t}-R_{f t}\right)+\beta_{2 i} S M B_{t}+\beta_{3 i} H M L_{t}+\beta_{4 i} U M D_{t}+\varepsilon_{i t}
$$

In equation (6), $R_{i t}$ is the stock return for firm $i$ on day $t ; R_{f t}$ is the risk-free rate on day $t$; $R_{m t}$ is the market return on day $t ; S M B_{t}, H M L_{t}$, and $U M D_{t}$ are the FamaFrench size, book-to-market, and momentum factors on day $t .{ }^{9}$ For the analysis of December 8, 2006 (March 19, 2008), I estimate this regression for each firm using data from calendar year 2005 (2007) and save the firm-specific coefficient estimates. I then calculate $C A R_{e i}$, the three-day abnormal return for event $e$ and firm $i$ with $t=0$ on the event date:

$$
C A R_{e i}=\sum_{t=-1}^{t=1} R_{i t}-R_{f t}-\left(\hat{\beta}_{1 i}\left(R_{m t}-R_{f t}\right)+\hat{\beta}_{2 i} S M B_{t}+\hat{\beta}_{3 i} H M L_{t}+\hat{\beta}_{4 i} U M D_{t}\right)
$$

To test whether investors perceived SFAS 161 as value-creating for affected firms, I regress $C A R_{e i}$ on TREAT (defined as in all previous models) using heteroskedasticityrobust standard errors. ${ }^{10}$ For the separate (untabulated) models examining December 8, 2006 and March 19, 2008, I find the coefficient on TREAT to be negative and not significantly different from zero (two-tailed $p$-values of 0.366 and 0.262 , respectively). I also estimate an additional model for each event that uses only treatment firms and replaces TREAT with DFACTOR to investigate whether investor perception differs based on the extent to which disclosures are expected to improve after SFAS 161. In other words, while DFACTOR is an ex post measure of actual disclosure changes, this measure is likely positively correlated with ex ante investor perception of the eventual disclosure effects of SFAS 161. In the December 8, 2006 model, the coefficient estimate for DFACTOR is negative and not significantly different from zero ( $p$-value of 0.972). However, in the March 19, 2008 model, the

${ }^{9}$ Firm returns are from CRSP, and the remaining variables are from Ken French's data accessed via WRDS.

${ }^{10}$ Consistent with all previous regression models, $C A R_{e i}$ is winsorized at $1 \%$ and $99 \%$. 
DFACTOR coefficient is significantly positive $(0.00332, t=2.43, p=0.015)$. This indicates that among treatment firms, firms' returns around the release date of SFAS 161 are increasing in the extent to which firms' disclosures would eventually be affected. This result is consistent with my findings that investor uncertainty is reduced after the adoption of SFAS 161.

\subsection{Potential changes in risk exposure}

I also examine changes in firms' total risk exposure after the adoption of SFAS 161. The purposes of this analysis are to (1) validate the method used to calculate DRISK (see Section 5.1), and (2) provide additional evidence that real effects are not driving my main findings. The calculation of DRISK requires firm-specific exposure weights for the 17 risk factors examined (the $W_{i r}$ in equation (3)). As described in Section 5.1, the weights are derived from firm-specific regressions using monthly data from December 2004 through December 2007. By estimating the exposure weights in this way, I assume that the risk exposure weights remain stable during the time period covered by my analyses.

To test this assumption, I re-calculate the weights using two additional time periods: December 2006 through December 2008 (the two calendar years before SFAS 161 adoption) and January 2009 through December 2010 (the two calendar years after SFAS 161). I create a measure of total risk exposure in each period (TOTEXP pre and TOTEXP $\left.P_{\text {post }}\right)$ as the sum of all exposure weights. Because the weights can take the value of 0,1 , or 2 for each of the 17 risk factors, the maximum possible risk exposure is 34 . I then define EXPDIFF $=$ TOTEX $P_{\text {post }}-$ TOTEXP $P_{\text {pre }}$ to examine changes in firms' total risk exposure around the adoption of SFAS 161. The mean (median) value of EXPDIFF is 0.813 (1), indicating that on average, firms' risk exposures are quite stable during my period of analysis. ${ }^{11}$ More importantly, there

11 The 25 th percentile is -5 ; the 75 th percentile is 6 ; and the standard deviation is 8.185 . 
is no significant difference in the mean and median values of EXPDIFF between treatment and non-treatment firms ( $p=0.5823$ and 0.5409 , respectively). ${ }^{12}$ This finding lends additional support to my argument that real effects are not driving the disclosure changes captured by my Perl measures (see Section 4) because if treatment firms were changing their derivative and hedging activities because of SFAS 161, we would expect to observe significantly different values of EXPDIFF (indicating shifts in risk exposure) for treatment firms relative to non-treatment firms.

\subsection{Effects of risk exposure on main results}

In addition to examining potential changes in risk exposure, I re-estimate equations (1) and (2) after including an additional interaction term in the models: POST $\times$ TREAT $\times$ TOTEXP in equation (1) and POST $\times T R E A T \times D I S C V A R \times T O T E X P$ in equation (2). TOTEXP is defined as the sum of a firm's 17 exposure weights $\left(W_{i r}\right.$ in equation (3)) used to calculated DRISK for the analyses in Table C.8. These tests are motivated by research showing that the positive firm-value effects of derivatives and hedging depend on a firm's level of risk exposure (Pérez-González and Yun, 2013). Relying on these findings, I expect the effect of SFAS 161 disclosure changes to be stronger for firms with higher risk exposure because their financial statement users should benefit more from an increased understanding of derivative and hedging activities. Contrary to expectations, I find that POST $\times$ TREAT $\times$ TOTEXP is not significantly negative in any the six specifications of equation (1), and in the SPREAD and DISPERSION models, it is significantly positive (two-tailed $p=0.050$ and 0.033, respectively). Turning to the 36 specifications of equation (2), only five of the $P O S T \times T R E A T \times D I S C V A R \times T O T E X P$ coefficient estimates are significantly negative as expected (one-tailed $p<0.10$ ), and it is significantly positive in four of

12 If the absolute value of EXPDIFF is used, the mean for treatment (non-treatment) firms is 6.613 (6.331), and the median is $6(5)$. The difference in means is not significant $(p=0.2084)$, and the difference in medians is marginally significant $(p=0.0776)$. 
the SPREAD and four of the UNCCOMMON specifications.

Taken together, these results are puzzling given the findings of Pérez-González and Yun (2013). It appears that uncertainty effects documented in the main results are not stronger for firms with higher levels of risk exposure, and it appears that for some measures of uncertainty, the SFAS 161 effects are weaker when overall exposure is higher. One potential explanation is that high-exposure firms are more complex. If this is the case, it may be that SFAS 161 disclosures are still beneficial for these firms' investors and analysts, but not enough to overcome the complexity resulting from high risk exposure. Another possible explanation is that if highexposure firms are more complex, their financial statement users may have demanded more disclosure prior to SFAS 161. This would mean that high-exposure firms' disclosures wouldn't change as much after adopting SFAS 161. Consistent with this argument, TOTEXP is significantly negatively correlated with DFACTOR. The correlation is $-0.0965(p=0.0000)$ in the sample used to estimate the SPREAD and STDRET, and the correlation is $-0.1274(p=0.0000)$ in the sample used for the analyst-based uncertainty proxies.

\subsection{Shifting the period of analysis}

To provide further evidence that the observed results are due to the adoption of SFAS 161, I repeat the analyses (untabulated) from Tables C.4 and C.5 after shifting the period of analysis two years into the past and two years into the future. In other words, I define false adoption dates as the filing date from the same fiscal quarter as the true adoption date, but for two years earlier and then two years later. The results of estimating equation (1) two years earlier show a significantly positive value of POST $\times$ TREAT in the SPREAD, STDRET, ACCURACY, and UNCTOTAL models. The results of estimating equation (1) two years in the future show a mix of negative and positive coefficients on POST $\times$ TREAT, and none are statistically dif- 
ferent from zero (the lowest two-tailed $p$-value is 0.124 in the $A C C U R A C Y$ model). ${ }^{13}$ Given that the analyses in these alternate time periods do not match the findings in Tables C.4 and C.5, I view these results as additional support for concluding that the observed effects are due to SFAS 161.

\subsection{Including only 10-Q filings}

As mentioned previously, SFAS 161 required that interim-period financial reports include derivative and hedging footnote disclosures. To test whether these interim disclosures matter for reducing uncertainty, I repeat the analyses in Tables C.4 through C.7 after excluding all fourth quarters from the sample (untabulated). If only the annual 10-K disclosures matter, the results should no longer hold. I find that the results from these analyses are broadly similar to the main results in regard to significance levels and point estimates. The more notable exceptions include $P O S T \times T R E A T \times \triangle G R O U P$ no longer loading significantly in the SPREAD model; $P O S T \times T R E A T \times \triangle N U M S$ now loading negatively $(p<0.05)$ in the STDRET model; and stronger results on the POST $\times$ TREAT variable (more negative coefficient estimates and $t$-statistics) in the replication of Table C.5. Taken together, these findings provide evidence that the interim-reporting requirement results in reduced uncertainty related to derivatives and hedging.

\footnotetext{
13 I reference two-tailed $p$-values in these tests because these non-SFAS 161 sample periods do not yield clear predictions about the sign of POST $\times$ TREAT.
} 


\section{6}

\section{Conclusion}

I analyze the effects of SFAS 161 derivative and hedging disclosures on investor and analyst uncertainty. Consistent with predictions motivated by the findings of prior research, I provide evidence that uncertainty decreased for firms adopting SFAS 161. In addition, I show that for some uncertainty proxies (particularly the bid-ask spread), firms whose disclosures were more affected by SFAS 161 exhibit a greater decrease in uncertainty. I also find a decreased association between the bid-ask spread and movements in risk factors, consistent with less uncertainty stemming from these movements. I interpret these results as an indication that SFAS 161 improved derivative and hedging disclosures, leading to enhanced investor understanding.

My findings may be of interest to standard setters as they proceed with their hedge accounting and Disclosure Framework projects and consider how to improve the effectiveness of financial statement footnotes. The FASB's hedge accounting project was only recently activated, and the Board may find evidence on the effects of SFAS 161 useful as they reconsider derivative and hedging disclosures. In addition, as part of the Disclosure Framework project, the FASB is reviewing disclosure requirements for items such as pensions, income taxes, and fair values. Like deriva- 
tive and hedging activities, these arrangements can be complicated and difficult to understand. My findings that disclosure improvements are linked to decreases in certain measures of uncertainty may be useful as the Board considers disclosures in these other settings as well.

My paper contributes to the literature by studying the effects of changes to derivative and hedging disclosures for a large sample of firms across many industries. In addition, I develop methods using Perl scripts and a custom dictionary of 188 words and phrases to shed light on five characteristics of derivative and hedging disclosures that correspond to disclosure characteristics being considered by the FASB: the amount of qualitative information, disaggregation of quantitative information, grouping of similar information, tabular display of quantitative information, and the ratio of qualitative to quantitative information. Future research could employ these methods to study the relations among these (and other) disclosure characteristics. In addition, future research might consider the implications of the extent to which certain characteristics are more or less prevalent in disclosures related to other topics in firms' financial reports. These methods might also be useful for examining whether disclosure characteristics are associated with other firm attributes such as executive compensation, litigation risk, or corporate governance. 


\section{Appendix A}

\section{Summary of SFAS 133 and SFAS 161 disclosure requirements}


Table A.1

Summary of SFAS 133 and SFAS 161 disclosure requirements

\begin{tabular}{|c|c|c|}
\hline Disclosure Type & SFAS 133 Requirements & SFAS 161 Requirements \\
\hline $\begin{array}{l}\text { Objectives of Derivative } \\
\text { and Hedging Activities }\end{array}$ & $\begin{array}{l}\text { - Classification by hedge type then by risk management } \\
\text { policy. } \\
\text { - Description of purposes of non-hedging derivative } \\
\text { activity. } \\
\text { - Additional qualitative risk management disclosures } \\
\text { are encouraged. }\end{array}$ & $\begin{array}{l}\text { - Informs preparers that the disclosures' objective is users' } \\
\text { understanding of derivative and hedging activities. } \\
\text { - Classification by underlying risk exposure, then risk management } \\
\text { purposes, then by hedge type. } \\
\text { - Additional qualitative risk management disclosures are encouraged. } \\
\text { - Description of purposes of non-hedging derivative activity. } \\
\text { - Information about the volume of derivative activity. }\end{array}$ \\
\hline $\begin{array}{l}\text { Balance Sheet } \\
\text { Information }\end{array}$ & $\begin{array}{l}\text { - Fair values separated by assets vs. liabilities (SFAS } \\
\text { 107). } \\
\text { - Clear link to what is reported on the balance sheet } \\
\text { (SFAS 107). }\end{array}$ & $\begin{array}{l}\text { - Fair value of derivatives separated by: } \\
\circ \quad \text { assets vs. liabilities, } \\
\circ \text { hedging vs. non-hedging, and } \\
\circ \text { risk exposure category. } \\
\text { - Balance sheet line items that contain the fair values of the various } \\
\text { categories. }\end{array}$ \\
\hline $\begin{array}{l}\text { Income Statement } \\
\text { Information }\end{array}$ & $\begin{array}{l}\text { - Fair value hedges: } \\
\circ \text { Net gain or loss from: hedge ineffectiveness; } \\
\text { exclusion from effectiveness testing; and hedge } \\
\text { disqualification. } \\
\text { - Cash flow hedges: } \\
\circ \quad \text { Net gain or loss from: hedge ineffectiveness and } \\
\text { exclusion from effectiveness testing. } \\
\circ \quad \text { Gross gains and losses from hedge } \\
\text { disqualification. } \\
\circ \quad \text { Description of events that reclassify gains and } \\
\text { losses from AOCI to earnings and an estimate } \\
\text { of the amount to be reclassified within } 12 \\
\text { months. } \\
\circ \quad \text { Maximum length of time over which non- } \\
\text { variable-interest cash flow variability is hedged. } \\
\text { - Net investment hedges: } \\
\circ \quad \text { Net gain or loss from effective hedging } \\
\text { recognized in OCI. } \\
\text { - Description of where these gains and losses are } \\
\text { reported on the income statement. } \\
\text { - Similar disclosures for related financial instruments } \\
\text { are encouraged. }\end{array}$ & $\begin{array}{l}\text { - Fair value hedges: } \\
\circ \text { Net gain or loss from: hedge ineffectiveness; exclusion from } \\
\text { effectiveness testing; and hedge disqualification. } \\
\circ \quad \text { Gross gains and losses by risk exposure category from: } \\
\text { hedging instruments and related hedged items. } \\
\text { - Cash flow hedges: } \\
\circ \text { Gross gains and losses by risk exposure category from: } \\
\text { effective hedging recognized in OCI; effective hedging } \\
\text { reclassified from AOCI; hedge ineffectiveness; exclusion from } \\
\text { effectiveness testing; and hedge disqualification. } \\
\circ \quad \text { Description of events that reclassify gains and losses from } \\
\text { AOCI to earnings and an estimate of the amount to be } \\
\text { reclassified within } 12 \text { months. } \\
\circ \text { Maximum length of time over which non-variable-interest } \\
\text { cash flow variability is hedged. } \\
\text { - Net investment hedges: } \\
\circ \text { Gross gains and losses by risk exposure category from: } \\
\text { effective hedging recognized in OCI; effective hedging } \\
\text { reclassified from AOCI; hedge ineffectiveness; and exclusion } \\
\text { from effectiveness testing. } \\
\text { - Non-hedging derivatives: } \\
\circ \text { Gross gains and losses by risk exposure category. } \\
\circ \quad \text { Or, firms can combine gains and losses from non-hedging } \\
\text { derivatives with gains and losses from other trading } \\
\text { instruments by risk exposure category. } \\
\text { - Income statement line items that contain these various gains and } \\
\text { losses. } \\
\text { Similar disclosures for related financial instruments are encouraged. }\end{array}$ \\
\hline $\begin{array}{l}\text { Credit-risk-related } \\
\text { Contingent Features }\end{array}$ & - Not required & $\begin{array}{l}\text { - Existence and nature of these features and how the features might } \\
\text { be triggered in derivatives that are net liabilities. } \\
\text { - Aggregate fair values of derivatives with such features that are net } \\
\text { liabilities. } \\
\text { - Aggregate fair value of assets that are posted as collateral, would } \\
\text { be posted as collateral, or would be required to settle the } \\
\text { instrument if such features were triggered. }\end{array}$ \\
\hline Frequency & - Annual & - Annual and interim \\
\hline Cross-referencing & - Not required & - Required if information is presented in more than one footnote. \\
\hline Presentation Format & - No guidelines & $\begin{array}{l}\text { - Tabular format for balance sheet and income statement } \\
\text { information. }\end{array}$ \\
\hline
\end{tabular}


17. DERIVATIVE FINANCIAL INSTRUMENTS

The Company is exposed to market risks from adverse changes in:

- commodity prices affecting the cost of raw materials and energy,

- $\quad$ foreign exchange rates, and

interest rates.

In the normal course of business, these risks are managed through a variety of strategies, including the use of derivatives.

Commodity futures and options contracts are used to reduce the volatility of commodity input prices on items such as natural gas, vegetable oils, proteins, dairy, grains, and electricity. Generally, the Company economically hedges a portion of its anticipated consumption of conmodity inputs for periods ranging from 12 to 36 months. The Company may enter into longer-term economic hedges on particular commodities if deemed appropriate. As of May 25, 2008, the Company had economically hedged certain portions of its anticipated consumption of commodity inputs through November 2010 .

In order to reduce exposures related to changes in foreign currency exchange rates, the Company, when deemed prudent, enters into forward exchange or option contracts to economically hedge transactions denominated in a currency other than the applicable functional currency. This
sales of finished goods, and future settlement of foreign-denominated assets and liabilities.

From time to time, the Company may use derivative instruments, including interest rate swaps, to reduce exposures related to changes in interest rates. At the end of fiscal 2008, 2007, and 2006, the Company had no interest rate swap agreements outstanding

In prior periods, the Company has designated certain derivatives as fair value hedges or cash flow hedges qualifying for hedge accounting treatment. The Company discontinued designating derivatives as cash flow hedges during the first quarter of fiscal 2008 and had no qualifying fair value hedges during the periods covered by this report.

Gains and losses associated with designated cash flow hedges were deferred in accumulated other comprehensive income until the underlying hedged item impacted earnings. At that time, the Company reclassified net gains and losses from cash flow hedges into the same line item of the consolidated statement of earnings as where the effects of the hedged item are recorded, typically cost of goods sold. As of May 27, 2007 the deferred gain, net of tax, recognized in accumulated other comprehensive income was $\$ 4.9$ million.

Hedge ineffectiveness for cash flow hedges may impact net earnings when a change in the value of a hedge does not offset the change in the value of the underlying hedged item. For fiscal 2008 2007, and 2006, the ineffectiveness associated with derivatives designated as cash flow hedges from continuing operations was a loss of \$1.1 million, a loss of \$3.3 million, and a gain of \$3.1 million

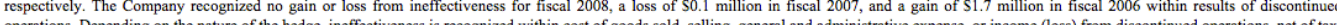
operations. Depending on the nature of the hedge, ineffectiveness is recognized within cost of goods sold, selling, general and administrative expense, or income (loss) from discontinued operations, net of tax The Company does not exclude any component of the hedging instrument's gain or loss when assessing ineffectivenes.

Many of the Company's derivatives do not qualify for, and, as noted above, the Company is not currently designating any derivatives to achieve hedge accounting treatment. Changes in the market value of deri
transaction.

In addition to using derivatives to manage risk, the Company engages in the trading of commodities and related derivatives in the normal course of business. This trading occurs primarily in the option contracts, as well as forward cash purchase contracts and forward cash sales contracts of energy and agricultural commodities are used as components of trading and merchandising strategies.

All derivative instruments are recognized on the balance sheet at fair value. The fair value of derivative assets is recognized within prepaid expenses and other current assets, and current assets held for sale, while the fair value of derivative liabilities is recognized within other accrued liabilities and current liabilities held for sale. As of May 25, 2008 and May 27, 2007, the total fair value of derivativ assets recognized within prepaid expenses and other current assets was $\$ 207.0$ million and $\$ 60.5$ million, respectively, while the anount recognized within current assets held for sale was $\$ 536.6$ million and \$299.5 million, respectively. As of May 25, 2008 and May 27, 2007, the fair value of derivatives recognized within other accrued liabilities was \$55.8 million and S15.3 million, respectively while the amoun

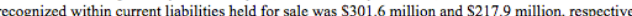

Figure A.1: Pre-SFAS 161 derivative footnote for ConAgra Foods, Inc. 


\section{DERIVATIVE FINANCIAL INSTRUMENTS}

Our operations are exposed to market risks from adverse changes in commodity prices affecting the cost of raw materials and energy, foreign currency exchange rates, and interest rates. In the normal course of business, these risks are managed through a variety of strategies, including the use of derivatives.

Commodity futures and options contracts are used from time to time to economically hedge commodity input prices on items such as natural gas, vegetable oils, proteins, dairy, grains, and electricity. Generally, we economically hedge a portion of our anticipated consumption of commodity inputs for periods of up to 36 months. We may enter into longer-term economic hedges on particular commodities if deemed appropriate. As of May 31, 2009, we had economically hedged certain portions of our anticipated consumption of commodity inputs using derivative instruments with expiration dates through July 2010.

In order to reduce risk related to changes in foreign currency exchange rates, when deemed prudent, we enter into forward exchange or option contracts for transactions denominated in a currency other than the applicable functional currency. This includes, but is not limited to, hedging against foreign currency risk in purchasing inventory and capital equipment, sales of finished goods, and future settlement of foreign-denominated assets and liabilities. As of May 31, 2009, we had economically hedged certain portions of our foreign currency risk of anticipated transactions using derivative instruments with expiration dates through November 2009.

Derivatives Designated as Cash Flow Hedges

From time to time, we may use derivative instruments, including interest rate swaps, to reduce risk related to changes in interest rates. During the fourth quarter of fiscal 2009, we entered into an interest rate swap to hedge the interest rate risk related to our then-anticipated long term debt refinancing. We designated this interest rate swap as a cash flow hedge of the forecasted interest payments related to this debt refinancing. The loss associated with this swap, which is deferred in accumulated other comprehensive loss at May 31, 2009 is $\$ 0.7$ million. This loss is being amortized over the life of the related debt. No other interest rate swap agreements were outstanding during the periods presented.

In prior periods, we designated certain commodity-based and foreign currency derivatives as cash flow hedges qualifying for hedge accounting treatment. We discontinued designating such derivatives as cash flow hedges during the first quarter of fiscal 2008.

Gains and losses associated with designated commodity cash flow hedges were deferred in accumulated other comprehensive income until the underlying hedged item impacted earnings. At that time, we reclassified net gains and losses from cash flow hedges into the same line item of the consolidated statement of earnings as where the effects of the hedged item were recorded, typically cost of goods sold.

Hedge ineffectiveness for cash flow hedges may impact net earnings when a change in the value of a hedge does not offset the change in the value of the underlying hedged item. The ineffectiveness associated with derivatives designated as cash flow hedges from continuing operations was a loss of \$1.1 million and a loss of \$3.3 million for fiscal 2008 and 2007, respectively. Depending on the nature of the hedge, ineffectiveness is recognized within cost of goods sold or selling, general and administrative expense. We do not exclude any component of the hedging instrument's gain or loss when assessing ineffectiveness.

Economic Hedges of Forecasted Cash Flows

Many of our derivatives do not qualify for, and, as noted above, we are not currently designating any commodity or foreign currency derivatives to achieve hedge accounting treatment. Beginning in the first quarter of

fiscal 2009, we began to reflect realized and unrealized gains and losses from derivatives used to hedge anticipated commodity consumption and to mitigate foreign currency cash flow risk in earnings immediately within general corporate expense (within cost of goods sold). The gains and losses are reclassified to segment operating results in the period in which the underlying item being hedged is recognized in cost of goods sold. Prior to the first quarter of fiscal 2009, these derivative gains and losses were recorded immediately in our segment results as a component of cost of goods sold or selling, general and administrative expenses, regardless of when the item being hedged impacted earnings.

Other Derivative Activity (Primarily in the Milling Operations)

We also use derivative instruments within our milling operations, which are part of the Commercial Foods segment. Derivative instruments used to economically hedge commodity inventories and forward purchase and sales contracts are marked-to-market such that realized and unrealized gains and losses are immediately included in operating results. The underlying inventory and forward contracts being hedged are also marked-to-market with changes in market value recognized immediately in operating results.

For commodity derivative trading activities within our milling operations that are not intended to mitigate commodity input cost risk, the derivative instrument is marked-to-market each period with gains and losses included in net sales of the Commercial Foods segment. In fiscal 2009, there were no material gains or losses from derivative trading activities. In fiscal 2008, net derivative gains from trading activities of \$23.3 million, were included in the results of operations for the Commercial Foods segment.

All derivative instruments are recognized on the balance sheet at fair value. The fair value of derivative assets is recognized within prepaid expenses and other current assets and current assets held for sale, while the fair value of derivative liabilities is recognized within other accrued liabilities and current liabilities held for sale. In accordance assets and current assets held for sale, while the fair value of derivative liabilities is recognized within other accrued liabilities and current liabilities held for sale. In accordance
with FASB Interpretation Number (FIN) 39, Offsetting of Amounts Related to Certain Contracts, as amended, we offset certain derivative asset and liability balances, as well as with FASB Interpretation Number (FIN) 39 , Offsetting of Amounts Related to Certain Contracts, as amended, we offset certain derivative
certain amounts representing rights to reclaim cash collateral and obligations to return cash collateral, where legal right of setoff exists.

Derivative assets and liabilities and amounts representing a right to reclaim cash collateral are reflected in our balance sheets as follows:

\begin{tabular}{|c|c|c|c|c|}
\hline \multirow[b]{2}{*}{ Prepaid expenses and other current assets } & \multicolumn{2}{|c|}{$\underset{2009}{\operatorname{May} 31,}$} & \multicolumn{2}{|c|}{$\underset{2008}{\operatorname{May} 25}$} \\
\hline & $\$$ & 52.1 & $\$$ & 207.0 \\
\hline Current assets held for sale & & - & & 536.6 \\
\hline Other accrued liabilities & & 30.8 & & 55.8 \\
\hline Current liabilities held for sale & & - & & 301.6 \\
\hline
\end{tabular}

The following table presents our derivative assets and liabilities not designated as hedging instruments under SFAS No. 133, on a gross basis, prior to the offsetting of amounts where legal right of setoff exists at May 31, 2009:

\section{Commodity contracts \\ Foreign exchange contracts \\ Other \\ Total derivatives not designated as hedging \\ instruments under SFAS No. 133}

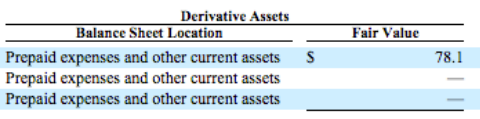

Prepaid expenses and other current assets

Prepaid expenses and other current assets
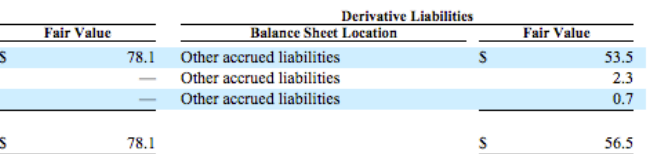

Other accrued liabililitities

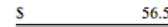

$\mathrm{S} \quad 56.5$

were as follows:

For the Fifly-three Weeks Ended May 31, 2009

Derivatives Not Designated as Hedging,
Instruments Under FASB Statement 133

Commodity contracts

Foreign exchange contracts

Other

Statement of

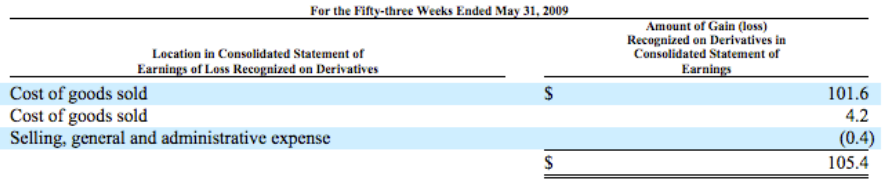

Figure A.2: Post-SFAS 161 derivative footnote for ConAgra Foods, Inc. 


\section{Appendix B}

\section{Variable definitions and dictionary}

Table B.1: Variable definitions

\begin{tabular}{l|l}
\hline SPREAD & $\begin{array}{l}\text { The natural log of the average daily bid-ask spread during the calendar month } \\
\text { following the 10-Q or 10-K filing date. For each firm-day, the bid-ask spread is } \\
\text { measured from the CRSP Daily Stock File as 'ASK' - 'BID' scaled by the average of } \\
\text { 'ASK' and 'BID'. In Table 8, SPREAD is the log of the daily bid-ask spread instead } \\
\text { of the average. }\end{array}$ \\
\hline The standard deviation of daily returns (CRSP Daily Stock File 'RET') during the \\
calendar month following the 10-Q or 10-K filing date.
\end{tabular}




\begin{tabular}{|c|c|}
\hline Variable & Definition \\
\hline$A C C U R A C Y$ & $\begin{array}{l}\text { The square of the difference between the IBES 'ACTUAL' and IBES 'MEANEST', } \\
\text { scaled by the CRSP share price } 90 \text { days prior to the consensus calculation date. The } \\
\text { IBES variables are taken from the IBES Summary U.S. EPS file and correspond to the } \\
\text { first consensus forecast calculation ('STATPERS') following the } 10-\mathrm{Q} \text { or } 10-\mathrm{K} \text { filing } \\
\text { date. In other words, ACCURACY captures the accuracy of the first consensus } \\
\text { forecast for quarter } t+1 \text { after the filing of the } 10-\mathrm{Q} \text { or } 10-\mathrm{K} \text { for quarter } t \text {. }\end{array}$ \\
\hline DISPERSION & $\begin{array}{l}\text { The standard deviation of analyst forecasts (IBES 'STDEV'), scaled by the CRSP } \\
\text { share price } 90 \text { days prior to the consensus calculation date. The IBES variables are } \\
\text { taken from the IBES Summary U.S. EPS file and correspond to the first consensus } \\
\text { forecast calculation ('STATPERS') following the } 10-\mathrm{Q} \text { or } 10-\mathrm{K} \text { filing date. In other } \\
\text { words, DISPERSION captures the forecast dispersion corresponding to the first } \\
\text { consensus forecast for quarter } t+1 \text { after the filing of the } 10-\mathrm{Q} \text { or } 10-\mathrm{K} \text { for quarter } t \text {. } \\
D I S P E R S I O N \text { is set to zero if only one analyst contributes to the consensus. }\end{array}$ \\
\hline UNCTOTAL & $\begin{array}{l}\text { Total analyst uncertainty following Lehavy et al.'s (2011) implementation of Barron et } \\
\text { al.'s (1998) equation (15). See page } 1098 \text { in Lehavy et al. (2011). }\end{array}$ \\
\hline$U N C C O M M O N$ & $\begin{array}{l}\text { Common analyst uncertainty following Lehavy et al.'s (2011) implementation of } \\
\text { Barron et al.'s (1998) equation (16). See page } 1098 \text { in Lehavy et al. (2011). }\end{array}$ \\
\hline$L O G M C A P$ & $\begin{array}{l}\text { The natural log of the market cap at the end of the fiscal quarter measured from the } \\
\text { Compustat Quarterly database as the product of 'PRCCQ' and 'CSHOQ'. }\end{array}$ \\
\hline GROWTH & $\begin{array}{l}\text { The compound average sales growth over quarters } t-5 \text { to } t-3 \text { measured from the } \\
\text { Compustat Quarterly database as }\left(\frac{S A L E Q_{t-3}}{S A L E Q_{t-5}}\right)^{2}-1\end{array}$ \\
\hline LOGSEGMENTS & $\begin{array}{l}\text { The natural log of the number of business segments reported in the Compustat } \\
\text { Segments database for the prior fiscal year. Set to zero if the firm does not appear in } \\
\text { the Segments database. }\end{array}$ \\
\hline PINST & $\begin{array}{l}\text { The percentage of institutional ownership measured as of the most recent 'RDATE' in } \\
\text { the Thomson Reuters s } 34 \text { database occurring before the end of the fiscal quarter. }\end{array}$ \\
\hline$M F C O U N T$ & $\begin{array}{l}\text { The count of management forecasts issued during the three months ending with the } \\
10-\mathrm{Q} \text { or } 10-\mathrm{K} \text { filing date, measured from the IBES Guidance Detail file. }\end{array}$ \\
\hline$N E W S$ & $\begin{array}{l}\text { The sum of the market-adjusted return (measured from CRSP as 'RTN' - } \\
\text { 'VWRETD') over the days }(0,1) \text { relative to the } 10-\mathrm{K} \text { or } 10 \text {-Q filing date. }\end{array}$ \\
\hline$S G A$ & $\begin{array}{l}\text { SG\&A expenses scaled by operating income, measured from the previous fiscal quarter } \\
\text { from the Compustat Quarterly database as 'XSGAQ' scaled by 'XOPRQ'. If either } \\
\text { variable is missing or if 'XOPRQ' is zero, } S G A \text { is set to zero. }\end{array}$ \\
\hline$D R I S K$ & $\begin{array}{l}\text { The weighted average of daily absolute percentage changes in a firm's underlying risk } \\
\text { factors. The } 17 \text { risk factors used are interest rates on 1-year, 3-year, 5-year, and } \\
10 \text {-year interest rate swaps ('swaps_y1', 'swaps_y3', 'swaps_y5', and 'swaps_y10' } \\
\text { variables from the daily Federal Reserve Interest Rates dataset on WRDS); U.S. dollar } \\
\text { exchange rates for the euro, Japanese yen, pound sterling, Australian dollar, Canadian } \\
\text { dollar, Swiss franc, Mexican peso, and Chinese yuan ('exuseu', 'exjpus', 'exusuk', } \\
\text { 'exusal', 'excaus', 'exszus', 'exmxus', and 'exchus' variables from the daily Federal } \\
\text { Reserve Foreign Exchange Rates dataset on WRDS); and the following S\&P GSCI } \\
\text { Indices: Energy, Agricultural, Industrial Metals, Livestock, and Precious Metals } \\
\text { (SPGSEN, SPGSAG, SPGSIN, SPGSLV, and SPGSPM Bloomberg tickers). Using } \\
\text { different swap maturities allows for differences in the length of firms' interest rate } \\
\text { exposures. I use the eight most common currencies for U.S. dollar-paired foreign } \\
\text { exchange deals (see Table } 3 \text { in the Bank for International Settlements' } 2013 \text { foreign } \\
\text { exchange report: www.bis.org/publ/rpfx13fx.pdf). Requiring sample firms to have at } \\
\text { least } 15 \text { monthly returns between December } 1 \text {, } 2004 \text {, and December } 31 \text {, } 2007 \text {, I run } 17 \\
\text { regressions for each firm in order to estimate its exposure to each of the } 17 \text { risk factors. } \\
\text { I then use the absolute coefficient estimates to divide the firms into separate terciles for } \\
\text { each of the } 17 \text { risk factors; this means a firm could be in the bottom tercile for one } \\
\text { factor and the top or middle tercile for another. Firms in the bottom tercile for a } \\
\text { particular factor are assigned a weight of } 0 \text { for that factor, representing little-to-no } \\
\text { exposure. Similarly, firms in the middle (top) tercile for a particular factor are assigned } \\
\text { a weight of } 1 \text { (2) for that factor, capturing medium (high) exposure. I then calculate } \\
\text { the daily absolute percentage change for each of the } 17 \text { risk factors and calculate the } \\
\text { weighted average for each firm, using each firm's specific weights. This procedure } \\
\text { transforms } 17 \text { daily market-wide movements into one summary measure of movement } \\
\text { in risk factors that is specific to each firm-day in the sample: } \\
\qquad D R I S K_{i t}=\frac{\sum_{r=1}^{r=17} W_{i r} \times|\Delta F A C T O R|}{r t}+\sum_{r=1}^{r=17} W_{i r}\end{array}$ \\
\hline
\end{tabular}

In this equation, firms are indexed by $i$, days are indexed by $t$, and the 17 risk factors are indexed by $r$. $W_{i r}$ is firm $i$ 's weight for risk factor $r$ (either 0,1 , or 2).

$|\triangle F A C T O R|_{r t}$ is the absolute percent change in risk factor $r$ from day $t-1$ to $t$. 


\begin{tabular}{l|l}
\hline Variable & Definition \\
\hline POST & An indicator variable set equal to one (zero) for all observations on or after (before)
\end{tabular}
the filing date of the firm's initial SFAS 161 filing. Note that the adoption date used to determine the value of POST can be different for each firm. In other words, there is not one date applied to all firms in determining POST. The adoption date is determined by filings meeting one of the following two criteria: (1) a first, second or third fiscal quarter ending between February 15, 2009 and May 15, 2009; or (2) a first fiscal quarter ending between May 16, 2009 and August 15, 2009.

TREAT $\quad$ An indicator variable set equal to one if the firm mentions SFAS 161 in any of its 10-K or 10-Q filings (or variants of those filings) filed between March 1, 2008 and December 31,2009 and also has at least 10 derivative and hedging words or phrases in its pre-SFAS 161 10-K filing. To identify SFAS 161 terminology, I used the EDGAR full-text search to search for "161" in 51 10-Ks and 50 10-Qs filed between October 16 , 2009 and October 31, 2010 (the earliest searchable date for the full-text search is October 16, 2009). I noted the various ways in which firms referred to SFAS 161. Examples include "SFAS No. 161" and "Statement of Financial Accounting Standards No. 161." I then converted these various phrases into regular expressions and used a Perl script to strip all filings of HTML and search for these phrases. The regular expressions are: "\(?.?S?FAS.? \)? (No \.)? ?161", "Standards (No \.)? ?161", "Statement (No \.)? ?161", "FAS-161", "\(?.?ASC.?\)? ?815", "ASC Topic 815", and "ASC section 815".

\begin{tabular}{l|l} 
Filing Analysis & For all pre-period 10-K and post-period 10-K filings (the 10-Ks filed immediately
\end{tabular}

Details before and after a firm adopts SFAS 161), I download the full text file from the EDGAR website. I then sent these files to SeekEdgar to have them split into separate files for the MD\&A and footnotes. See Table C.1 Panel A for more details on requirements for retained filings.

\begin{tabular}{l|l}
$W O R D S$ & The percentage of all words in the filing segment (either footnotes or MD\&A)
\end{tabular} matching my derivative and hedging dictionary. Total words are identified by counting all alphabetic strings of at least two characters that are surrounded by non-alphabetic characters (Perl regular expression: $\left.\left(?<=\left[{ }^{\wedge} \mathrm{A}-\mathrm{Z}\right]\right)([\mathrm{A}-\mathrm{Z}][\mathrm{A}-\mathrm{Z}]+)\left(?=\left[{ }^{\wedge} \mathrm{A}-\mathrm{Z}\right]\right)\right)$. To construct the derivative and hedging dictionary, I copied the derivative footnote text for 94 derivative-user firms and counted the frequency of all unique words, two-word phrases, and three-word phrases appearing in this corpus of 94 derivative footnotes. I manually inspected each word appearing at least 100 times in the entire corpus (230 words corresponding to $76.27 \%$ of all words in the corpus). For unambiguous words like "derivative" and "hedge", the words were added to the dictionary. However, for ambiguous words like "interest" and "contracts", the lists of unique phrases appearing at least five times in the corpus were manually inspected for any phrase that contained the word of interest. If the phrase pertained to derivative and hedging activities, the phrase was added to the dictionary, but not the original word. For example, "forward interest rate" is in the dictionary, but "interest" is not. The final derivative and hedging dictionary is comprised of 188 words and phrases. Finally, before counting words and word percentages, the spaces are removed in all dictionary phrases in all filings (i.e., "gas collars" is replaced with "gascollars") so that each instance of each phrase contributes once to both numerator and denominator when calculating the dictionary percentage for each filing. The 188 words and phrases are listed in a table following the variable definitions.

$\triangle W O R D S \quad$ WORDS from the post-period 10-K footnotes minus WORDS from the pre-period
$10-\mathrm{K}$ footnotes.

NUMS $\quad$ For each filing, I perform two separate procedures. First, I strip the filing of all HTML
tags and then use Perl's Lingua::EN::Sentence module to parse the text into sentences. For all sentences with at least three words, the sentence is checked to see if it contains a match from the derivative and hedging dictionary. If it contains a dictionary word or phrase, the count of all numbers in the sentence is retained after removing numbers related to dates, accounting standards, footnotes, and Level 1/2/3 financial instruments (numbers are identified with the Perl regular expression $[\backslash s \backslash-\backslash \$ \backslash(] \backslash \mathrm{d}+)$. Second, I reanalyze the filing and retain the HTML tags in order to identify tables containing derivative and hedging information. For each HTML table, I check each cell for purely numeric content (the Perl regular expression is

$\left.\backslash \mathrm{A}\left[\backslash \$ \backslash(\backslash-\backslash \mathrm{s}]^{*}[0123456789, \backslash .]+[\backslash) \backslash \mathrm{s}\right]^{*} \backslash \mathrm{z}\right)$. If the cell is identified as containing only numeric content, I check all cells in the same column directly above the numeric cell and all cells in the same row directly behind (to the left of) the numeric cell. If any of these cells contain words or phrases matching the derivative dictionary, the numeric cell is counted as a derivative/hedging number. NUMS is the sum of the counts from these two procedures, multiplied by 100 and scaled by the total number of words in the $10-\mathrm{K}$ footnotes. In other words, it is the total count of numbers related to derivative and hedging, whether they appear in sentences or in tables.

\begin{tabular}{l|l}
$\triangle N U M S$ & NUMS from the post-period 10-K footnotes minus $N U M S$ from the pre-period 10-K
\end{tabular}




\begin{tabular}{|c|c|}
\hline Variable & Definition \\
\hline GROUP & $\begin{array}{l}\text { For each filing, the location of each dictionary word or phrase is retained and added to } \\
\text { a list (i.e., if the first, second, and fifth words in the document matched the derivative } \\
\text { and hedging dictionary, the list would be populated with } 1,2 \text {, and } 5 \text { ). Each number in } \\
\text { the list is then multiplied by } 100 \text { and scaled by the total word count in the document. } \\
\text { I then take the standard deviation of this scaled list of dictionary match locations. } \\
\text { Larger standard deviations correspond to more dispersed derivative and hedging } \\
\text { information. GROUP then equals this standard deviation multiplied by }-1 \text { so that its } \\
\text { sign in the regressions is consistent with the other disclosure variables. }\end{array}$ \\
\hline$\triangle G R O U P$ & $\begin{array}{l}\text { GROUP from the post-period } 10-\mathrm{K} \text { footnotes minus } G R O U P \text { from the pre-period } \\
10-\mathrm{K} \text { footnotes. }\end{array}$ \\
\hline$T A B N U M S$ & $\begin{array}{l}\text { The percentage of } N U M S \text { related to tabular presentation. In other words, it is the } \\
\text { count from the second procedure described for the } N U M S \text { variable, which is then } \\
\text { multiplied by } 100 \text { and divided by the total count of derivative and hedging numbers. }\end{array}$ \\
\hline$\triangle T A B N U M S$ & $\begin{array}{l}T A B N U M S \text { from the post-period } 10-\mathrm{K} \text { footnotes minus } T A B N U M S \text { from the } \\
\text { pre-period } 10 \text {-K footnotes. }\end{array}$ \\
\hline$W P E R N U M$ & $\begin{array}{l}\text { The number of derivative and hedging words and phrases divided by the number of } \\
\text { derivative and hedging numbers. }\end{array}$ \\
\hline$\triangle W P E R N U M$ & $\begin{array}{l}W P E R N U M \text { from the post-period } 10-\mathrm{K} \text { footnotes minus } W P E R N U M \text { from the } \\
\text { pre-period } 10-\mathrm{K} \text { footnotes. }\end{array}$ \\
\hline DFACTOR & $\begin{array}{l}\text { The first factor with an eigenvalue greater than one emerging from a principal } \\
\text { component factor analysis of } \triangle W O R D S, \triangle N U M S, \triangle G R O U P \text {, and } \triangle T A B N U M S \text {. } \\
\text { See footnote } 5 \text { in Chapter } 3 \text { for more details. }\end{array}$ \\
\hline
\end{tabular}


Table B.2

Derivative and hedging dictionary

\begin{tabular}{|c|c|c|c|c|c|c|c|c|}
\hline Word or phrase & Frequency & $\%$ & Word or phrase & Frequency & $\%$ & Word or phrase & Frequency & $\%$ \\
\hline $\begin{array}{l}\text { derivative } \\
\text { d }\end{array}$ & 89,633 & $16.29 \%$ & option contracts & 1,980 & $0.36 \%$ & risk exposure & 622 & $0.11 \%$ \\
\hline derivatives & 40,128 & $7.29 \%$ & currency risk & 1,954 & $0.36 \%$ & forward contract & 573 & $0.10 \%$ \\
\hline hedge & 39,949 & $7.26 \%$ & highly effective & 1,606 & $0.29 \%$ & exposed to interest & 552 & $0.10 \%$ \\
\hline underlying & 35,718 & $6.49 \%$ & call options & 1,517 & $0.28 \%$ & exposure related to & 530 & $0.10 \%$ \\
\hline hedging & 32,752 & $5.95 \%$ & exchange forward & 1,512 & $0.27 \%$ & collateral requirements & 519 & $0.09 \%$ \\
\hline swap & 31,887 & $5.80 \%$ & exchange risk & 1,478 & $0.27 \%$ & designated and qualify & 487 & $0.09 \%$ \\
\hline swaps & 25,903 & $4.71 \%$ & currency contracts & 1,437 & $0.26 \%$ & to floating & 476 & $0.09 \%$ \\
\hline hedges & 23,980 & $4.36 \%$ & rate movements & 1,313 & $0.24 \%$ & forward starting & 468 & $0.09 \%$ \\
\hline credit risk & 18,587 & $3.38 \%$ & fluctuations in interest & 1,300 & $0.24 \%$ & rate volatility & 460 & $0.08 \%$ \\
\hline hedged & 17,431 & $3.17 \%$ & rate lock & 1,300 & $0.24 \%$ & market fluctuations & 452 & $0.08 \%$ \\
\hline exposure to & 17,322 & $3.15 \%$ & strike price & 1,233 & $0.22 \%$ & mitigate the risk & 450 & $0.08 \%$ \\
\hline rate risk & 15,782 & $2.87 \%$ & exposed to market & 1,228 & $0.22 \%$ & forward purchase & 442 & $0.08 \%$ \\
\hline market risk & 14,422 & $2.62 \%$ & credit risks & 1,194 & $0.22 \%$ & exposed to foreign & 429 & $0.08 \%$ \\
\hline notional & 12,963 & $2.36 \%$ & rate contracts & 1,135 & $0.21 \%$ & pay fixed & 396 & $0.07 \%$ \\
\hline counterparty & 9,724 & $1.77 \%$ & rate exposure & 1,134 & $0.21 \%$ & to fixed rate & 389 & $0.07 \%$ \\
\hline risk management & 6,936 & $1.26 \%$ & put options & 1,088 & $0.20 \%$ & forward sale & 386 & $0.07 \%$ \\
\hline futures & 6,225 & $1.13 \%$ & commodity contracts & 1,068 & $0.19 \%$ & cap agreements & 385 & $0.07 \%$ \\
\hline functional currency & 5,476 & $1.00 \%$ & manage interest & 1,014 & $0.18 \%$ & speculative or trading & 385 & $0.07 \%$ \\
\hline exchange contracts & 5,172 & $0.94 \%$ & rate caps & 986 & $0.18 \%$ & contracts designated & 376 & $0.07 \%$ \\
\hline price volatility & 4,180 & $0.76 \%$ & rate cap & 966 & $0.18 \%$ & forward currency & 375 & $0.07 \%$ \\
\hline forward contracts & 4,151 & $0.75 \%$ & trading or speculative & 889 & $0.16 \%$ & credit protection & 372 & $0.07 \%$ \\
\hline price risk & 3,928 & $0.71 \%$ & contracts outstanding & 883 & $0.16 \%$ & post collateral & 369 & $0.07 \%$ \\
\hline currency forward & 3,669 & $0.67 \%$ & master netting & 881 & $0.16 \%$ & contango & 366 & $0.07 \%$ \\
\hline ineffectiveness & 3,355 & $0.61 \%$ & currency exposure & 855 & $0.16 \%$ & rate instruments & 357 & $0.06 \%$ \\
\hline rate fluctuations & 3,191 & $0.58 \%$ & additional collateral & 843 & $0.15 \%$ & default risk & 355 & $0.06 \%$ \\
\hline concentrations of credit & 3,120 & $0.57 \%$ & effective in offsetting & 836 & $0.15 \%$ & instruments designated & 353 & $0.06 \%$ \\
\hline effective portion & 2,594 & $0.47 \%$ & price fluctuations & 827 & $0.15 \%$ & offsetting changes & 351 & $0.06 \%$ \\
\hline designated as cash & 2,487 & $0.45 \%$ & certain risks & 785 & $0.14 \%$ & offset by changes & 348 & $0.06 \%$ \\
\hline cash collateral & 2,399 & $0.44 \%$ & currency exposures & 755 & $0.14 \%$ & currency forwards & 322 & $0.06 \%$ \\
\hline market risks & 2,172 & $0.39 \%$ & netted against & 707 & $0.13 \%$ & degree of risk & 317 & $0.06 \%$ \\
\hline credit exposure & 2,031 & $0.37 \%$ & risk profile & 667 & $0.12 \%$ & exposed to credit & 313 & $0.06 \%$ \\
\hline ineffective portion & 2,023 & $0.37 \%$ & forward sales & 656 & $0.12 \%$ & receive fixed & 307 & $0.06 \%$ \\
\hline
\end{tabular}




\begin{tabular}{|c|c|c|c|c|c|c|c|c|}
\hline Word or phrase & Frequency & $\%$ & Word or phrase & Frequency & $\%$ & Word or phrase & Frequency & $\%$ \\
\hline manage risk & 300 & $0.05 \%$ & to fixed interest & 158 & $0.03 \%$ & designated as net & 59 & $0.01 \%$ \\
\hline financial contracts & 296 & $0.05 \%$ & forward rate & 153 & $0.03 \%$ & forward purchases & 56 & $0.01 \%$ \\
\hline commodity risk & 294 & $0.05 \%$ & contracts are designated & 152 & $0.03 \%$ & credit contracts & 54 & $0.01 \%$ \\
\hline contracts to mitigate & 291 & $0.05 \%$ & price exposure & 149 & $0.03 \%$ & contracts subject to & 53 & $0.01 \%$ \\
\hline designated and qualifies & 290 & $0.05 \%$ & netting agreements & 148 & $0.03 \%$ & volatility of cash & 47 & $0.01 \%$ \\
\hline forward exchange & 287 & $0.05 \%$ & traded contracts & 144 & $0.03 \%$ & gas options & 35 & $0.01 \%$ \\
\hline ineffective portions & 285 & $0.05 \%$ & collateral posting & 132 & $0.02 \%$ & options and forward & 35 & $0.01 \%$ \\
\hline contracts to reduce & 282 & $0.05 \%$ & commodity forward & 131 & $0.02 \%$ & netting agreement & 33 & $0.01 \%$ \\
\hline forward rates & 273 & $0.05 \%$ & manage exposures & 127 & $0.02 \%$ & reduce our exposure & 32 & $0.01 \%$ \\
\hline margin deposits & 271 & $0.05 \%$ & contracts not designated & 121 & $0.02 \%$ & floor contract & 30 & $0.01 \%$ \\
\hline collateral pledged & 270 & $0.05 \%$ & primary risks & 117 & $0.02 \%$ & manage its exposure & 27 & $0.00 \%$ \\
\hline rate options & 270 & $0.05 \%$ & short position & 111 & $0.02 \%$ & put contracts & 22 & $0.00 \%$ \\
\hline options contracts & 258 & $0.05 \%$ & posted collateral & 108 & $0.02 \%$ & mitigate exposure & 20 & $0.00 \%$ \\
\hline manage this risk & 257 & $0.05 \%$ & economic exposure & 104 & $0.02 \%$ & manage exposure & 18 & $0.00 \%$ \\
\hline currency options & 255 & $0.05 \%$ & forward and option & 98 & $0.02 \%$ & collateral paid & 17 & $0.00 \%$ \\
\hline exchange risks & 254 & $0.05 \%$ & contracts to offset & 96 & $0.02 \%$ & margin cash & 17 & $0.00 \%$ \\
\hline effectiveness testing & 253 & $0.05 \%$ & gas collars & 89 & $0.02 \%$ & equity collars & 16 & $0.00 \%$ \\
\hline forward interest rate & 241 & $0.04 \%$ & netting arrangements & 89 & $0.02 \%$ & netting arrangement & 12 & $0.00 \%$ \\
\hline strike rate & 237 & $0.04 \%$ & spot exchange & 88 & $0.02 \%$ & aluminum contracts & 11 & $0.00 \%$ \\
\hline effective portions & 234 & $0.04 \%$ & contracts to protect & 86 & $0.02 \%$ & excluded from effectiveness & 11 & $0.00 \%$ \\
\hline exchange contract & 229 & $0.04 \%$ & exchange forwards & 80 & $0.01 \%$ & gas purchase options & 11 & $0.00 \%$ \\
\hline instruments not designated & 213 & $0.04 \%$ & master agreements & 80 & $0.01 \%$ & post margin & 11 & $0.00 \%$ \\
\hline instruments to mitigate & 211 & $0.04 \%$ & forwards and options & 79 & $0.01 \%$ & spread contracts & 11 & $0.00 \%$ \\
\hline power contract & 207 & $0.04 \%$ & equity contracts & 78 & $0.01 \%$ & effective at inception & 7 & $0.00 \%$ \\
\hline energy contracts & 199 & $0.04 \%$ & commodity cash flow & 75 & $0.01 \%$ & undesignated positions & 7 & $0.00 \%$ \\
\hline mitigate this risk & 198 & $0.04 \%$ & reduce the exposure & 74 & $0.01 \%$ & spread positions & 6 & $0.00 \%$ \\
\hline designated and qualifying & 193 & $0.04 \%$ & long position & 67 & $0.01 \%$ & contracts not subject & 2 & $0.00 \%$ \\
\hline ceiling price & 182 & $0.03 \%$ & risk related contingent & 67 & $0.01 \%$ & forward asset & 2 & $0.00 \%$ \\
\hline receive variable & 182 & $0.03 \%$ & manage the foreign & 66 & $0.01 \%$ & TOTAL & 550,232 & $100.00 \%$ \\
\hline collar contracts & 179 & $0.03 \%$ & margin call & 64 & $0.01 \%$ & \multirow{3}{*}{\multicolumn{3}{|c|}{$\begin{array}{l}\text { This table presents the frequency of each dictionary word } \\
\text { and phrase in the } 5,26210 \text {-K filings analyzed (two filings for } \\
\text { each of the } 2,631 \text { sample firms). }\end{array}$}} \\
\hline fluctuations in commodity & 165 & $0.03 \%$ & oil collars & 64 & $0.01 \%$ & & & \\
\hline assessment of effectiveness & 158 & $0.03 \%$ & written options & 62 & $0.01 \%$ & & & \\
\hline
\end{tabular}


Appendix C

Figures and tables 
Figure C.1

Research Design

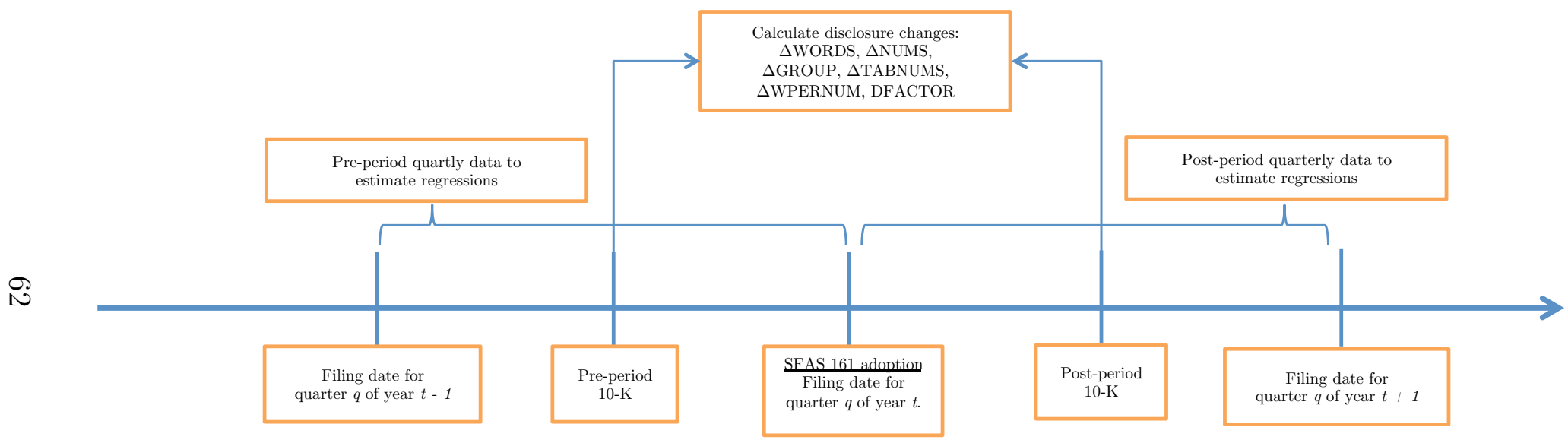

Figure C.1: Research design. This figure summarizes the research design for estimating equations (1) and (2). SFAS 161 adoption periods are either (1) a first, second, or third fiscal quarter ending between February 15, 2009 and May 15, 2009; or (2) a first fiscal quarter ending between May 16, 2009 and August 15, 2009. The pre- and postperiods are defined to be approximately one year in length. Observations are retained for all 10-Q and 10-K filings between the filing date for quarter $q$ of year $t-1$ and the filing date for quarter $q$ of year $t+1$. Sample firms are required to have either 7 or 8 quarterly observations in this time period. 
Table C.1

Sample Description

Panel A: Sample selection procedures

1. Firms with WRDS SEC Analytics Suite filings 10-K, 10-KNT, 10-Q, 10-QT, 10KSB, or 10QSB with

9,610

the following characteristics: (1) filed between January 1, 2007 and December 31, 2010; (2) non-

missing GVKEY, fiscal period end date (RDATE), and filing date (FDATE); (3) FDATE after

RDATE; and (4) no duplicates on GVKEY-RDATE

2. Firms without Compustat data or with duplicate Compustat data

3. Firms headquartered outside the United States

4. Firms with filing date errors (absolute difference between FDATE year and Compustat fiscal year greater than one)

5. Firms with filings not associated with initial adoption of SFAS 161. SFAS 161 adoption observations

Teet one of two conditions: (1) A first, second, or third fiscal quarter ending between 2/15/2009 and 5/15/2009; or (2) A first fiscal quarter ending between 5/16/2009 and 8/15/2009. Firms also must have a pre-period start date, post-period start date, pre-period 10-K filing, and post-period 10-K

6. Firms without CRSP PERMNO

7. Firms without valid filings for Perl textual analysis programs due to (1) failed extraction of MD\&A and/or financial statement footnotes; (2) file size less than $100 \mathrm{~KB}$; or (3) no HTML in the filing

Total number of firms available for footnote disclosure analyses

Panel B: Sample distribution by Fama-French 12 industry and SFAS 161 treatment

\begin{tabular}{rlrr}
\multicolumn{4}{c}{ Firms not affected by SFAS 161 (TREAT $=0)$} \\
\hline FF12 & Industry & $\mathrm{N}$ & $\%$ \\
\hline 1 & Consumer non-durables & 21 & 2.91 \\
2 & Consumer durables & 9 & 1.25 \\
3 & Manufacturing & 30 & 4.16 \\
4 & Energy & 20 & 2.77 \\
5 & Chemicals and allied products & 8 & 1.11 \\
6 & Business equipment & 148 & 20.53 \\
7 & Telecommunications & 18 & 2.50 \\
8 & Utilities & 10 & 1.39 \\
9 & Shops & 85 & 11.79 \\
10 & Healthcare & 115 & 15.95 \\
11 & Finance & 156 & 21.64 \\
12 & Other & 101 & 14.01 \\
\hline & Total & 721 & 100.00
\end{tabular}

\begin{tabular}{rlrr}
\multicolumn{5}{c}{ Firms affected by SFAS 161 (TREAT $=1)$} \\
\hline FF12 & Industry & $\mathrm{N}$ & $\%$ \\
\hline 1 & Consumer non-durables & 78 & 4.08 \\
2 & Consumer durables & 40 & 2.09 \\
3 & Manufacturing & 170 & 8.90 \\
4 & Energy & 115 & 6.02 \\
5 & Chemicals and allied products & 49 & 2.57 \\
6 & Business equipment & 319 & 16.70 \\
7 & Telecommunications & 45 & 2.36 \\
8 & Utilities & 67 & 3.51 \\
9 & Shops & 151 & 7.91 \\
10 & Healthcare & 163 & 8.53 \\
11 & Finance & 509 & 26.65 \\
12 & Other & 204 & 10.68 \\
\hline & Total & 1910 & 100.00
\end{tabular}


Table C.2

SFAS 161 Textual Dislcosure Measures

Panel A: Descriptve statistics

\begin{tabular}{|c|c|c|c|c|c|c|c|c|c|}
\hline \multirow{2}{*}{ Non-treated firms } & & $\mathrm{N}$ & Mean & Std. Dev. & $5 \%$ & $25 \%$ & Median & $75 \%$ & $95 \%$ \\
\hline & $\Delta$ WORDS & 721 & $\begin{array}{l}-0.003 \\
\end{array}$ & 0.059 & -0.083 & -0.020 & -0.002 & 0.013 & 0.087 \\
\hline \multirow{5}{*}{$\stackrel{3}{3}$} & $\triangle \mathrm{NUMS}$ & 721 & 0.001 & 0.036 & -0.043 & -0.005 & 0.000 & 0.005 & 0.051 \\
\hline & $\triangle$ GROUP & 721 & -0.331 & 7.365 & -14.478 & -2.293 & 0.000 & 1.709 & 11.880 \\
\hline & $\triangle$ TABNUMS & 721 & 0.840 & 8.916 & 0.000 & 0.000 & 0.000 & 0.000 & 0.000 \\
\hline & $\triangle$ WPERNUM & 721 & -0.472 & 4.836 & -8.000 & -0.611 & 0.000 & 0.132 & 5.667 \\
\hline & DFACTOR & 721 & 0.084 & 0.598 & -0.590 & -0.067 & 0.064 & 0.189 & 0.943 \\
\hline \multirow{6}{*}{ 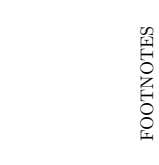 } & $\triangle$ WORDS & 721 & 0.005 & 0.088 & -0.093 & -0.017 & -0.001 & 0.012 & \\
\hline & $\triangle$ NUMS & 721 & 0.005 & 0.050 & $\begin{array}{l}-0.050 \\
-0.050\end{array}$ & -0.008 & $\begin{array}{r}-0.001 \\
0.000\end{array}$ & 0.006 & $\begin{array}{l}0.124 \\
0.074\end{array}$ \\
\hline & $\triangle$ GROUP & 721 & 0.190 & 6.782 & -12.257 & -2.126 & 0.000 & 2.308 & 12.206 \\
\hline & $\triangle$ TABNUMS & 721 & 2.072 & 16.356 & -13.333 & 0.000 & 0.000 & 0.000 & 31.818 \\
\hline & $\triangle$ WPERNUM & 721 & -0.228 & 3.533 & -5.667 & -0.500 & 0.000 & 0.389 & 5.273 \\
\hline & DFACTOR & 721 & -0.356 & 0.597 & -0.957 & -0.530 & -0.435 & -0.344 & 0.917 \\
\hline \multirow[t]{2}{*}{ Treated firms } & & $\mathrm{N}$ & Mean & Std. Dev. & $5 \%$ & $25 \%$ & Median & $75 \%$ & $95 \%$ \\
\hline & $\triangle \mathrm{WORDS}$ & 1910 & $\begin{array}{l}-0.029 \\
\end{array}$ & 0.118 & -0.226 & -0.081 & -0.022 & 0.022 & 0.158 \\
\hline \multirow{5}{*}{$\stackrel{\Delta}{\Delta}$} & $\triangle$ NUMS & 1910 & 0.002 & 0.073 & -0.116 & -0.023 & 0.000 & 0.024 & 0.127 \\
\hline & $\triangle$ GROUP & 1910 & -0.325 & 6.518 & -11.260 & -2.680 & -0.226 & 2.037 & 10.556 \\
\hline & $\triangle$ TABNUMS & 1910 & 0.723 & 13.881 & -16.667 & 0.000 & 0.000 & 0.000 & 20.400 \\
\hline & $\triangle$ WPERNUM & 1910 & -0.622 & 5.106 & -10.000 & -1.233 & -0.074 & 0.450 & 6.889 \\
\hline & DFACTOR & 1910 & -0.032 & 1.113 & -1.842 & -0.450 & -0.023 & 0.340 & 1.825 \\
\hline \multirow{6}{*}{ 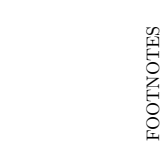 } & $\triangle$ WORDS & 1910 & 0.049 & 0.172 & -0.169 & -0.062 & 0.007 & 0.131 & 0.392 \\
\hline & $\triangle$ NUMS & 1910 & 0.051 & 0.104 & -0.068 & -0.009 & 0.019 & 0.094 & 0.272 \\
\hline & $\triangle$ GROUP & 1910 & 0.310 & 5.759 & -9.654 & -2.123 & 0.381 & 2.936 & 9.298 \\
\hline & $\triangle$ TABNUMS & 1910 & 10.522 & 21.605 & -16.081 & 0.000 & 2.389 & 21.212 & 50.355 \\
\hline & $\triangle$ WPERNUM & 1910 & -0.873 & 3.715 & -7.845 & -1.500 & -0.333 & 0.230 & 3.633 \\
\hline & DFACTOR & 1910 & 0.134 & 1.085 & -1.218 & -0.603 & -0.201 & 0.774 & 2.266 \\
\hline
\end{tabular}

Tests for differences between treated and non-treated firms

\begin{tabular}{|c|c|c|c|c|c|}
\hline & & \multicolumn{2}{|c|}{$t$-test for difference in means } & \multicolumn{2}{|c|}{$\begin{array}{l}\text { Wilcoxon rank-sum test for } \\
\text { difference in medians }\end{array}$} \\
\hline \multirow{7}{*}{ 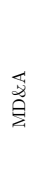 } & & Difference & $\underline{t \text {-stat }}$ & Difference & $\underline{Z \text {-stat }}$ \\
\hline & $\Delta$ WORDS & -0.03 & $-5.76 * * *$ & -0.02 & $-7.64 * * *$ \\
\hline & $\triangle N U M S$ & 0.00 & 0.12 & 0.00 & 0.08 \\
\hline & $\triangle$ GROUP & 0.01 & 0.02 & -0.23 & -0.84 \\
\hline & $\triangle$ TABNUMS & -0.12 & -0.21 & 0.00 & 0.29 \\
\hline & $\triangle$ WPERNUM & -0.15 & -0.68 & -0.07 & $-2.66 * * *$ \\
\hline & DFACTOR & -0.12 & $-2.66 * * *$ & -0.09 & $-5.22 * * *$ \\
\hline \multirow{6}{*}{ 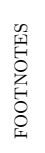 } & $\triangle$ WORDS & 0.04 & $6.51 * * *$ & 0.01 & $3.16 * * *$ \\
\hline & $\triangle \mathrm{NUMS}$ & 0.05 & $11.45 * * *$ & 0.02 & $11.42 * * *$ \\
\hline & $\triangle$ GROUP & 0.12 & 0.45 & 0.38 & 1.50 \\
\hline & $\triangle \mathrm{TABNUMS}$ & 8.45 & $9.52 * * *$ & 2.39 & $11.89 * * *$ \\
\hline & $\triangle$ WPERNUM & -0.65 & $-4.03 * * *$ & -0.33 & $-7.45 * * *$ \\
\hline & DFACTOR & 0.49 & $11.51 * * *$ & 0.23 & $9.11 * * *$ \\
\hline
\end{tabular}




\begin{tabular}{|c|c|c|c|c|c|c|c|c|c|c|c|c|}
\hline & $\begin{array}{r}\text { MD\&A } \\
\text { DWORDS }\end{array}$ & MD\&A & MD\&A & MD\&A & MD\&A & MD\&A & FNOTE & FNOTE & FNOTE & FNOTE & FNOTE & FNOTE \\
\hline & $\Delta$ WORDS & $\triangle \mathrm{NUMS}$ & $\triangle$ GROUP & $\triangle$ TABNUMS & $\triangle$ WPERNUM & DFACTOR & $\triangle$ WORDS & $\Delta$ NUMS & $\triangle$ GROUP & $\triangle$ TABNUMS & $\triangle$ WPERNUM & DFACTOR \\
\hline MD\&A $\triangle W O R D S$ & & $0.438^{*}$ & $\begin{array}{c}-0.006 \\
\end{array}$ & $0.063^{*}$ & $0.104^{*}$ & $0.784^{*}$ & $0.276^{*}$ & $0.141^{*}$ & 0.016 & 0.003 & 0.025 & $0.186^{*}$ \\
\hline MD\&A $\triangle$ NUMS & $0.523^{*}$ & & $-0.062^{*}$ & $0.134^{*}$ & $-0.366^{*}$ & $0.773^{*}$ & $0.197^{*}$ & $0.246^{*}$ & 0.036 & 0.025 & $-0.086^{*}$ & $0.199^{*}$ \\
\hline MD\&A $\triangle$ GROUP & $-0.042^{*}$ & $-0.039^{*}$ & & 0.007 & 0.003 & -0.025 & 0.025 & 0.021 & 0.029 & -0.009 & 0.036 & 0.016 \\
\hline MD\&A $\triangle$ TABNUMS & $0.151^{*}$ & $0.314^{*}$ & -0.000 & & $-0.078^{*}$ & $0.248^{*}$ & $0.039 *$ & $0.054^{*}$ & -0.013 & $0.069^{*}$ & -0.019 & $0.067^{*}$ \\
\hline MD\&A $\triangle W P E R N U M$ & $0.047^{*}$ & $-0.165^{*}$ & -0.013 & $-0.087^{*}$ & & $-0.124^{*}$ & 0.014 & $-0.072^{*}$ & -0.010 & 0.003 & $0.144^{*}$ & -0.017 \\
\hline MD\&A DFACTOR & $0.781^{*}$ & $0.861^{*}$ & -0.032 & $0.577^{*}$ & $-0.093^{*}$ & & $0.273^{*}$ & $0.224^{*}$ & 0.021 & 0.028 & -0.027 & $0.231^{*}$ \\
\hline FNOTE $\Delta$ WORDS & $0.242^{*}$ & $0.163^{*}$ & 0.007 & $0.062^{*}$ & 0.004 & $0.217^{*}$ & & $0.638^{*}$ & $0.152^{*}$ & $0.323^{*}$ & 0.016 & $0.824^{*}$ \\
\hline FNOTE $\triangle$ NUMS & $0.103^{*}$ & $0.196^{*}$ & 0.011 & 0.027 & -0.036 & $0.157^{*}$ & $0.647^{*}$ & & $0.108^{*}$ & $0.404^{*}$ & $-0.368^{*}$ & $0.832^{*}$ \\
\hline FNOTE $\triangle$ GROUP & -0.000 & 0.003 & 0.027 & -0.018 & 0.019 & -0.005 & $0.076^{*}$ & $0.084^{*}$ & & $0.042^{*}$ & -0.031 & $0.081^{*}$ \\
\hline FNOTE $\triangle$ TABNUMS & 0.015 & 0.014 & 0.011 & $0.106^{*}$ & 0.029 & $0.051^{*}$ & $0.330^{*}$ & $0.342^{*}$ & -0.002 & & $-0.128^{*}$ & $0.619^{*}$ \\
\hline FNOTE $\triangle$ WPERNUM & 0.006 & $-0.045^{*}$ & $0.047^{*}$ & 0.008 & $0.140^{*}$ & -0.017 & $0.052^{*}$ & $-0.146^{*}$ & -0.005 & $-0.047^{*}$ & & $-0.165^{*}$ \\
\hline FNOTE DFACTOR & $0.160^{*}$ & $0.166^{*}$ & 0.011 & $0.078^{*}$ & -0.004 & $0.186^{*}$ & $0.854^{*}$ & $0.858^{*}$ & $0.049^{*}$ & $0.657^{*}$ & $-0.059^{*}$ & \\
\hline \multicolumn{13}{|l|}{ Panel C: Treated firms' industry av } \\
\hline & MD\&A & MD\&A & MD\&A & MD\&A & MD\&A & MD\&A & FNOTE & FNOTE & FNOTE & FNOTE & FNOTE & FNOTE \\
\hline & $\triangle$ WORDS & $\Delta$ NUMS & $\triangle$ GROUP & $\triangle$ TABNUMS & $\triangle$ WPERNUM & DFACTOR & $\triangle$ WORDS & $\triangle$ NUMS & $\triangle$ GROUP & $\triangle$ TABNUMS & $\triangle$ WPERNUM & DFACTOR \\
\hline 8 - Utilities & -0.030 & -0.005 & 0.479 & -1.851 & 0.173 & -0.156 & 0.134 & 0.131 & 1.806 & 12.283 & -0.613 & 0.783 \\
\hline 4 - Energy & -0.049 & 0.013 & -0.165 & 1.143 & -0.587 & -0.014 & 0.094 & 0.106 & 1.279 & 13.140 & -0.953 & 0.569 \\
\hline 1 - Consumer non-durables & -0.014 & 0.005 & 0.636 & 0.603 & -1.193 & 0.060 & 0.117 & 0.077 & 1.532 & 13.532 & -1.046 & 0.501 \\
\hline 3 - Manufacturing & -0.039 & -0.002 & -0.248 & -1.437 & -0.551 & -0.166 & 0.098 & 0.070 & 1.409 & 14.059 & -0.707 & 0.422 \\
\hline 5 - Chemicals and allied products & -0.040 & -0.007 & -1.620 & -0.600 & -0.389 & -0.185 & 0.094 & 0.062 & 0.697 & 10.350 & 0.222 & 0.310 \\
\hline 9 - Shops & -0.019 & -0.001 & 0.101 & 1.041 & -0.637 & 0.004 & 0.065 & 0.049 & 0.373 & 10.973 & -1.020 & 0.177 \\
\hline 12 - Other & -0.028 & 0.004 & 0.465 & 1.758 & -0.967 & 0.018 & 0.052 & 0.058 & 0.690 & 9.936 & -0.653 & 0.163 \\
\hline 7 - Telecommunications & -0.016 & -0.003 & -0.661 & -0.861 & -0.119 & -0.055 & 0.044 & 0.033 & 0.237 & 14.112 & -0.152 & 0.093 \\
\hline 2 - Consumer durables & -0.050 & -0.002 & -1.147 & 3.333 & -0.836 & -0.085 & 0.031 & 0.043 & 1.148 & 12.247 & -1.101 & 0.068 \\
\hline 6 - Business equipment & -0.025 & 0.008 & -0.349 & 1.274 & -0.578 & 0.052 & 0.035 & 0.039 & -0.380 & 10.266 & -1.390 & 0.035 \\
\hline 11 - Finance & -0.029 & -0.001 & -0.758 & 1.149 & -0.550 & -0.041 & 0.013 & 0.033 & -0.226 & 7.897 & -0.731 & -0.097 \\
\hline 10 - Healthcare & -0.026 & -0.001 & -0.607 & -0.010 & -0.793 & -0.062 & 0.012 & 0.025 & -0.526 & 10.472 & -1.061 & -0.098 \\
\hline
\end{tabular}


Table C.3

Descriptive Statistics for Regression Variables

Panel A: Regression variables for SPREAD and STDRET models

\begin{tabular}{lrrrrrrrr}
\hline & $\mathrm{N}$ & Mean & Std. Dev. & $5 \%$ & $25 \%$ & Median & $75 \%$ & $95 \%$ \\
\hline SPREAD & 20623 & -5.637 & 1.475 & -7.537 & -6.741 & -6.031 & -4.686 & -2.718 \\
STDRET & 20623 & 0.042 & 0.030 & 0.012 & 0.022 & 0.033 & 0.053 & 0.104 \\
POST & 20623 & 0.498 & 0.500 & 0.000 & 0.000 & 0.000 & 1.000 & 1.000 \\
TREAT & 20623 & 0.726 & 0.446 & 0.000 & 0.000 & 1.000 & 1.000 & 1.000 \\
ROA & 20623 & -0.010 & 0.066 & -0.132 & -0.007 & 0.004 & 0.015 & 0.042 \\
LEV & 20623 & 0.577 & 0.280 & 0.136 & 0.362 & 0.573 & 0.792 & 0.955 \\
BTM & 20623 & 0.917 & 1.013 & 0.066 & 0.367 & 0.661 & 1.107 & 2.744 \\
SIZE & 20623 & 6.725 & 1.870 & 3.589 & 5.418 & 6.724 & 7.959 & 9.939 \\
PRICE & 20623 & 18.024 & 18.130 & 1.097 & 5.053 & 12.435 & 25.169 & 53.445 \\
TURNOVER & 20623 & -5.190 & 1.214 & -7.604 & -5.866 & -4.964 & -4.355 & -3.518 \\
FOLLOW & 20623 & 1.432 & 1.048 & 0.000 & 0.000 & 1.609 & 2.303 & 2.996 \\
PASTSTDRET & 20623 & 0.045 & 0.030 & 0.014 & 0.024 & 0.037 & 0.057 & 0.105 \\
TRADESIZE & 20623 & 247.506 & 184.074 & 133.513 & 152.717 & 179.710 & 251.844 & 632.461 \\
PREDERIV & 20623 & 0.347 & 0.269 & 0.057 & 0.135 & 0.268 & 0.493 & 0.886
\end{tabular}

Panel B: Regression variables for ACCURACY, DISPERSION, UNCTOTAL, and UNCCOMMON models

\begin{tabular}{lrrrrrrrr}
\hline & $\mathrm{N}$ & Mean & Std. Dev. & $5 \%$ & $25 \%$ & Median & $75 \%$ & $95 \%$ \\
\hline ACCURACY & 16767 & 0.103 & 0.689 & 0.000 & 0.000 & 0.000 & 0.002 & 0.103 \\
DISPERSION & 16767 & 0.009 & 0.035 & 0.000 & 0.000 & 0.001 & 0.004 & 0.030 \\
UNCTOTAL & 16767 & 0.118 & 0.762 & 0.000 & 0.001 & 0.002 & 0.006 & 0.148 \\
UNCCOMMON & 16767 & 0.209 & 0.512 & -0.493 & -0.124 & 0.040 & 0.667 & 1.000 \\
POST & 16767 & 0.509 & 0.500 & 0.000 & 0.000 & 1.000 & 1.000 & 1.000 \\
TREAT & 16767 & 0.735 & 0.441 & 0.000 & 0.000 & 1.000 & 1.000 & 1.000 \\
LOGMCAP & 16767 & 6.465 & 1.738 & 3.678 & 5.249 & 6.377 & 7.615 & 9.602 \\
GROWTH & 16767 & 0.019 & 0.159 & -0.207 & -0.040 & 0.013 & 0.064 & 0.248 \\
LOGSEGMENTS & 16767 & 0.513 & 0.664 & 0.000 & 0.000 & 0.000 & 1.099 & 1.609 \\
PINST & 16767 & 0.668 & 0.279 & 0.151 & 0.463 & 0.722 & 0.883 & 1.054 \\
MFCOUNT & 16767 & 0.648 & 1.117 & 0.000 & 0.000 & 0.000 & 1.000 & 3.000 \\
NEWS & 16767 & 0.057 & 0.060 & 0.004 & 0.017 & 0.037 & 0.073 & 0.178 \\
SGA & 16767 & 0.275 & 0.243 & 0.000 & 0.063 & 0.230 & 0.433 & 0.763 \\
PASTSTDRET & 16767 & 0.043 & 0.027 & 0.014 & 0.024 & 0.035 & 0.054 & 0.099 \\
PREDERIV & 16767 & 0.368 & 0.276 & 0.060 & 0.146 & 0.299 & 0.523 & 0.911 \\
\hline Pa
\end{tabular}

Panel A presents descriptive statistics for the regression variables used in the SPREAD and STDRET regressions (following Bens et al., 2015). Panel B presents descriptive statistics for the regression variables used in the ACCURACY, DISPERSION, UNCTOTAL, and UNCCOMMON regressions (following Lehavy et al., 2011). All continuous variables are winsorized at $1 \%$ and $99 \%$, and variable definitions are provided in Appendix B. 
Table C. 4

Effect of SFAS 161 on SPREAD and STDRET

\begin{tabular}{|c|c|c|c|}
\hline & $\begin{array}{l}\text { Predicted } \\
\text { Sign }\end{array}$ & $\begin{array}{c}\text { Equation (1): } \\
\text { SPREAD }\end{array}$ & $\begin{array}{c}\text { Equation (1): } \\
\text { STDRET }\end{array}$ \\
\hline$\overline{\mathrm{POST}}$ & & $\begin{array}{l}-0.288^{* * *} \\
(-19.344)\end{array}$ & $\begin{array}{l}-0.017 \text { *** } \\
(-32.768)\end{array}$ \\
\hline TREAT & & $\begin{array}{l}0.035 \text { * } \\
(1.694)\end{array}$ & $\begin{array}{l}0.002 \text { *** } \\
(3.078)\end{array}$ \\
\hline POSTxTREAT & - & $\begin{array}{l}-0.069 \text { *** } \\
(-4.040)\end{array}$ & $\begin{array}{l}-0.002 \text { *** } \\
(-3.678)\end{array}$ \\
\hline $\mathrm{ROA}$ & - & $\begin{array}{r}-0.104 \\
(-1.019)\end{array}$ & $\begin{array}{l}-0.057 \text { *** } \\
(-12.919)\end{array}$ \\
\hline LEV & + & $\begin{array}{l}0.467 \text { *** } \\
(11.987)\end{array}$ & $\begin{array}{l}0.020^{* * *} \\
(14.711)\end{array}$ \\
\hline BTM & + & $\begin{array}{l}0.176^{* * *} \\
(20.013)\end{array}$ & $\begin{array}{l}0.007^{* * *} \\
(21.628)\end{array}$ \\
\hline SIZE & - & $\begin{array}{l}-0.229 \text { *** } \\
(-29.125)\end{array}$ & $\begin{array}{l}-0.002 \text { *** } \\
(-9.102)\end{array}$ \\
\hline PRICE & - & $\begin{array}{l}-0.005^{* * *} \\
(-6.603)\end{array}$ & $\begin{array}{l}-0.000 \text { *** } \\
(-16.211)\end{array}$ \\
\hline TURNOVER & $-/+$ & $\begin{array}{l}-0.427^{* * *} \\
(-53.755)\end{array}$ & $\begin{array}{l}0.007^{* * *} \\
(20.253)\end{array}$ \\
\hline FOLLOW & - & $\begin{array}{l}-0.192 \text { *** } \\
(-15.615)\end{array}$ & $\begin{array}{l}-0.004 \text { *** } \\
(-9.420)\end{array}$ \\
\hline PREDERIV & & $\begin{array}{r}0.016 \\
(0.454)\end{array}$ & $\begin{array}{r}0.001 \\
(0.460)\end{array}$ \\
\hline PASTSTDRET & + & $\begin{array}{l}10.042^{* * *} \\
(41.687)\end{array}$ & \\
\hline TRADESIZE & + & $\begin{array}{c}0.002^{* * *} \\
(30.381)\end{array}$ & \\
\hline Industry fixed effects & & Yes & Yes \\
\hline $\mathrm{N}$ & & 20623 & 20623 \\
\hline Adj. $R^{2}$ & & 0.859 & 0.371 \\
\hline \multicolumn{4}{|c|}{$\begin{array}{l}\text { This table presents results of estimating the effect of SFAS } 161 \text { adoption on uncertainty proxies based on } \\
\text { Bens et al. (2015). The dependent variable in the first column is SPREAD: the natural log of the average } \\
\text { daily bid-ask spread during the calendar month following the } 10-\mathrm{Q} \text { or } 10-\mathrm{K} \text { filing date. The dependent } \\
\text { variable in the second column is STDRET: the standard deviation of daily returns during the calendar } \\
\text { month following the } 10-\mathrm{Q} \text { or } 10-\mathrm{K} \text { filing date. Variable definitions are provided in Appendix B. All } \\
\text { continuous variables are winsorized at } 1 \% \text { and } 99 \% \text {. Standard errors are heteroskedasticity-robust and } \\
\text { clustered by firm. t-statistics are reported in parentheses, and statistical significance based on one-tailed } \\
\text { tests for variables with predicted signs (two-tailed otherwise) is indicated by } * \text { for } p<0.10 \text {; } * * \text { for } p< \\
0.05 \text {; and } * * * \text { for } p<0.01 \text {. }\end{array}$} \\
\hline
\end{tabular}


Table C.5

Effect of SFAS 161 on ACCURACY, DISPERSION, UNCTOTAL, and UNCCOMMON

\begin{tabular}{|c|c|c|c|c|c|}
\hline & $\begin{array}{c}\text { Predicted } \\
\text { Sign } \\
\end{array}$ & $\begin{array}{l}\text { Equation (1): } \\
\text { ACCURACY }\end{array}$ & $\begin{array}{l}\text { Equation (1): } \\
\text { DISPERSION }\end{array}$ & $\begin{array}{l}\text { Equation (1): } \\
\text { UNCTOTAL }\end{array}$ & $\begin{array}{c}\text { Equation (1): } \\
\text { UNCCOMMON }\end{array}$ \\
\hline$\overline{\mathrm{POST}}$ & & $\begin{array}{l}0.080^{* * *} \\
(5.936)\end{array}$ & $\begin{array}{l}0.005 \text { *** } \\
(6.215)\end{array}$ & $\begin{array}{l}0_{0.091}^{* * *} \\
(6.132)\end{array}$ & $\begin{array}{c}0.027^{*} \\
(1.676)\end{array}$ \\
\hline TREAT & + & $\begin{array}{l}0.050 \text { ** } \\
(2.200)\end{array}$ & $\begin{array}{r}0.001 \\
(0.936)\end{array}$ & $\begin{array}{l}0.055 \text { ** } \\
(2.088)\end{array}$ & $\begin{array}{l}0.054 \text { *** } \\
(2.858)\end{array}$ \\
\hline POSTxTREAT & - & $\begin{array}{l}-0.038 * * * \\
(-2.415)\end{array}$ & $\begin{array}{r}-0.000 \\
(-0.371)\end{array}$ & $\begin{array}{l}-0.040 * * * \\
(-2.344)\end{array}$ & $\begin{array}{l}-0.032 \text { ** } \\
(-1.817)\end{array}$ \\
\hline LOGMCAP & - & $\begin{array}{l}-0.023 \text { *** } \\
(-3.601)\end{array}$ & $\begin{array}{l}-0.002 \text { *** } \\
(-5.057)\end{array}$ & $\begin{array}{l}-0.026 \text { *** } \\
(-3.665)\end{array}$ & $\begin{array}{l}-0.028^{* * *} \\
(-6.137)\end{array}$ \\
\hline GROWTH & & $\begin{array}{r}0.004 \\
(0.079)\end{array}$ & $\begin{array}{r}-0.000 \\
(-0.128)\end{array}$ & $\begin{array}{r}0.007 \\
(0.108)\end{array}$ & $\begin{array}{r}0.021 \\
(0.775)\end{array}$ \\
\hline LOGSEGMENTS & + & $\begin{array}{l}0.032 \text { ** } \\
(1.963)\end{array}$ & $\begin{array}{r}-0.000 \\
(-0.411)\end{array}$ & $\begin{array}{l}0.035 \text { ** } \\
(1.933)\end{array}$ & $\begin{array}{l}0.036^{* * *} \\
(3.521)\end{array}$ \\
\hline PINST & & $\begin{array}{l}-0.097 \text { ** } \\
(-1.998)\end{array}$ & $\begin{array}{r}-0.001 \\
(-0.548)\end{array}$ & $\begin{array}{c}-0.105 * \\
(-1.929)\end{array}$ & $\begin{array}{l}-0.2000^{* * *} \\
(-7.182)\end{array}$ \\
\hline MFCOUNT & & $\begin{array}{r}0.001 \\
(0.155)\end{array}$ & $\begin{array}{l}-0.001 \text { *** } \\
(-3.599)\end{array}$ & $\begin{array}{r}-0.000 \\
(-0.027)\end{array}$ & $\begin{array}{r}-0.006 \\
(-1.370)\end{array}$ \\
\hline NEWS & + & $\begin{array}{l}0.666 \text { *** } \\
(3.287)\end{array}$ & $\begin{array}{l}0.041 \text { *** } \\
(4.609)\end{array}$ & $\begin{array}{l}0.774 \text { *** } \\
(3.403)\end{array}$ & $\begin{array}{l}0.1399^{* *} \\
(1.651)\end{array}$ \\
\hline SGA & & $\begin{array}{r}-0.085 \\
(-1.394)\end{array}$ & $\begin{array}{l}-0.007 \text { ** } \\
(-2.348)\end{array}$ & $\begin{array}{r}-0.095 \\
(-1.320)\end{array}$ & $\begin{array}{r}-0.033 \\
(-0.953)\end{array}$ \\
\hline PASTSTDRET & + & $\begin{array}{l}4.351 \text { *** } \\
(7.456)\end{array}$ & $\begin{array}{l}0.266 \text { *** } \\
(9.378)\end{array}$ & $\begin{array}{l}4.880 \text { *** } \\
(7.540)\end{array}$ & $\begin{array}{l}1.460 \text { *** } \\
(7.327)\end{array}$ \\
\hline PREDERIV & + & $\begin{array}{l}0.1300^{* * *} \\
(2.496)\end{array}$ & $\begin{array}{l}0.008 \text { *** } \\
(3.083)\end{array}$ & $\begin{array}{l}0.148^{* * *} \\
(2.539)\end{array}$ & $\begin{array}{r}-0.003 \\
(-0.101)\end{array}$ \\
\hline \multicolumn{2}{|c|}{ Industry fixed effects } & Yes & Yes & Yes & Yes \\
\hline \multicolumn{2}{|l|}{$\mathrm{N}$} & 16767 & 16767 & 16767 & 16767 \\
\hline \multicolumn{2}{|l|}{ Adj. $R^{2}$} & 0.071 & 0.111 & 0.073 & 0.075 \\
\hline
\end{tabular}

This table presents results of estimating the effect of SFAS 161 adoption on uncertainty proxies based on Lehavy et al. (2011). The dependent variable in the first column is ACCURACY: the squared difference between the IBES actual earnings and the first consensus forecast for quarter $t+1$ following the $10-\mathrm{Q}$ or $10-\mathrm{K}$ filing date for quarter $t$. The dependent variable in the second column is DISPERSION: the standard deviation of the forecasts comprising the first consensus forecast for quarter $t+1$ following the 10-Q or 10-K filing date for quarter $t$. The dependent variable in columns three and four are UNCTOTAL and UNCCOMMON: analysts' total and common uncertainty following Lehavy et al.'s (2011) implementation of Barron et al.'s (1998) equations (15) and (16). Variable definitions are provided in Appendix B. All continuous variables are winsorized at $1 \%$ and $99 \%$. Standard errors are heteroskedasticity-robust and clustered by firm. $t$-statistics are reported in parentheses, and statistical significance based on one-tailed tests for variables with predicted signs (two-tailed otherwise) is indicated by * for $p<0.10$;** for $p<0.05$; and ${ }^{* * *}$ for $p<0.01$. 
Table C.6

Effects of SFAS 161 Disclosure Characteristics on SPREAD and STDRE

Panel A: Equation (2) with dependent variable $=$ SPREAD

\begin{tabular}{|c|c|c|c|c|c|c|c|}
\hline Disclosure characteristic (DISCVAR): & $\begin{array}{c}\text { Predicted } \\
\text { Sign }\end{array}$ & $\Delta$ WORDS & $\Delta$ NUMS & $\triangle$ GROUP & $\triangle$ TABNUMS & $\triangle$ WPERNUM & DFACTOR \\
\hline $\begin{array}{l}\text { POST } \\
\end{array}$ & & $\begin{array}{c}-0.288 \text { *** } \\
(-19.323)\end{array}$ & $\begin{array}{c}-0.288^{* * *} \\
(-19.345)\end{array}$ & $\begin{array}{l}-0.288 \text { *** } \\
(-19.340)\end{array}$ & $\begin{array}{c}-0.288 \text { *** } \\
(-19.346)\end{array}$ & $\begin{array}{c}-0.288^{* * *} \\
(-19.348)\end{array}$ & $\begin{array}{l}-0.288 \text { *** } \\
(-19.336)\end{array}$ \\
\hline TREAT & & $\begin{array}{r}0.028 \\
(1.339)\end{array}$ & $\begin{array}{r}0.024 \\
(1.171)\end{array}$ & $\begin{array}{r}0.034 \\
(1.625)\end{array}$ & $\begin{array}{r}0.033 \\
(1.577)\end{array}$ & $\begin{array}{c}0.035 \text { * } \\
(1.670)\end{array}$ & $\begin{array}{r}0.024 \\
(1.166)\end{array}$ \\
\hline POSTxTREAT & - & $\begin{array}{l}-0.050 \text { *** } \\
(-2.907)\end{array}$ & $\begin{array}{l}-0.039 \text { ** } \\
(-2.186)\end{array}$ & $\begin{array}{l}-0.068 \text { *** } \\
(-3.968)\end{array}$ & $\begin{array}{l}-0.050 \text { *** } \\
(-2.839)\end{array}$ & $\begin{array}{l}-0.074 \text { *** } \\
(-4.280)\end{array}$ & $\begin{array}{l}-0.060 \text { *** } \\
(-3.504)\end{array}$ \\
\hline POSTxTREATxDISCVAR & & $\begin{array}{l}-0.375 \text { *** } \\
(-6.982)\end{array}$ & $\begin{array}{l}-0.584 \text { *** } \\
(-6.725)\end{array}$ & $\begin{array}{l}-0.004 \text { ** } \\
(-2.189)\end{array}$ & $\begin{array}{l}-0.002 \text { *** } \\
(-4.000)\end{array}$ & $\begin{array}{l}-0.006 \text { ** } \\
(-1.841)\end{array}$ & $\begin{array}{l}-0.0655^{* * *} \\
(-7.831)\end{array}$ \\
\hline ROA & - & $\begin{array}{r}-0.102 \\
(-0.999)\end{array}$ & $\begin{array}{r}-0.107 \\
(-1.053)\end{array}$ & $\begin{array}{r}-0.103 \\
(-1.013)\end{array}$ & $\begin{array}{r}-0.105 \\
(-1.036)\end{array}$ & $\begin{array}{r}-0.107 \\
(-1.050)\end{array}$ & $\begin{array}{r}-0.105 \\
(-1.039)\end{array}$ \\
\hline LEV & + & $\begin{array}{c}0.471 \text { *** } \\
(12.124)\end{array}$ & $\begin{array}{c}0.469 \text { *** } \\
(12.049)\end{array}$ & $\begin{array}{l}0.466 \text { *** } \\
(11.967)\end{array}$ & $\begin{array}{l}0.466 \text { *** } \\
(11.998)\end{array}$ & $\begin{array}{c}0.467 \text { *** } \\
(12.019)\end{array}$ & $\begin{array}{l}0.470 \text { *** } \\
(12.103)\end{array}$ \\
\hline BTM & + & $\begin{array}{l}0.175 \text { *** } \\
(19.883)\end{array}$ & $\begin{array}{c}0.1766^{* * *} \\
(19.977)\end{array}$ & $\begin{array}{l}0.176 \text { *** } \\
(20.000)\end{array}$ & $\begin{array}{l}0.176 \text { *** } \\
(19.985)\end{array}$ & $\begin{array}{l}0.176 \text { *** } \\
(20.042)\end{array}$ & $\begin{array}{l}0.175^{* * *} \\
(19.911)\end{array}$ \\
\hline SIZE & - & $\begin{array}{l}-0.226 \text { *** } \\
(-28.937)\end{array}$ & $\begin{array}{l}-0.227 \text { *** } \\
(-29.020)\end{array}$ & $\begin{array}{l}-0.228 \text { *** } \\
(-28.965)\end{array}$ & $\begin{array}{l}-0.228 \text { *** } \\
(-29.147)\end{array}$ & $\begin{array}{l}-0.229 \text { *** } \\
(-29.141)\end{array}$ & $\begin{array}{l}-0.226 \text { *** } \\
(-29.000)\end{array}$ \\
\hline PRICE & - & $\begin{array}{l}-0.005 * * * \\
(-6.513)\end{array}$ & $\begin{array}{l}-0.005 \text { *** } \\
(-6.547)\end{array}$ & $\begin{array}{l}-0.005 \text { *** } \\
(-6.625)\end{array}$ & $\begin{array}{l}-0.005 \text { *** } \\
(-6.573)\end{array}$ & $\begin{array}{l}-0.005 \text { *** } \\
(-6.602)\end{array}$ & $\begin{array}{l}-0.0055^{* * *} \\
(-6.507)\end{array}$ \\
\hline TURNOVER & - & $\begin{array}{c}-0.429 \text { *** } \\
(-54.132)\end{array}$ & $\begin{array}{c}-0.429^{* * *} \\
(-54.104)\end{array}$ & $\begin{array}{c}-0.427 \text { *** } \\
(-53.759)\end{array}$ & $\begin{array}{c}-0.427 \text { *** } \\
(-53.840)\end{array}$ & $\begin{array}{l}-0.427 \text { *** } \\
(-53.734)\end{array}$ & $\begin{array}{c}-0.429 \text { *** } \\
(-54.184)\end{array}$ \\
\hline FOLLOW & - & $\begin{array}{l}-0.192 \text { *** } \\
(-15.577)\end{array}$ & $\begin{array}{c}-0.1922^{* * *} \\
(-15.562)\end{array}$ & $\begin{array}{c}-0.1933^{\text {*** }} \\
(-15.631)\end{array}$ & $\begin{array}{c}-0.1922^{\text {*** }} \\
(-15.565)\end{array}$ & $\begin{array}{l}-0.1922^{* * *} \\
(-15.592)\end{array}$ & $\begin{array}{l}-0.191 \text { *** } \\
(-15.536)\end{array}$ \\
\hline PREDERIV & & $\begin{array}{r}0.034 \\
(0.984)\end{array}$ & $\begin{array}{r}0.048 \\
(1.375)\end{array}$ & $\begin{array}{r}0.020 \\
(0.576)\end{array}$ & $\begin{array}{r}0.023 \\
(0.661)\end{array}$ & $\begin{array}{r}0.018 \\
(0.506)\end{array}$ & $\begin{array}{r}0.047 \\
(1.335)\end{array}$ \\
\hline PASTSTDRET & + & $\begin{array}{l}10.046 \text { *** } \\
(41.774)\end{array}$ & $\begin{array}{l}10.033 \text { *** } \\
(41.759)\end{array}$ & $\begin{array}{l}10.042 \text { *** } \\
(41.712)\end{array}$ & $\begin{array}{l}10.038 \text { *** } \\
(41.677)\end{array}$ & $\begin{array}{l}10.040 \text { *** } \\
(41.696)\end{array}$ & $\begin{array}{l}10.036 \text { *** } \\
(41.766)\end{array}$ \\
\hline TRADESIZE & + & $\begin{array}{c}0.002 \text { *** } \\
(30.417) \\
\end{array}$ & $\begin{array}{c}0.002 * * * \\
(30.490) \\
\end{array}$ & $\begin{array}{c}0.002 \text { *** } \\
(30.407) \\
\end{array}$ & $\begin{array}{c}0.002 * * * \\
(30.403) \\
\end{array}$ & $\begin{array}{c}0.002 \text { *** } \\
(30.382) \\
\end{array}$ & $\begin{array}{c}0.002 * * * \\
(30.475)\end{array}$ \\
\hline Industry fixed effects & & Yes & Yes & Yes & Yes & Yes & Yes \\
\hline $\mathrm{N}$ & & 20623 & 20623 & 20623 & 20623 & 20623 & 20623 \\
\hline Adj. $R^{2}$ & & 0.860 & 0.859 & 0.859 & 0.859 & 0.859 & 0.860 \\
\hline
\end{tabular}


Panel B: Equation (2) with dependent variable $=$ STDRET

\begin{tabular}{|c|c|c|c|c|c|c|c|}
\hline Disclosure characteristic (DISCVAR): & $\begin{array}{l}\text { Predicted } \\
\text { Sign }\end{array}$ & $\Delta$ WORDS & $\Delta$ NUMS & $\Delta$ GROUP & $\triangle \mathrm{TABNUMS}$ & $\triangle$ WPERNUM & DFACTOR \\
\hline POST & & $\begin{array}{c}-0.017 \text { *** } \\
(-32.766)\end{array}$ & $\begin{array}{c}-0.017 \text { *** } \\
(-32.768)\end{array}$ & $\begin{array}{l}-0.017 \text { *** } \\
(-32.767)\end{array}$ & $\begin{array}{c}-0.017 \text { *** } \\
(-32.767)\end{array}$ & $\begin{array}{l}-0.017 \text { *** } \\
(-32.765)\end{array}$ & $\begin{array}{l}-0.017 \text { *** } \\
(-32.767)\end{array}$ \\
\hline TREAT & & $\begin{array}{l}0.002 \text { *** } \\
(3.114)\end{array}$ & $\begin{array}{l}0.002 \text { *** } \\
(2.987)\end{array}$ & $\begin{array}{l}0.002 \text { *** } \\
(3.077)\end{array}$ & $\begin{array}{l}0.002 \text { *** } \\
(3.062)\end{array}$ & $\begin{array}{l}0.002 \text { *** } \\
(3.061)\end{array}$ & $\begin{array}{l}0.002 \text { *** } \\
(3.053)\end{array}$ \\
\hline POSTxTREAT & - & $\begin{array}{l}-0.002 * * * \\
(-3.737)\end{array}$ & $\begin{array}{l}-0.002 * * * \\
(-3.286)\end{array}$ & $\begin{array}{l}-0.002 * * * \\
(-3.675)\end{array}$ & $\begin{array}{l}-0.002 \text { *** } \\
(-3.451)\end{array}$ & $\begin{array}{l}-0.002 * * * \\
(-3.849)\end{array}$ & $\begin{array}{l}-0.002 * * * \\
(-3.646)\end{array}$ \\
\hline POSTxTREATxDISCVAR & - & $\begin{array}{r}0.001 \\
(0.751)\end{array}$ & $\begin{array}{r}-0.003 \\
(-1.124)\end{array}$ & $\begin{array}{r}0.000 \\
(0.032)\end{array}$ & $\begin{array}{r}-0.000 \\
(-0.486)\end{array}$ & $\begin{array}{c}-0.000 * \\
(-1.382)\end{array}$ & $\begin{array}{r}-0.000 \\
(-0.348)\end{array}$ \\
\hline ROA & - & $\begin{array}{c}-0.057 \text { *** } \\
(-12.918)\end{array}$ & $\begin{array}{l}-0.057 \text { *** } \\
(-12.922)\end{array}$ & $\begin{array}{l}-0.057 \text { *** } \\
(-12.918)\end{array}$ & $\begin{array}{c}-0.057^{* * *} \\
(-12.922)\end{array}$ & $\begin{array}{c}-0.057 \text { *** } \\
(-12.925)\end{array}$ & $\begin{array}{l}-0.057 \text { *** } \\
(-12.919)\end{array}$ \\
\hline LEV & + & $\begin{array}{c}0.020 \text { *** } \\
(14.678)\end{array}$ & $\begin{array}{c}0.020 \text { *** } \\
(14.722)\end{array}$ & $\begin{array}{c}0.020 \text { *** } \\
(14.710)\end{array}$ & $\begin{array}{c}0.020 \text { *** } \\
(14.709)\end{array}$ & $\begin{array}{c}0.020 \text { *** } \\
(14.736)\end{array}$ & $\begin{array}{c}0.020 \text { *** } \\
(14.713)\end{array}$ \\
\hline BTM & + & $\begin{array}{l}0.007 \text { *** } \\
(21.663)\end{array}$ & $\begin{array}{l}0.007 \text { *** } \\
(21.625)\end{array}$ & $\begin{array}{l}0.007 \text { *** } \\
(21.617)\end{array}$ & $\begin{array}{l}0.007 \text { *** } \\
(21.642)\end{array}$ & $\begin{array}{l}0.007 \text { *** } \\
(21.655)\end{array}$ & $\begin{array}{l}0.007^{* * *} \\
(21.635)\end{array}$ \\
\hline SIZE & - & $\begin{array}{l}-0.002 * * * \\
(-9.127)\end{array}$ & $\begin{array}{l}-0.002 \text { *** } \\
(-9.047)\end{array}$ & $\begin{array}{l}-0.002 * * * \\
(-9.092)\end{array}$ & $\begin{array}{l}-0.002 \text { *** } \\
(-9.095)\end{array}$ & $\begin{array}{l}-0.002 * * * \\
(-9.113)\end{array}$ & $\begin{array}{l}-0.002 * * * \\
(-9.073)\end{array}$ \\
\hline PRICE & - & $\begin{array}{c}-0.000 \text { *** } \\
(-16.187)\end{array}$ & $\begin{array}{l}-0.000 \text { *** } \\
(-16.205)\end{array}$ & $\begin{array}{l}-0.000 \text { *** } \\
(-16.210)\end{array}$ & $\left.{ }_{(-16.204)}^{-0.000}\right)^{* * *}$ & $\begin{array}{l}-0.000 \\
(-16.212)\end{array}$ & $\begin{array}{l}-0.000 \text { *** } \\
(-16.188)\end{array}$ \\
\hline TURNOVER & + & $\begin{array}{c}0.007 \text { *** } \\
(20.218)\end{array}$ & $\begin{array}{c}0.007 \text { *** } \\
(20.215)\end{array}$ & $\begin{array}{c}0.007 \text { *** } \\
(20.263)\end{array}$ & $\begin{array}{c}0.007 \text { *** } \\
(20.240)\end{array}$ & $\begin{array}{c}0.007 \text { *** } \\
(20.245)\end{array}$ & $\begin{array}{c}0.007 \text { *** } \\
(20.198)\end{array}$ \\
\hline FOLLOW & - & $\begin{array}{l}-0.004 * * * \\
(-9.424)\end{array}$ & $\begin{array}{l}-0.004 \text { *** } \\
(-9.414)\end{array}$ & $\begin{array}{l}-0.004 \text { *** } \\
(-9.416)\end{array}$ & $\begin{array}{l}-0.004 \text { *** } \\
(-9.405)\end{array}$ & $\begin{array}{l}-0.004 \text { *** } \\
(-9.398)\end{array}$ & $\begin{array}{l}-0.004 * * * \\
(-9.411)\end{array}$ \\
\hline PREDERIV & & $\begin{array}{r}0.000 \\
(0.406) \\
\end{array}$ & $\begin{array}{r}0.001 \\
(0.601) \\
\end{array}$ & $\begin{array}{r}0.001 \\
(0.458) \\
\end{array}$ & $\begin{array}{r}0.001 \\
(0.484) \\
\end{array}$ & $\begin{array}{r}0.001 \\
(0.500) \\
\end{array}$ & $\begin{array}{r}0.001 \\
(0.495) \\
\end{array}$ \\
\hline Industry fixed effects & & Yes & Yes & Yes & Yes & Yes & Yes \\
\hline $\mathrm{N}$ & & 20623 & 20623 & 20623 & 20623 & 20623 & 20623 \\
\hline Adj. $R^{2}$ & & 0.371 & 0.371 & 0.371 & 0.371 & 0.371 & 0.371 \\
\hline $\begin{array}{l}\text { This table presents estimation models } \\
\text { effect on SPREAD and STDRET of va } \\
\text { in the table), DISCVAR can take the v } \\
\text { Panel A presents estimation results for } \\
\text { provided in Appendix B. All continuc } \\
\text { parentheses, and statistical significance } \\
0.01 \text {. }\end{array}$ & $\begin{array}{l}\text { identical to } \\
\text { rariation in } t \\
\text { value of } \Delta W \\
\text { or SPREAD } \\
\text { uous variable } \\
\text { e based on o }\end{array}$ & $\begin{array}{l}\text { sse presented in } \\
\text { ndividual disclos } \\
\text { DS, } \Delta \text { NUMS, } \\
\text { the dependent v } \\
\text { re winsorized at } \\
\text { tailed tests for vi }\end{array}$ & $\begin{array}{l}\text { C.4 except for th } \\
\text { aracteristic varial } \\
\text { UP, } \triangle \text { TABNUMS } \\
\text { e, and Panel B p } \\
\text { and } 99 \% \text {. Standa } \\
\text { es with predicted }\end{array}$ & $\begin{array}{l}\text { dition of the PO } \\
\text { for treatmeant fil } \\
\text { NPERNUM, or I } \\
\text { its estimation re } \\
\text { rrors are hetero: } \\
\text { (two-tailed othe }\end{array}$ & $\begin{array}{l}\text { REATxDISCVAR } \\
\text { epending on the s } \\
\text { TOR (see Table C. } \\
\text { or STDRET as th } \\
\text { ticity-robust and } \\
\text { is indicated by * }\end{array}$ & $\begin{array}{l}\text { ble. This additiol } \\
\text { fication (indicated } \\
\mathrm{r} \text { descriptive stati: } \\
\text { ependent variable. } \\
\text { ered by firm. } t-\mathrm{s} \\
0<0.10 ; * \text { for } p\end{array}$ & $\begin{array}{l}\text { riable captures the } \\
\text { e column headings } \\
\mathrm{n} \text { these measures). } \\
\text { ble definitions are } \\
\text { cs are reported in } \\
5 \text {; and }{ }^{* * *} \text { for } p<\end{array}$ \\
\hline
\end{tabular}


Table C.7

Effects of SFAS 161 Disclosure Characteristics on ACCURACY, DISPERSION, UNCTOTAL, and UNCCOMMON

Panel A: Equation (2) with dependent variable $=$ ACCURACY

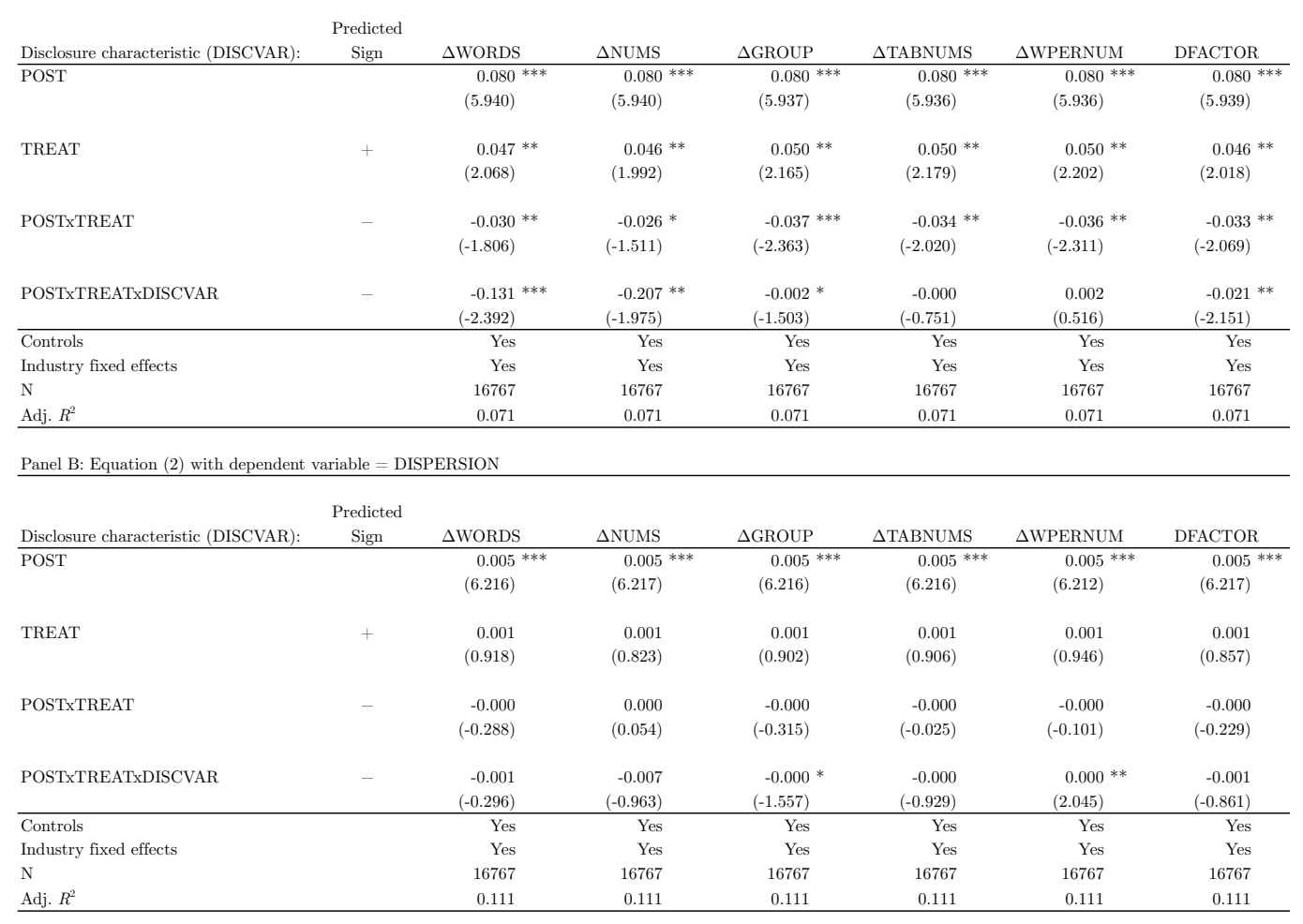


Panel C: Equation (2) with dependent variable $=$ UNCTOTAL

\begin{tabular}{|c|c|c|c|c|c|c|c|}
\hline Disclosure characteristic (DISCVAR): & $\begin{array}{l}\text { Predicted } \\
\text { Sign }\end{array}$ & $\Delta$ WORDS & $\triangle$ NUMS & $\triangle$ GROUP & $\triangle$ TABNUMS & $\triangle$ WPERNUM & DFACTOR \\
\hline POST & & $\begin{array}{l}0.0922^{* * * *} \\
(6.135)\end{array}$ & $\begin{array}{l}0.0922^{* * *} \\
(6.135)\end{array}$ & $\begin{array}{c}0.0911^{* * *} \\
(6.132)\end{array}$ & $\begin{array}{l}0.0911^{* * *} \\
(6.131)\end{array}$ & $\begin{array}{l}0.0911^{* * * *} \\
(6.131)\end{array}$ & $\begin{array}{l}0.092^{* * *} \\
(6.135)\end{array}$ \\
\hline TREAT & + & $\begin{array}{c}0.051 \text { ** } \\
(1.962)\end{array}$ & $\begin{array}{c}0.050 \text { ** } \\
(1.885)\end{array}$ & $\begin{array}{c}0.054 \text { ** } \\
(2.052)\end{array}$ & $\begin{array}{l}0.054 \text { ** } \\
(2.062)\end{array}$ & $\begin{array}{l}0.055 \text { ** } \\
(2.090)\end{array}$ & $\begin{array}{l}0.050 \text { ** } \\
(1.907)\end{array}$ \\
\hline POSTxTREAT & - & $\begin{array}{l}-0.032 \text { ** } \\
(-1.734)\end{array}$ & $\begin{array}{c}-0.027 * \\
(-1.427)\end{array}$ & $\begin{array}{l}-0.039 \text { ** } \\
(-2.286)\end{array}$ & $\begin{array}{l}-0.035 \text { ** } \\
(-1.876)\end{array}$ & $\begin{array}{l}-0.038 \text { ** } \\
(-2.233)\end{array}$ & $\begin{array}{l}-0.035 \text { ** } \\
(-1.985)\end{array}$ \\
\hline POSTxTREATxDISCVAR & - & $\begin{array}{c}-0.1433^{* *} \\
(-2.298)\end{array}$ & $\begin{array}{c}-0.231 \text { ** } \\
(-1.973)\end{array}$ & $\begin{array}{c}-0.002 * \\
(-1.607) \\
\end{array}$ & $\begin{array}{r}-0.000 \\
(-0.871) \\
\end{array}$ & $\begin{array}{r}0.002 \\
(0.598) \\
\end{array}$ & $\begin{array}{l}-0.024 \text { ** } \\
(-2.150)\end{array}$ \\
\hline Controls & & Yes & Yes & Yes & Yes & Yes & Yes \\
\hline Industry fixed effects & & Yes & Yes & Yes & Yes & Yes & Yes \\
\hline $\mathrm{N}$ & & 16767 & 16767 & 16767 & 16767 & 16767 & 16767 \\
\hline Adj. $R^{2}$ & & 0.074 & 0.074 & 0.073 & 0.073 & 0.073 & 0.074 \\
\hline \multicolumn{8}{|c|}{ Panel D: Equation (2) with dependent variable = UNCCOMMON } \\
\hline Disclosure characteristic (DISCVAR): & $\begin{array}{l}\text { Predicted } \\
\text { Sign }\end{array}$ & $\Delta$ WORDS & $\triangle$ NUMS & $\triangle$ GROUP & $\triangle$ TABNUMS & $\triangle$ WPERNUM & DFACTOR \\
\hline POST & & $\begin{array}{c}0.027 * \\
(1.677)\end{array}$ & $\begin{array}{c}0.027 * \\
(1.677)\end{array}$ & $\begin{array}{c}0.027 * \\
(1.675)\end{array}$ & $\begin{array}{c}0.027 * \\
(1.676)\end{array}$ & $\begin{array}{c}0.027 \text { * } \\
(1.678)\end{array}$ & $\begin{array}{c}0.027 * \\
(1.677)\end{array}$ \\
\hline TREAT & + & $\begin{array}{l}0.053 \text { *** } \\
(2.815)\end{array}$ & $\begin{array}{l}0.053 * * * \\
(2.814)\end{array}$ & $\begin{array}{l}0.054 * * * \\
(2.876)\end{array}$ & $\begin{array}{l}0.053 \text { *** } \\
(2.839)\end{array}$ & $\begin{array}{l}0.054 \text { *** } \\
(2.852)\end{array}$ & $\begin{array}{l}0.053 \text { *** } \\
(2.796)\end{array}$ \\
\hline POSTxTREAT & - & $\begin{array}{c}-0.030 \\
(-1.654)\end{array}$ & $\begin{array}{c}-0.030 \\
(-1.640)\end{array}$ & $\begin{array}{c}-0.033 \text { ** } \\
(-1.837)\end{array}$ & $\begin{array}{c}-0.030 \\
(-1.614)\end{array}$ & $\begin{array}{c}-0.034 \text { ** } \\
(-1.905)\end{array}$ & $\begin{array}{l}-0.031 \text { ** } \\
(-1.728)\end{array}$ \\
\hline POSTxTREATxDISCVAR & - & $\begin{array}{r}-0.039 \\
(-0.842) \\
\end{array}$ & $\begin{array}{r}-0.036 \\
(-0.480) \\
\end{array}$ & $\begin{array}{r}0.001 \\
(0.514) \\
\end{array}$ & $\begin{array}{r}-0.000 \\
(-0.551) \\
\end{array}$ & $\begin{array}{r}-0.002 \\
(-0.849) \\
\end{array}$ & $\begin{array}{r}-0.006 \\
(-0.817) \\
\end{array}$ \\
\hline Controls & & Yes & Yes & Yes & Yes & Yes & Yes \\
\hline Industry fixed effects & & Yes & Yes & Yes & Yes & Yes & Yes \\
\hline $\mathrm{N}$ & & 16767 & 16767 & 16767 & 16767 & 16767 & 16767 \\
\hline Adj. $R^{2}$ & & 0.075 & 0.075 & 0.075 & 0.075 & 0.075 & 0.075 \\
\hline $\begin{array}{l}\text { This table presents estimation model } \\
\text { variable captures the effect on ACCl } \\
\text { treatmeant firms. Depending on the } \\
\triangle \text { TABNUMS, } \triangle \text { WPERNUM, or DFA } \\
\text { ACCURACY as the dependent variab } \\
\text { results for equation (2) with UNCTO } \\
\text { control variables shown in Table } 5 \text { are } \\
\text { continuous variables are winsorized a } \\
\text { statistical significance based on one-ta } \\
0.01 \text {. }\end{array}$ & $\begin{array}{l}\text { dentical to } \\
\text { ACY, DISI } \\
\text { cification ( } \\
\text { TOR (see } \\
\text { Panel B pr } \\
\mathrm{L} \text { as the de } \\
\text { cluded in al } \\
\% \text { and } 99 \% \\
\text { d tests for }\end{array}$ & $\begin{array}{l}\text { Rose presented in } \\
\text { RSION, UNCTO } \\
\text { licated by the co } \\
\text { ble C.2 for descr } \\
\text { nts estimation re } \\
\text { ndent variable; ar } \\
\text { stimations in Tab } \\
\text { Standard errors a } \\
\text { iables with predi }\end{array}$ & $\begin{array}{l}\text { De C.5 except } \\
\text {, and UNCCO } \\
\text { headings in t1 } \\
\text { e statistics on } \\
\text { for equation ( } \\
\text { anel D presents } \\
\text { but they are n } \\
\text { beteroskedasticit } \\
\text { signs (two-taile }\end{array}$ & $\begin{array}{l}\text { the addition of } \\
\text { MON of variatio } \\
\text { table), DISCVA } \\
\text { ese measures). P } \\
\text { with DISPERSIC } \\
\text { sults for equation } \\
\text { presented for bre } \\
\text { obust and cluste } \\
\text { therwise) is indi }\end{array}$ & $\begin{array}{l}\text { the POSTxTREA? } \\
\text { in the individual } \\
\text { can take the valu } \\
\text { nel A presents est } \\
\text { as the dependent } \\
\text { (2) with UNCCOI } \\
\text { ity. Variable defin } \\
\text { ed by firm. } t \text {-stati } \\
\text { ated by * for } p<\end{array}$ & $\begin{array}{l}\text { xDISCVAR variab } \\
\text { disclosure characte } \\
\text { of } \Delta \text { WORDS, } \Delta \\
\text { mation results for } \\
\text { variable; Panel C } \\
\text { MON as the deper } \\
\text { ions are provided } \\
\text { tics are reported i } \\
10 ; * * \text { for } p<0.0\end{array}$ & $\begin{array}{l}\text { This additional } \\
\text { tic variables for } \\
\text { JMS, } \Delta \text { GROUP, } \\
\text { quation (2) with } \\
\text { sents estimation } \\
\text { int variable. The } \\
\text { Appendix B. All } \\
\text { parentheses, and } \\
\text { and *** for } p<\end{array}$ \\
\hline
\end{tabular}


Table C.8

Effect of SFAS 161 on the Association Between SPREAD and Risk Movement

\begin{tabular}{|c|c|c|c|c|c|c|c|c|}
\hline Disclosure characteristic (DISCVAR): & $\begin{array}{c}\text { Predicted } \\
\text { Sign }\end{array}$ & & $\Delta$ WORDS & $\Delta$ NUMS & $\triangle$ GROUP & $\triangle$ TABNUMS & $\triangle$ WPERNUM & DFACTOR \\
\hline DRISK & + & $\begin{array}{c}0.293 \text { *** } \\
(25.125)\end{array}$ & $\begin{array}{c}0.295 \text { *** } \\
(25.393)\end{array}$ & $\begin{array}{c}0.297 * * * \\
(25.608)\end{array}$ & $\begin{array}{c}0.293 \text { *** } \\
(25.176)\end{array}$ & $\begin{array}{c}0.294 \text { *** } \\
(25.223)\end{array}$ & $\begin{array}{c}0.293 \text { *** } \\
(25.127)\end{array}$ & $\begin{array}{c}0.297 \text { **** } \\
(25.588)\end{array}$ \\
\hline POSTxDRISK & & $\begin{array}{c}-0.249 * * * \\
(-28.098)\end{array}$ & $\begin{array}{c}-0.248 * * * \\
(-28.034)\end{array}$ & $\begin{array}{c}-0.248 * * * \\
(-27.966)\end{array}$ & $\begin{array}{c}-0.249 * * * \\
(-28.085)\end{array}$ & $\begin{array}{c}-0.249 \text { *** } \\
(-28.069)\end{array}$ & $\begin{array}{c}-0.249 \text { *** } \\
(-28.096)\end{array}$ & $\begin{array}{c}-0.248 \text { *** } \\
(-27.978)\end{array}$ \\
\hline TREATXDRISK & & $\begin{array}{r}0.015 \\
(1.264)\end{array}$ & $\begin{array}{r}0.012 \\
(1.028)\end{array}$ & $\begin{array}{r}0.010 \\
(0.851)\end{array}$ & $\begin{array}{r}0.015 \\
(1.222)\end{array}$ & $\begin{array}{r}0.014 \\
(1.152)\end{array}$ & $\begin{array}{r}0.015 \\
(1.252)\end{array}$ & $\begin{array}{r}0.010 \\
(0.856)\end{array}$ \\
\hline POSTxTREATXDRISK & - & $\begin{array}{l}-0.043 * * * \\
(-4.142)\end{array}$ & $\begin{array}{l}-0.032 \text { *** } \\
(-2.955)\end{array}$ & $\begin{array}{l}-0.021 \text { ** } \\
(-1.865)\end{array}$ & $\begin{array}{c}-0.043 * * * \\
(-4.070)\end{array}$ & $\begin{array}{l}-0.028 * * * \\
(-2.556)\end{array}$ & $\begin{array}{l}-0.046 * * * \\
(-4.340)\end{array}$ & $\begin{array}{l}-0.037 * * * \\
(-3.551)\end{array}$ \\
\hline POSTxTREATxDISCVARxDRISK & - & & $\begin{array}{l}-0.247 * * * \\
(-5.758)\end{array}$ & $\begin{array}{c}-0.440 * * * \\
(-6.517)\end{array}$ & $\begin{array}{l}-0.002 * * \\
(-1.744)\end{array}$ & $\begin{array}{l}-0.001 * * * \\
(-4.041)\end{array}$ & $\begin{array}{c}-0.003 * \\
(-1.485)\end{array}$ & $\begin{array}{l}-0.048 * * * \\
(-7.190)\end{array}$ \\
\hline ROA & - & $\begin{array}{l}-0.360 * * * \\
(-3.750)\end{array}$ & $\begin{array}{l}-0.358 \text { *** } \\
(-3.741)\end{array}$ & $\begin{array}{l}-0.365 \text { *** } \\
(-3.804)\end{array}$ & $\begin{array}{c}-0.359 \text { *** } \\
(-3.750)\end{array}$ & $\begin{array}{l}-0.360 \text { *** } \\
(-3.771)\end{array}$ & $\begin{array}{l}-0.362 * * * \\
(-3.773)\end{array}$ & $\begin{array}{l}-0.362 * * * \\
(-3.786)\end{array}$ \\
\hline LEV & + & $\begin{array}{c}0.491 \text { *** } \\
(11.968)\end{array}$ & $\begin{array}{l}0.492 \text { *** } \\
(12.029)\end{array}$ & $\begin{array}{l}0.492{ }^{* * *} \\
(11.998)\end{array}$ & $\begin{array}{l}0.490 \text { *** } \\
(11.949)\end{array}$ & $\begin{array}{l}0.490 \text { *** } \\
(11.987)\end{array}$ & $\begin{array}{l}0.4911^{* * *} \\
(11.991)\end{array}$ & $\begin{array}{l}0.492 \text { *** } \\
(12.032)\end{array}$ \\
\hline BTM & + & $\begin{array}{l}0.187 \text { *** } \\
(22.038)\end{array}$ & $\begin{array}{l}0.186 \text { *** } \\
(21.978)\end{array}$ & $\begin{array}{l}0.187 \text { *** } \\
(22.047)\end{array}$ & $\begin{array}{l}0.187 \text { *** } \\
(22.027)\end{array}$ & $\begin{array}{l}0.187 \text { *** } \\
(22.035)\end{array}$ & $\begin{array}{l}0.187 \text { *** } \\
(22.069)\end{array}$ & $\begin{array}{l}0.186 \text { *** } \\
(22.009)\end{array}$ \\
\hline SIZE & - & $\begin{array}{c}-0.229 \text { *** } \\
(-26.841)\end{array}$ & $\begin{array}{l}-0.227 \text { *** } \\
(-26.748)\end{array}$ & $\begin{array}{c}-0.228 \text { *** } \\
(-26.792)\end{array}$ & $\begin{array}{c}-0.228 \text { *** } \\
(-26.727)\end{array}$ & $\begin{array}{l}-0.229 \text { *** } \\
(-26.900)\end{array}$ & $\begin{array}{c}-0.229 \text { *** } \\
(-26.855)\end{array}$ & $\begin{array}{c}-0.227 \text { *** } \\
(-26.808)\end{array}$ \\
\hline PRICE & - & $\begin{array}{l}-0.006 \text { *** } \\
(-7.942)\end{array}$ & $\begin{array}{l}-0.006 \text { *** } \\
(-7.891)\end{array}$ & $\begin{array}{l}-0.006 \text { *** } \\
(-7.900)\end{array}$ & $\begin{array}{l}-0.006 \text { *** } \\
(-7.959)\end{array}$ & $\begin{array}{l}-0.006 \text { *** } \\
(-7.929)\end{array}$ & $\begin{array}{l}-0.006 \text { *** } \\
(-7.942)\end{array}$ & $\begin{array}{l}-0.006 \text { *** } \\
(-7.883)\end{array}$ \\
\hline TURNOVER & - & $\begin{array}{l}-0.316 \text { *** } \\
(-60.565)\end{array}$ & 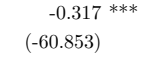 & $\begin{array}{l}-0.317 \text { *** } \\
(-60.763)\end{array}$ & $\begin{array}{l}-0.316 \text { *** } \\
(-60.556)\end{array}$ & $\begin{array}{l}-0.316 \text { *** } \\
(-60.707)\end{array}$ & $\begin{array}{l}-0.316 \text { *** } \\
(-60.540)\end{array}$ & $\begin{array}{l}-0.317 \text { *** } \\
(-60.919)\end{array}$ \\
\hline FOLLOW & - & $\begin{array}{c}-0.213 \text { *** } \\
(-16.341)\end{array}$ & $\begin{array}{c}-0.213 \text { *** } \\
(-16.331)\end{array}$ & $\begin{array}{c}-0.213 * * * \\
(-16.325)\end{array}$ & $\begin{array}{c}-0.213 \text { *** } \\
(-16.351)\end{array}$ & $\begin{array}{l}-0.213 \text { *** } \\
(-16.326)\end{array}$ & $\begin{array}{c}-0.213 * * * \\
(-16.337)\end{array}$ & $\begin{array}{c}-0.213 \text { *** } \\
(-16.318)\end{array}$ \\
\hline PREDERIV & & $\begin{array}{r}0.042 \\
(1.233)\end{array}$ & $\begin{array}{c}0.054 * \\
(1.598)\end{array}$ & $\begin{array}{l}0.066 \text { ** } \\
(1.950)\end{array}$ & $\begin{array}{r}0.044 \\
(1.308)\end{array}$ & $\begin{array}{r}0.048 \\
(1.427)\end{array}$ & $\begin{array}{r}0.043 \\
(1.261)\end{array}$ & $\begin{array}{l}0.064{ }^{* *} \\
(1.916)\end{array}$ \\
\hline PASTSTDRET & + & $\begin{array}{c}6.746 \text { *** } \\
(26.614)\end{array}$ & $\begin{array}{l}6.739 \text { *** } \\
(26.674)\end{array}$ & $\begin{array}{l}6.725 \text { *** } \\
(26.665)\end{array}$ & $\begin{array}{l}6.744 \text { *** } \\
(26.637)\end{array}$ & $\begin{array}{l}6.732 * * * \\
(26.580)\end{array}$ & $\begin{array}{l}6.743 \text { *** } \\
(26.618)\end{array}$ & $\begin{array}{c}\quad 6.724 \text { **** } \\
(26.661)\end{array}$ \\
\hline TRADESIZE & + & $\begin{array}{c}0.0011^{* * *} \\
(37.011)\end{array}$ & $\begin{array}{c}0.001 \text { *** } \\
(37.049) \\
\end{array}$ & $\begin{array}{c}0.001{ }^{* * *} \\
(37.114) \\
\end{array}$ & $\begin{array}{c}0.001 \text { *** } \\
(36.970) \\
\end{array}$ & $\begin{array}{c}0.001 \text { *** } \\
(37.017) \\
\end{array}$ & $\begin{array}{c}0.001{ }^{* * *} \\
(37.026) \\
\end{array}$ & $\begin{array}{c}0.0011^{* * *} \\
(37.092) \\
\end{array}$ \\
\hline $\begin{array}{l}\text { Industry fixed effects } \\
\end{array}$ & & Yes & Yes & Yes & Yes & Yes & Yes & Yes \\
\hline $\begin{array}{l}\mathrm{N} \\
\text { Adj. R2 }\end{array}$ & & $\begin{array}{r}1075113 \\
0.696\end{array}$ & $\begin{array}{r}1075113 \\
0.696\end{array}$ & $\begin{array}{r}1075113 \\
0.696\end{array}$ & $\begin{array}{r}1075113 \\
0.696\end{array}$ & $\begin{array}{r}1075113 \\
0.696\end{array}$ & $\begin{array}{r}1075113 \\
0.696\end{array}$ & $\begin{array}{r}1075113 \\
0.696\end{array}$ \\
\hline
\end{tabular}

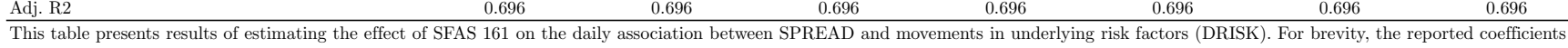
on DRISK, POSTXDRISK, POSTXTREATXDRISK, and POSTxTREATxDISCVARxDRISK are aggregated across days $t-1, t$, and $t+1$. The control variables are similar to those in Panel $A$ of Table C.5 except that PRICE, TURNOVER, and TRADESIZE are measured daily (instead of taking averages). The remaining control variables are measured as of the previous fiscal quarter end relative to each firm-day Standard errors are heteroskedasticity-robust and clustered by firm. $t$-statistics are reported in parentheses, and statistical significance based on one-tailed tests for variables with predicted signs (two-tailed otherwise) is indicated by * for $p<0.10$; ** for $p<0.05$; and ${ }^{* * *}$ for $p<0.01$ 
Table C.9

Replication of Tables C.6, C.7, and C.8 Including MD\&A Disclosure Characteristics

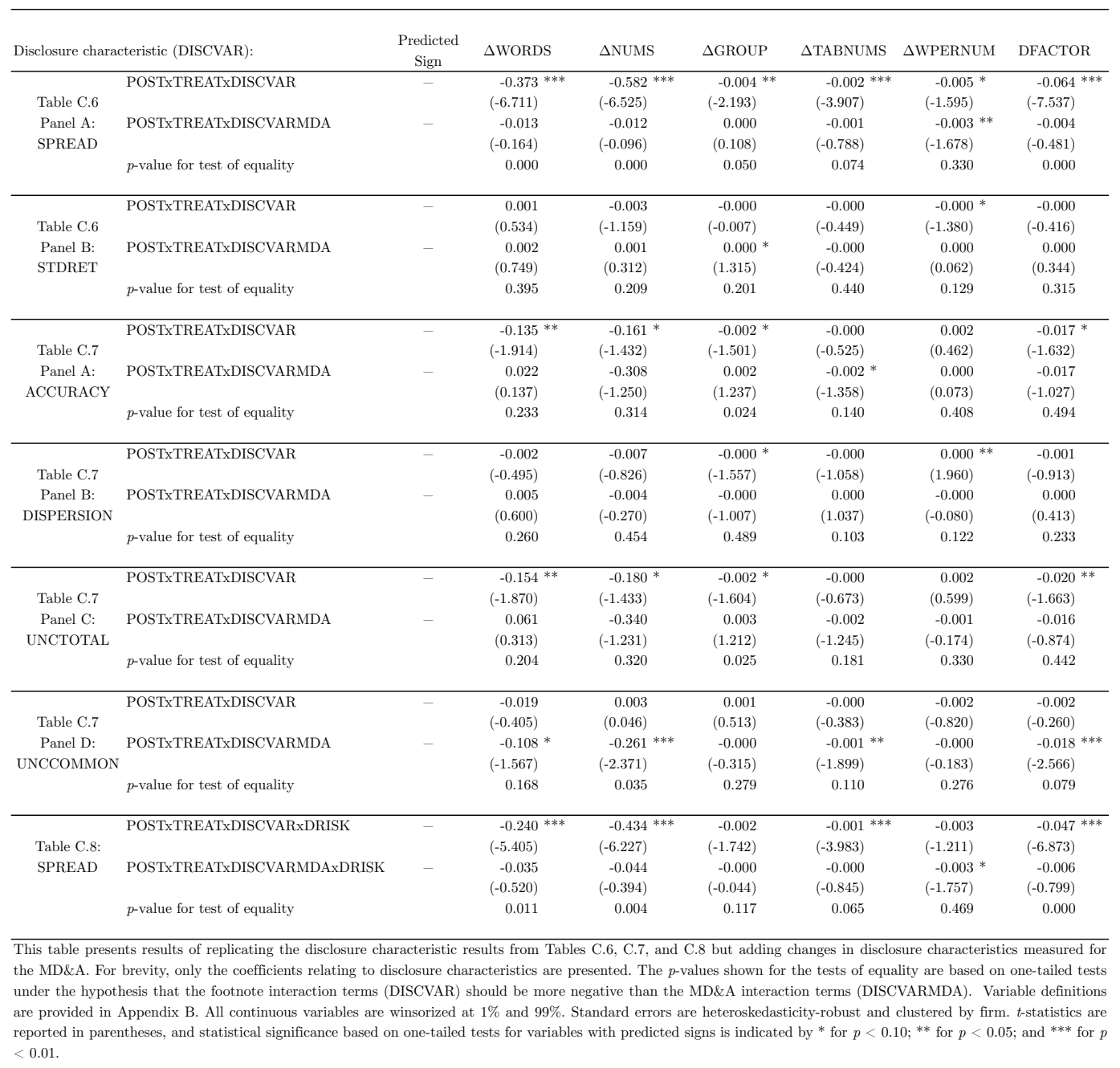




\section{Bibliography}

Ahmed, A., Kilic, E., and Lobo, G. (2006), "Does recognition versus disclosure matter? Evidence from value-relevance of banks' recognized and disclosed derivative financial instruments," The Accounting Review, 81, 567-588.

Ahmed, A., Kilic, E., and Lobo, G. (2011), "Effects of SFAS 133 on the risk relevance of accounting measures of banks' derivative exposures," The Accounting Review, $86,769-804$.

Allayannis, G. and Weston, J. P. (2001), "The use of foreign currency derivatives and firm market value," Review of Financial Studies, 14, 243-276.

Allee, K. D. and DeAngelis, M. D. (2015), "The structure of voluntary disclosure narratives: Evidence from tone dispersion," Journal of Accounting Research, 53, $241-274$.

Bank for International Settlements (BIS) (2009), OTC Derivatives Market Activity in the First Half of 2009, Bank for International Settlements.

Bank for International Settlements (BIS) (2015), BIS Statistical Bulletin, September 2015, Bank for International Settlements.

Bao, Y. and Datta, A. (2014), "Simultaneously discovering and quantifying risk types from textual risk disclosures," Management Science, 60, 1371-1391.

Barron, O. E., Kim, O., Lim, S. C., and Stevens, D. E. (1998), "Using analysts' forecasts to measure properties of analysts' information environment," The Accounting Review, 73, 421-433.

Barth, M., Beaver, W., and Landsman, W. (1996), "Value-relevance of banks' fair value disclosures under SFAS No. 107," The Accounting Review, 71, 513-537.

Bens, D., Cheng, M., and Neamtiu, M. (2015), "The impact of SEC disclosure monitoring on the uncertainty of fair value estimates," forthcoming, The Accounting Review.

Bloomfield, R., Hodge, F., Hopkins, P., and Rennekamp, K. (2015), "Does coordinated presentation help credit analysts identify firm characteristics?" Contemporary Accounting Research, 32, 507-527. 
Burkholder, S. (2014), "FASB to Start Project on Simplifying, Easing Derivatives and Hedge Accounting," http://www.bna.com/fasb-start-project-n17179911436/.

Campbell, J. L., Chen, H., Dhaliwal, D. S., Lu, H.-m., and Steele, L. B. (2014), "The information content of mandatory risk factor disclosures in corporate filings," Review of Accounting Studies, 19, 396-455.

Chang, H. S., Donohoe, M., and Sougiannis, T. (2015), "Do analysts understand the economic and reporting complexities of derivatives?" forthcoming, Journal of Accounting and Economics.

Ciesielski, J. T. (2008), "Credit derivatives disinfectant: First rays of sunshine," The Analyst's Accounting Observer, 17, 1-6.

Cowins, E. (2014), "Does hedge accounting reflect firms' risk management activities?" Working paper: Georgia State University.

DeMarzo, P. M. and Duffie, D. (1991), "Corporate financial hedging with proprietary information," Journal of Economic Theory, 53, 261-286.

DeMarzo, P. M. and Duffie, D. (1995), "Corporate incentives for hedging and hedge accounting," Review of Financial Studies, 8, 743-771.

Eccher, E., Ramesh, K., and Thiagarajan, S. (1996), "Fair value disclosures by bank holding companies," Journal of Accounting and Economics, 22, 79-117.

Filzen, J. (2015), "The information content of risk factor disclosures in quarterly reports," forthcoming, Accounting Horizons.

Financial Accounting Standards Board (FASB) (2008), Disclosures about Derivative Instruments and Hedging Activities, Statement of Financial Accounting Standards No. 161, FASB, Norwalk, CT.

Financial Accounting Standards Board (FASB) (2010), Statement of Financial Accounting Concepts No. 8: Conceptual Framework for Financial Reporting, FASB, Norwalk, CT.

Financial Accounting Standards Board (FASB) (2012), Discussion Paper: Disclosure Framework, Financial Accounting Foundation, Norwalk, CT.

Financial Accounting Standards Board (FASB) (2014), Exposure Draft: Proposed Statement of Financial Accounting Concepts: Conceptual Framework for Financial Reporting: Chapter 8: Notes to Financial Statements, Financial Accounting Foundation, Norwalk, CT.

Gallo, L. (2013), "The more we know about fundamentals, the less we agree on price? Evidence from earnings announcements," working paper: University of Michigan. 
Géczy, C., Minton, B., and Schrand, C. (1997), "Why firms use currency derivatives," The Journal of Finance, 52, 1323-1354.

Guay, W. (1999), "The impact of derivatives on firm risk: An empirical examination of new derivative users," Journal of Accounting and Economics, 26, 319-351.

Heflin, F., Moon, J. R., and Wallace, D. (2015), "A re-examination of the cost of capital benefits from higher quality disclosures," forthcoming, Journal of Financial Reporting.

Hirst, D. E. and Hopkins, P. E. (1998), "Comprehensive income reporting and analysts' valuation judgments," Journal of Accounting Research, 36, 47-75.

Holthausen, D. M. (1979), "Hedging and the competitive firm under price uncertainty," The American Economic Review, 69, 989-995.

Holthausen, R. W. and Verrecchia, R. E. (1990), "The effect of informedness and consensus on price and volume behavior," The Accounting Review, 65, 191-208.

Hope, O.-K., Hu, D., and Lu, H. (2015), "The benefits of specific risk-factor disclosures," working paper: University of Toronto.

Hull, J. C. (2012), Options, Futures, and Other Derivatives, Prentice Hall, Boston, MA, 8th edn.

International Accounting Standards Board (IASB) (2013), Discussion Paper: A Review of the Conceptual Framework for Financial Reporting, IFRS Foundation, London, United Kingdom.

Khan, U., Li, B., Rajgopal, S., and Venkatachalam, M. (2015), "Do the FASB's standards add (shareholder) value?" working paper: Columbia University, University of Texas at Dallas, and Duke University.

Kondor, P. (2012), "The more we know about the fundamental, the less we agree on the price," Review of Economic Studies, 79, 1175-1207.

Koonce, L., Lipe, M., and McAnally, M. (2005), "Judging the risk of financial instruments: Problems and potential remedies," The Accounting Review, 80, 871-895.

Koonce, L., Lipe, M., and McAnally, M. (2008), "Investor reactions to derivative use and outcomes," Review of Accounting Studies, 13, 571-597.

Kravet, T. and Muslu, V. (2013), "Textual risk disclosures and investors' risk perceptions," Review of Accounting Studies, 18, 1088-1122.

Lawrence, A. (2013), "Individual investors and financial disclosure," Journal of Accounting and Economics, 56, 130-147. 
Lehavy, R., Li, F., and Merkley, K. (2011), "The effect of annual report readability on analyst following and the properties of their earnings forecasts," The Accounting Review, 86, 1087-1115.

Leuz, C. and Verrecchia, R. E. (2000), "The economic consequences of increased disclosure," Journal of Accounting Research, 38, 91-124.

Li, F. (2008), "Annual report readability, current earnings, and earnings persistence," Journal of Accounting and Economics, 45, 221-247.

Linsmeier, T., Thornton, D., Venkatachalam, M., and Welker, M. (2002), "The effect of mandated market risk disclosures on trading volume sensitivity to interest rate, exchange rate, and commodity price movements," The Accounting Review, 77, $343-377$.

Loughran, T. and McDonald, B. (2014), "Measuring readability in financial disclosures," The Journal of Finance, 69, 1643-1671.

Maines, L. and McDaniel, L. (2000), "Effects of comprehensive-income characteristics on nonprofessional investors' judgments: The role of financial-statement presentation format," The Accounting Review, 75, 179-207.

Manchiraju, H., Pierce, S., and Sridharan, S. (2014), "Do firms use derivatives for hedging or non-hedging purposes? Evidence based on SFAS 161 disclosures," working paper: Indian School of Business, Florida State University, and Northwestern University.

McAnally, M. (1996), "Banks, risk, and FAS105 disclosures," Journal of Accounting, Auditing \& Finance, 11, 453-490.

Miller, B. P. (2010), "The effects of reporting complexity on small and large investor trading," The Accounting Review, 85, 2107-2143.

Nelson, K. (1996), "Fair value accounting for commercial banks: An empirical analysis of SFAS No. 107," The Accounting Review, 71, 161-182.

Panaretou, A., Shackleton, M., and Taylor, P. (2013), "Corporate risk management and hedge accounting," Contemporary Accounting Research, 30, 116-139.

Pastor, L. and Veronesi, P. (2003), "Stock valuation and learning about profitability," The Journal of Finance, 58, 1749-1790.

Pérez-González, F. and Yun, H. (2013), "Risk management and firm value: Evidence from weather derivatives," The Journal of Finance, 68, 2143-2176.

Pierce, S. (2015), "Does the accounting for derivatives affect risk and value?" working paper: Florida State University. 
Rajgopal, S. and Venkatachalam, M. (2011), "Financial reporting quality and idiosyncratic return volatility," Journal of Accounting and Economics, 51, 1-20.

Rennekamp, K. (2012), "Processing fluency and investors' reactions to disclosure readability," Journal of Accounting Research, 50, 1319-1354.

Schrand, C. (1997), "The association between stock-price interest rate sensitivity and disclosures about derivative instruments," The Accounting Review, 72, 87-109.

Stulz, R. M. (1984), "Optimal hedging policies," Journal of Financial and Quantitative Analysis, 19, 127-140.

Tufano, P. (1996), "Who manages risk? An empirical examination of risk management practices in the gold mining industry," The Journal of Finance, 51, 10971137.

Venkatachalam, M. (1996), "Value-relevance of banks' derivatives disclosures," Journal of Accounting and Economics, 22, 327-355.

Wong, M. H. F. (2000), "The association between SFAS No. 119 derivatives disclosures and the foreign exchange risk exposure of manufacturing firms," Journal of Accounting Research, 38, 387-417.

Zhang, H. (2009), "Effect of derivative accounting rules on corporate riskmanagement behavior," Journal of Accounting and Economics, 47, 244-264.

Zhang, X. F. (2006), "Information uncertainty and stock returns," The Journal of Finance, 61, 105-137.

Zou, Y. (2012), "Strategic entry decisions, accounting signals, and risk management disclosure," working paper: The George Washington University. 


\section{Biography}

Thomas DeVoe Steffen was raised in Las Vegas, Nevada. He graduated from Brigham Young University in 2010 after earning a bachelor's degree in accounting and economics and a master's degree in accounting. While at Brigham Young University, he was also a member of the BYU Accounting Ph.D. Prep Track. During his doctoral studies at Duke University, Thomas received a graduate fellowship from the Kenan Institute for Ethics at Duke University, was awarded the Best Second-year Doctoral Student Paper by the American Accounting Association's Southeast Region, and received a Deloitte Foundation Doctoral Fellowship. For his work on CEO integrity, Thomas received the Glen McLaughlin Prize for Research in Accounting Ethics with his coauthors Shane Dikolli and Bill Mayew. His first faculty position will be as an assistant professor of accounting at the Yale University School of Management. 